\title{
Immunoproteasome inhibitor-doxorubicin conjugates target Multiple Myeloma cells and release Doxorubicin upon low-dose photon irradiation.
}

Elmer Maurits $^{[\mathrm{a}] \ddagger}$, Michel J. van de Graaff ${ }^{[\mathrm{a}] \ddagger}$, Santina Maiorana ${ }^{[\mathrm{b}]}$, Dennis P. A. Wander ${ }^{[\mathrm{a}]}$, Patrick M. Dekker $^{[\mathrm{a}]}$, Sabina Y. van der Zanden ${ }^{[\mathrm{c}]}$, Bogdan I. Florea ${ }^{[\mathrm{a}]}$, Jacques J. C. Neefjes ${ }^{[\mathrm{c}]}$, Herman S.

Overkleeft $^{[\mathrm{a}]^{*}}$, Sander I. van Kasteren ${ }^{[\mathrm{a}]^{*}}$

[a] Gorlaeus Laboratories, Leiden Institute of Chemistry, Leiden University, Leiden, The Netherlands

[b] Department of Chemical, Biological, Pharmaceutical and Environmental Sciences, University of Messina, Messina, Italy

[c] Leiden University Medical Center, ONCODE Institute, Leiden, The Netherlands

\begin{abstract}
Proteasome inhibitors are established therapeutic agents for the treatment of hematological cancers, as for anthracyclines such as doxorubicin. We here present a new drug targeting approach that combines both drug classes into a single molecule. Doxorubicin was conjugated to an immunoproteasome-selective inhibitor via light-cleavable linkers, yielding peptide epoxyketone-doxorubicin prodrugs that remained selective and active towards immunoproteasomes. Upon cellular uptake and immunoproteasome inhibition, doxorubicin is released from the immunoproteasome inhibitor through photo-irradiation. Multiple myeloma cells in this way take a double hit: immunoproteasome inhibition and doxorubicin-induced toxicity. Our strategy, which entails targeting of a cytotoxic agent, through a covalent enzyme inhibitor that is detrimental to tumor tissue in its own right, may find use in the search for improved anticancer drugs.
\end{abstract}




\section{Table of Contents}

1. Supporting Figures

2. Biochemical methods

3. Synthetic Procedures

S13

A) Synthesis of bis-functionalized NPBF-based photoprotecting group

B) Synthesis of bis-functionalized ortho-nitrobenzoyl photoprotecting group

C) Synthesis cyclohexylamine warhead

S20

D) Synthesis of LU-035i

S20

E) Synthesis of conjugates 1 and 2

S25

F) Synthesis of control compound NPBF-Doxo

$4 \quad$ References

5. ${ }^{1} \mathrm{H}-\mathrm{NMR}$ and ${ }^{13} \mathrm{C}-\mathrm{NMR}$ APT spectra

S29

6. LC-MS Spectra 


\section{Supporting Figures}

1

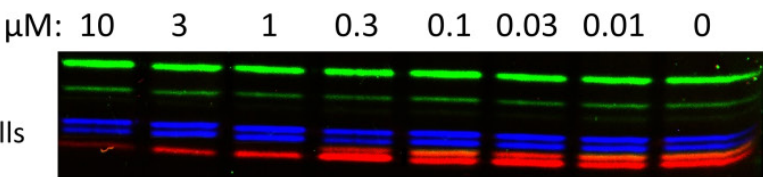

AMO-1 cells

AMO-1 lysate

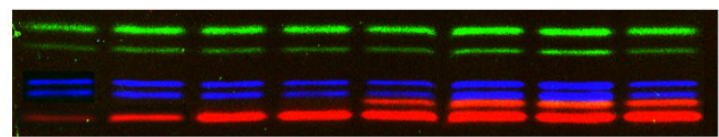

2
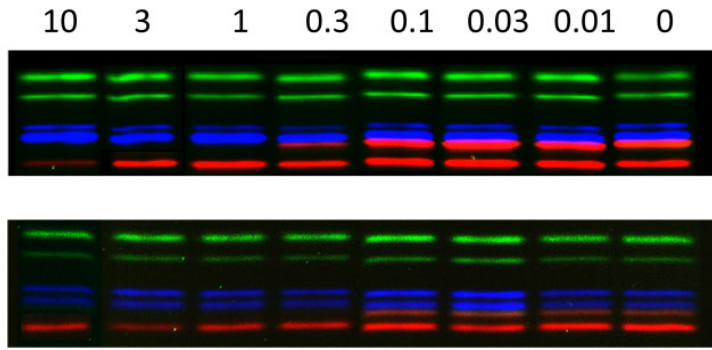

Figure S1. Competitive ABPP of compounds 1 and 2 with established proteasome subunit-selective activity based probes in AMO-1 cells and lysates. Cells (top) or lysates (bottom) were treated with the conjugate for $1 \mathrm{~h}$, followed by washing of the cells, lysis and incubation of the ABP cocktail described in Figure S3.

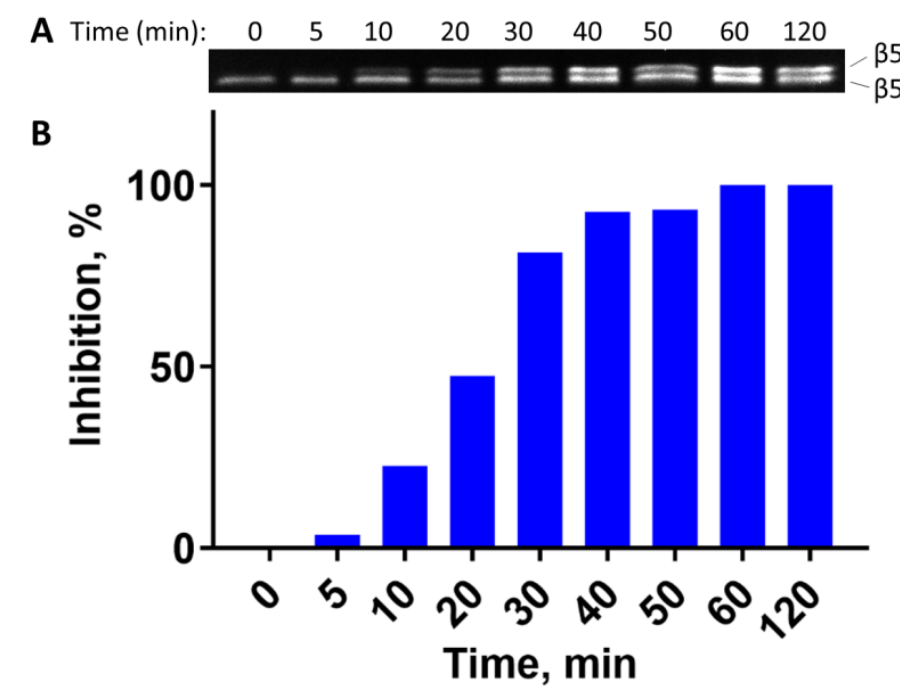

Figure S2. Cell permeability determination by ABPP on AMO-1 cells. A) SDS-PAGE gel separation of competitive ABPP with compound 1 and established proteasome subunit-selective activity based probes. B) Plotted data of SDS-PAGE gel $\beta 5 i$ band intensity. Conditions: Cells were treated with compound 1 for the indicated time points followed by washing of the cells, lysis and incubation of the ABP cocktail described in Figure S3.
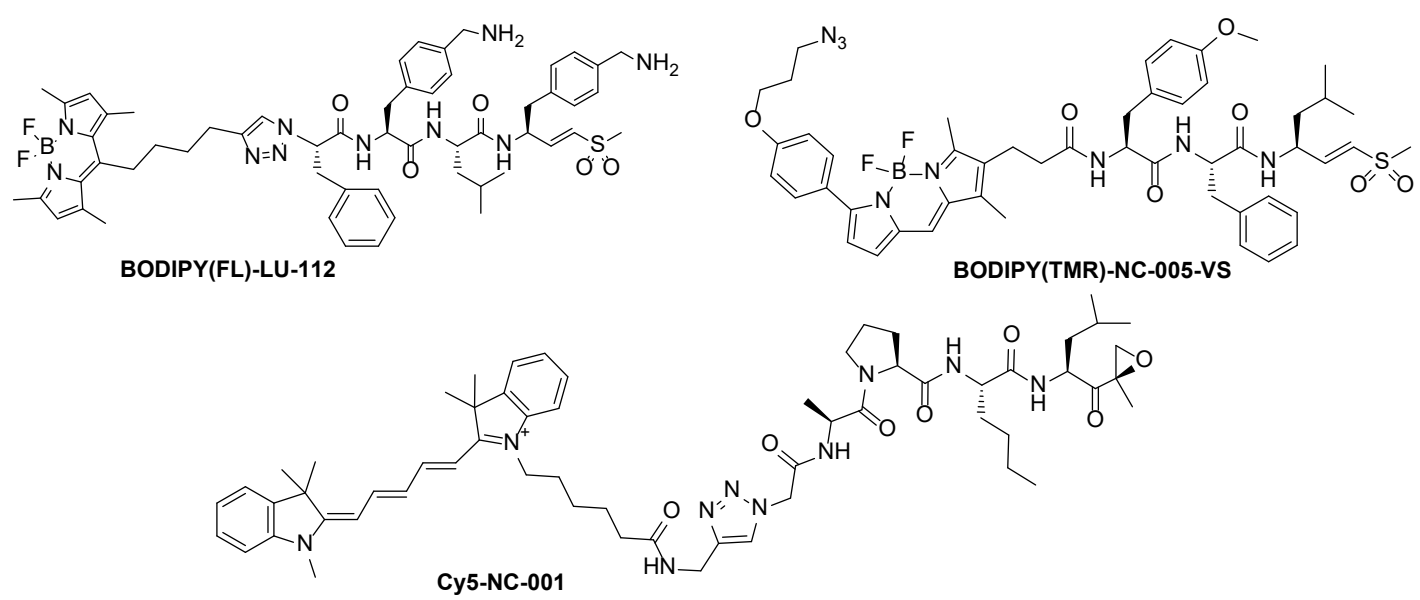

Figure S3. Structures of ABP cocktail used for labeling the proteasome subunits in cell lysates. BODIPY(FL)-LU-112 labels the $\beta 2 \mathrm{c} / \mathrm{i}$ subunits with a green color, BODIPY(TMR)-NC-005-VS labels the $\beta 5 \mathrm{c} / \mathrm{l}$ subunits with a red color and Cy5-NC-001 labels the $\beta 1 \mathrm{c} / \mathrm{i}$ subunits with a blue color. 


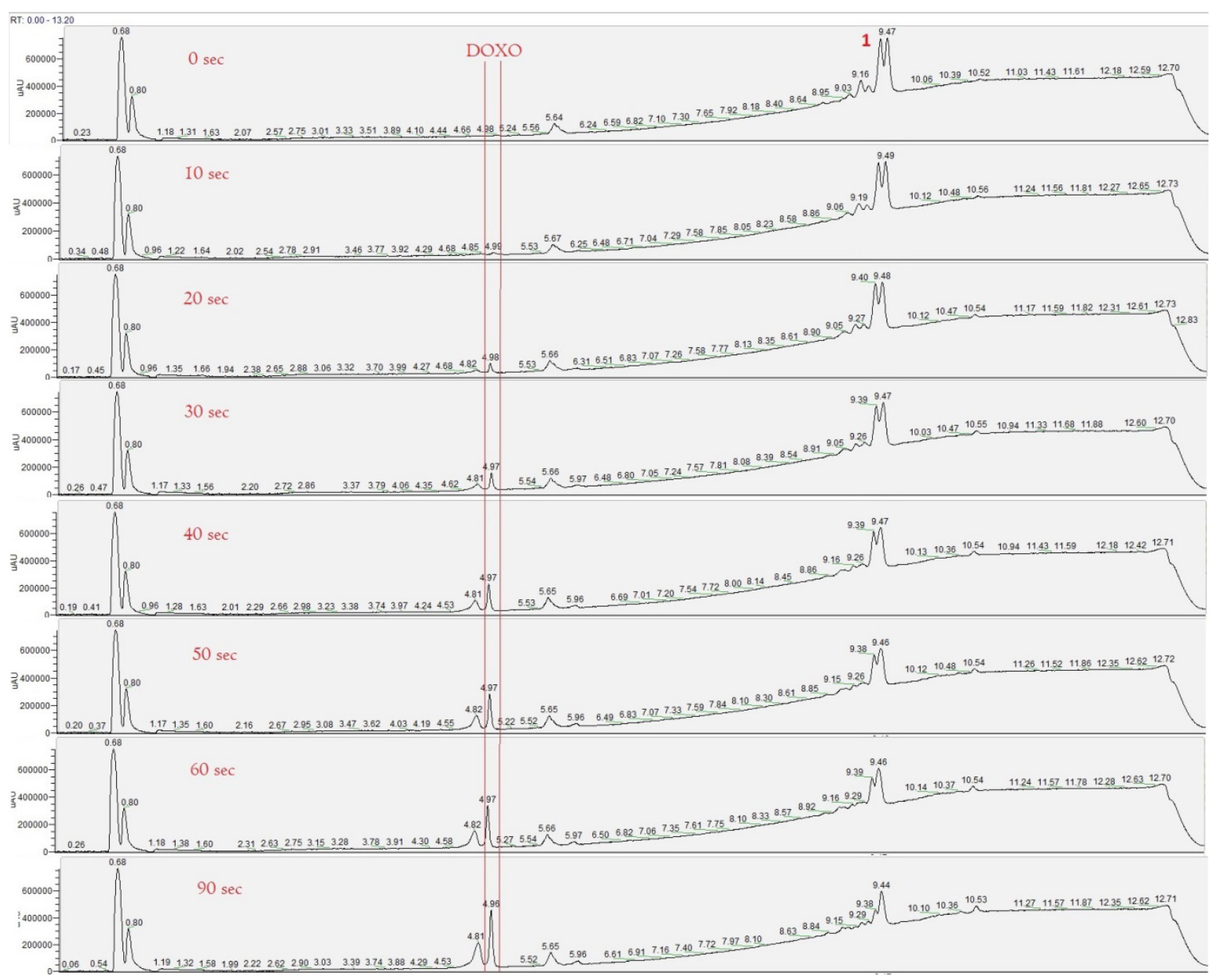

Figure S4. LC-MS spectra of compound 1 after over time irradiation at $375 \mathrm{~nm}$ at defined times in a mixture of 1:1:1 acetonitrile:t-BuOH: $\mathrm{H}_{2} \mathrm{O}$ indicating doxorubicin (Doxo) release at $\mathrm{RT}=4.97$ and 4.81. $\mathrm{RT}$ of compound $1=9.38$ and 9.47 , $\mathrm{RT}$ of decayed product of $1=9.44$.
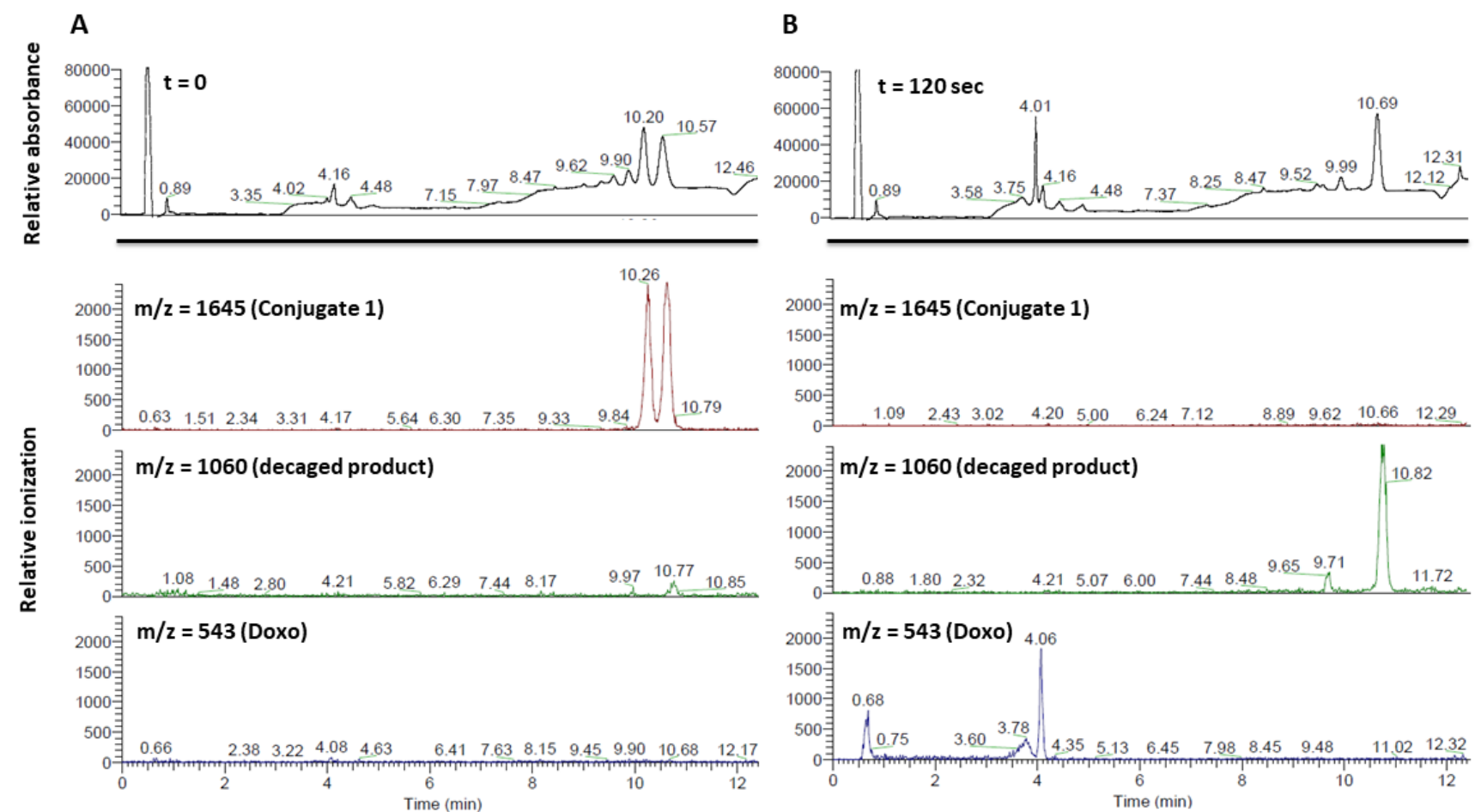

Figure S5. LC-MS spectra of compound 1 after over time irradiation at $375 \mathrm{~nm}$ at defined times in a mixture of 1:1:1 acetonitrile: $t-\mathrm{BuOH}: \mathrm{H}_{2} \mathrm{O}$. A) $\left.\mathrm{t}=0 ; \mathbf{B}\right) \mathrm{t}=120 \mathrm{sec}$. 


\section{Photochemical characterization}

The photochemical properties of the newly functionalized cage were determined. An NPBF-protected lysine was produced, either unmodified at the 5-position (22), or functionalized with a 2-oxo-tert-butyl acetate (20) or 2-oxo-propargyl (21). Functionalization increased the $\varepsilon$ for both substitutions at $365 \mathrm{~nm}$ by $30 \%$ to $17^{*} 10^{3} \mathrm{M}^{-1} \mathrm{~cm}^{-1}$ when compared to unsubstituted NPBF $\left(\varepsilon=13^{*} 10^{3} \mathrm{M}^{-1} \mathrm{~cm}^{-}\right.$ $\left.{ }^{1}\right)$, as determined by UV-Vis.

The release kinetics of the NPBF and oNB linkers were determined at $375 \mathrm{~nm}$ or $420 \mathrm{~nm}$. A UV-Vis analysis was taken after different irradiation times, with the irradiation setup used as depicted in Figure S4, under continuous stirring in a mixture of 1:1:1 acetonitrile:t$\mathrm{BuOH}: \mathrm{H}_{2} \mathrm{O}$. Assuming pseudo-first order reaction kinetics, a relative reaction rate constant was calculated (Figure S6A) for conjugates 1 and 2 in comparison to non-functionalized compound 21 by quantifying the absorbance reduction as a function of irradiation time at $\lambda^{\max }$ of the starting material (Figure S6). The effect of aromatic substitution on the reaction rate was determined by comparing non-functionalized NPBF-caged lysine (22) with two functionalized caged lysines (20, 21, Figure S6B). The reaction rate of conjugate 2 (and derivative 45 ) was considered too low and was discarded for further experiments.

A

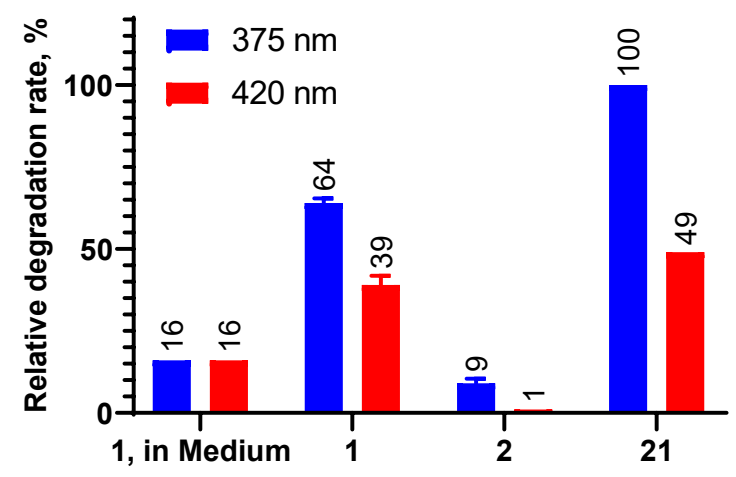

\section{B Relative degradation rates}

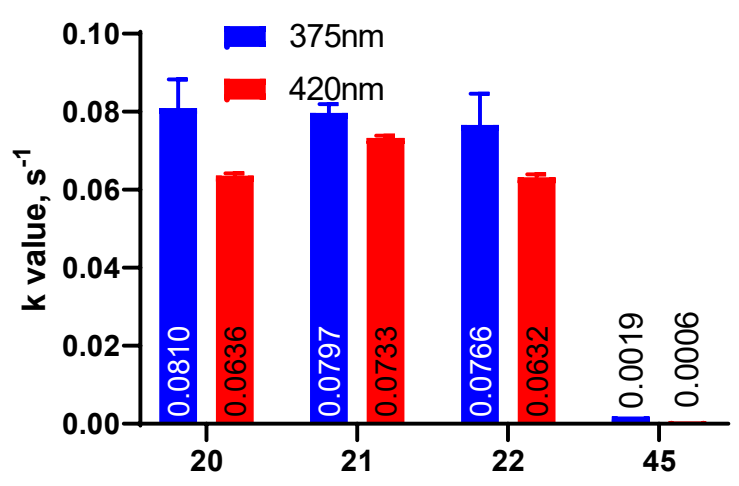

C

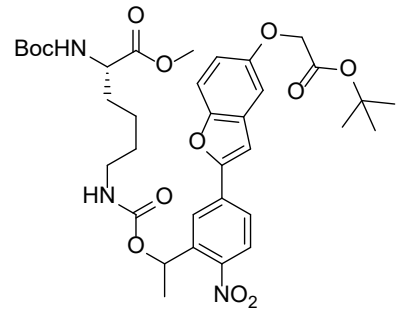

20

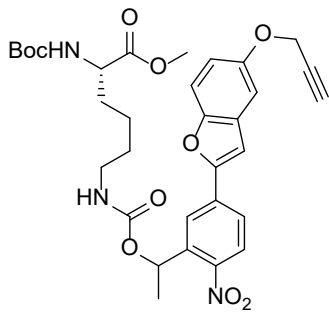

21

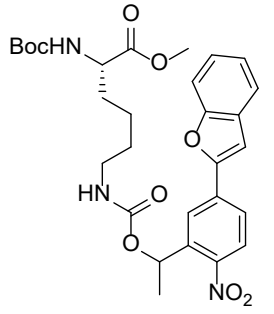

22

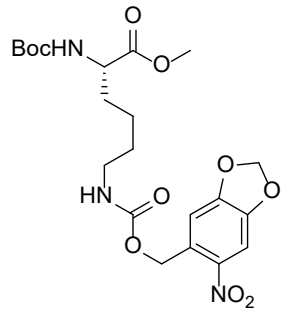

45

Figure S6. A) Relative degradation rates of conjugates 1 and 2 at $375 \mathrm{~nm}$ and $420 \mathrm{~nm}$ as a percentage of compound 21. B) Degradation rates calculated for compounds 20, 21, 22 and 45. C) Structures of compounds 20, 21, 22 and 45. 
1, $420 \mathrm{~nm}$

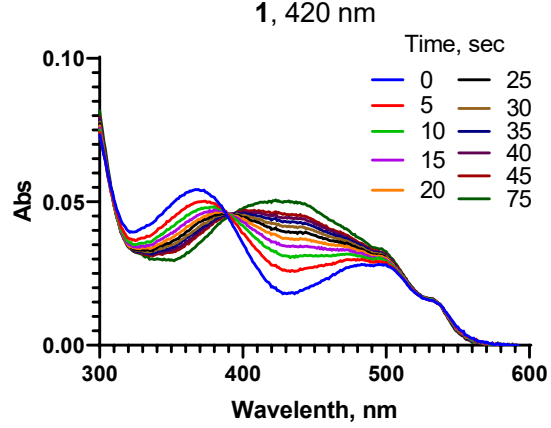

$2,420 \mathrm{~nm}$

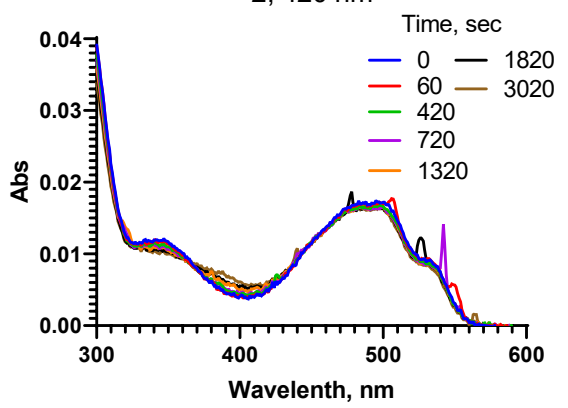

$1,420 \mathrm{~nm}$ in medium

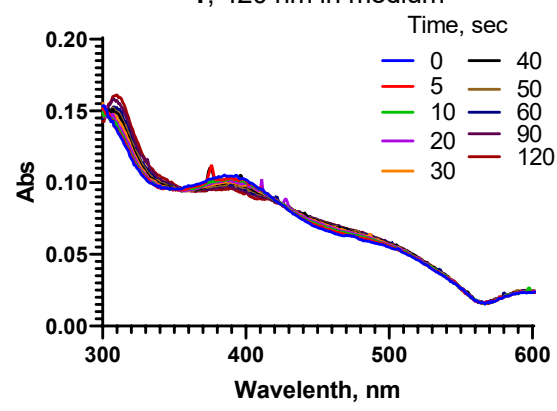

Medium $420 \mathrm{~nm}$

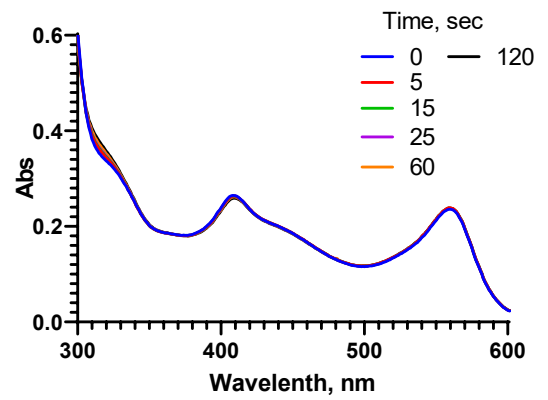

21, $420 \mathrm{~nm}$

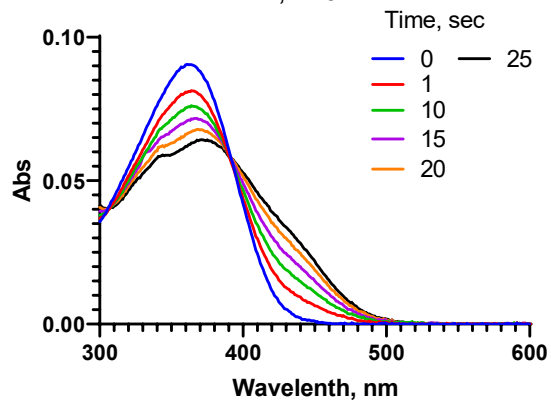

1, $375 \mathrm{~nm}$

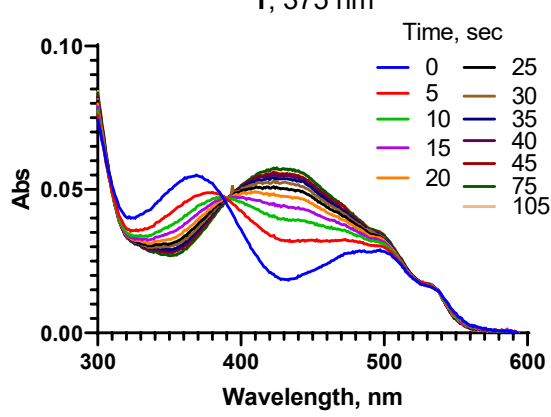

2, $375 \mathrm{~nm}$

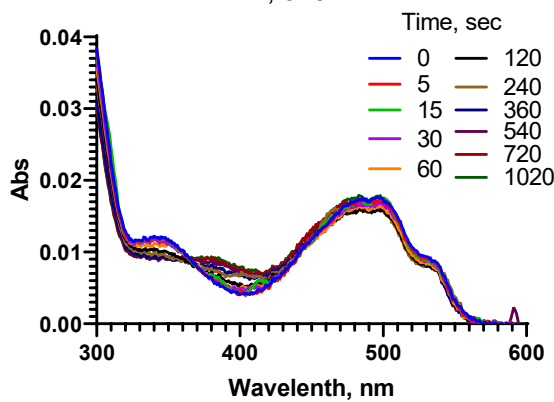

$1,375 \mathrm{~nm}$ in medium

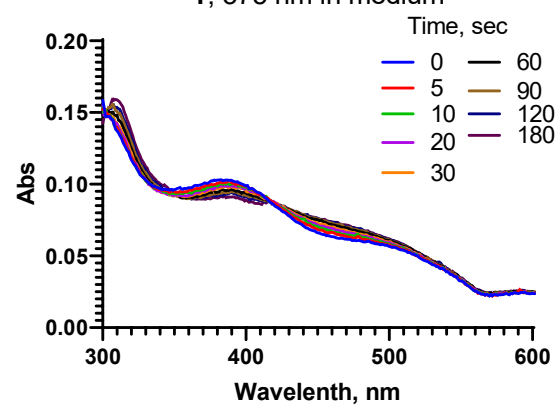

Medium $375 \mathrm{~nm}$

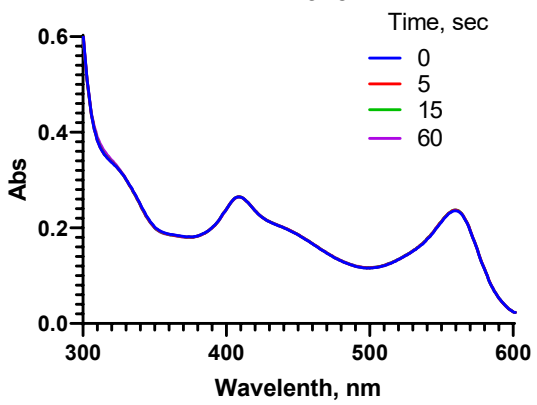

21, $375 \mathrm{~nm}$

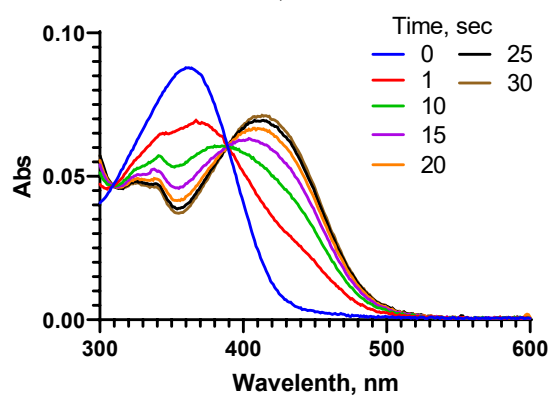

Figure S7. Absorption spectra measured over time after irradiation at $375 \mathrm{~nm}$ or $420 \mathrm{~nm}$ at defined times in a mixture of $1: 1: 1$ acetonitrile:t-BuOH: $\mathrm{H}_{2} \mathrm{O}$ under continuous stirring. 


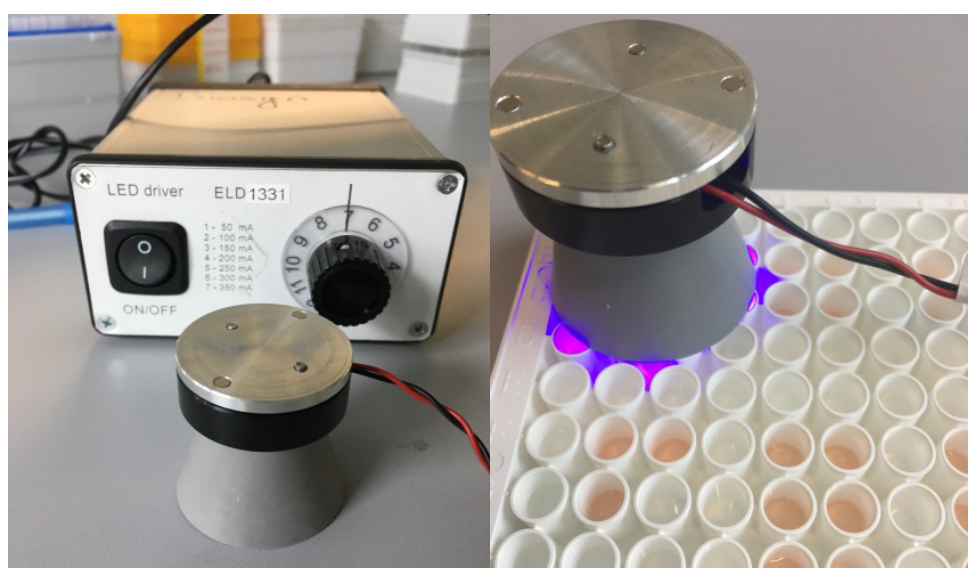

Figure S8. Irradiation setup. A LED (Roithner Lasertechnik, High Power Single Chip LEDs, Hexagonal Package, H2A1 series; 375 $\mathrm{nm}: 3 \mathrm{~mW} / \mathrm{cm}^{2}, 200 \mathrm{~mW}$ output power, $350 \mathrm{~mA}$ current, $3.7 \mathrm{~V} ; 420 \mathrm{~nm}: 13 \mathrm{~mW} / \mathrm{cm}^{2}, 130 \mathrm{~mW}$ output power, $350 \mathrm{~mA}$ current, $3.5 \mathrm{~V}$ ) was mounted on a aluminum heat sink and connected to an adaptor. Wells were irradiated from a distance of approx. $3 \mathrm{~cm}$.

A

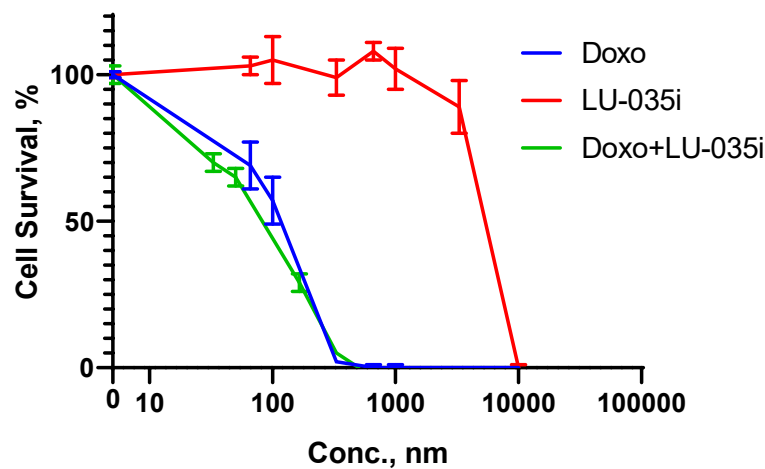

B

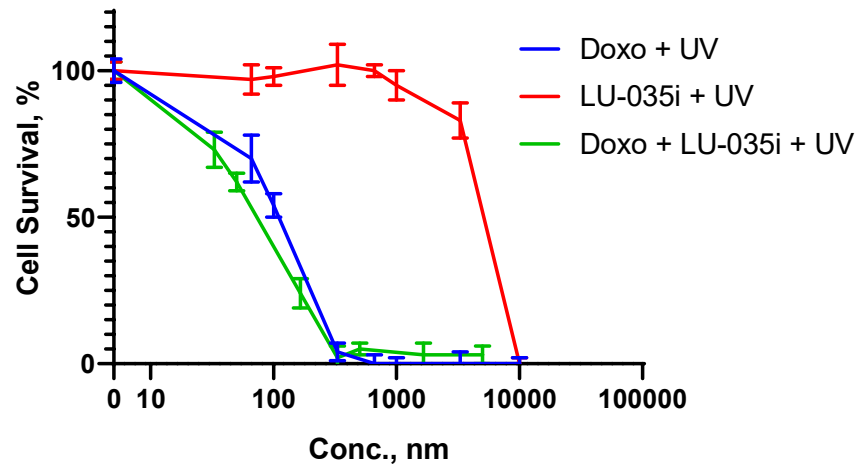

Figure S9. Cell viability on AMO-1 cells by doxorubicin (Doxo), LU-035i and doxorubicin+LU-035i with and without UV irradiation. A) not irradiated. B) Irradiated for $90 \mathrm{sec}$ at $375 \mathrm{~nm}$. Cell survival was measured by Alamar Blue mitochondrial dye conversion assay after $3 \mathrm{~d}$ of incubation with increasing probe concentration in a $5 \% \mathrm{CO}_{2}$ humidified incubator.

A

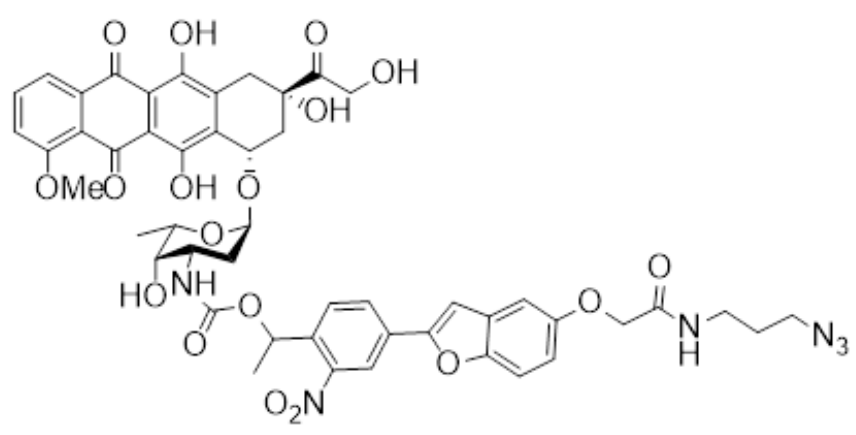

B

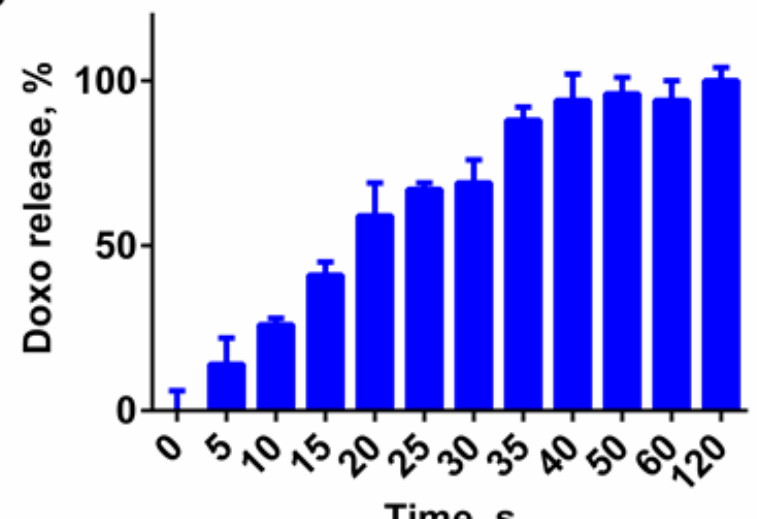

Time, s

Figure S10. Release of doxorubicin from $46(10 \mu \mathrm{M})$ after irradiation at $375 \mathrm{~nm}$ as determined by LC-MS. A) Structure of 46 ; B) Doxo release as measured by LCMS. 


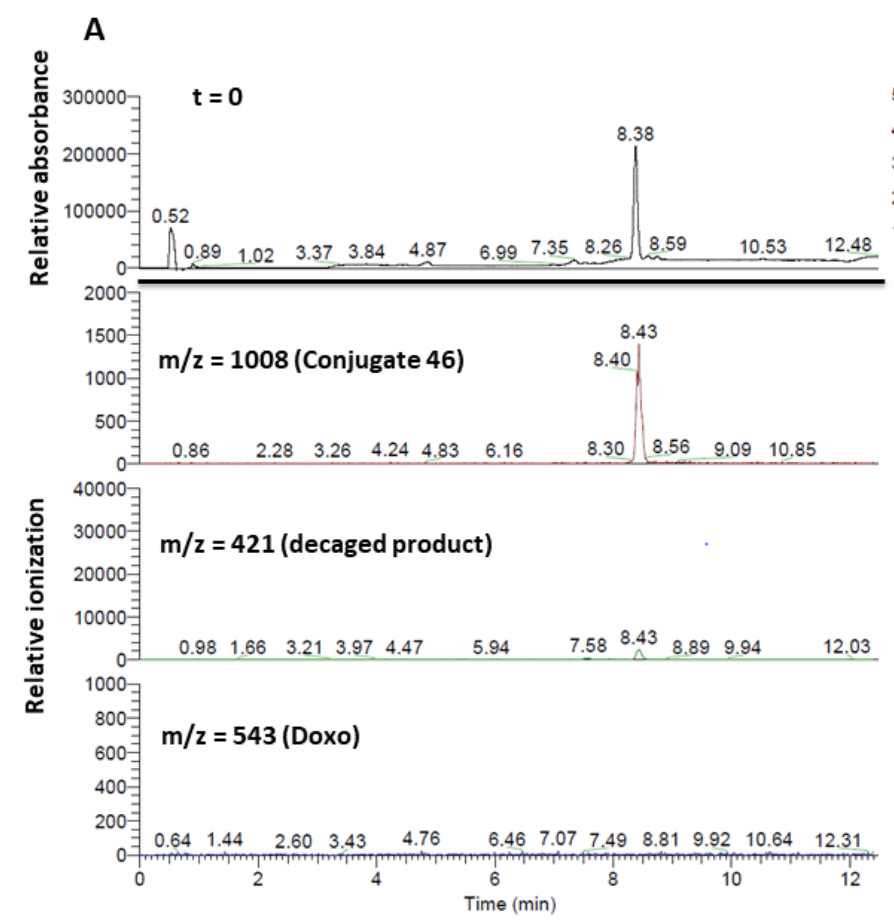

B

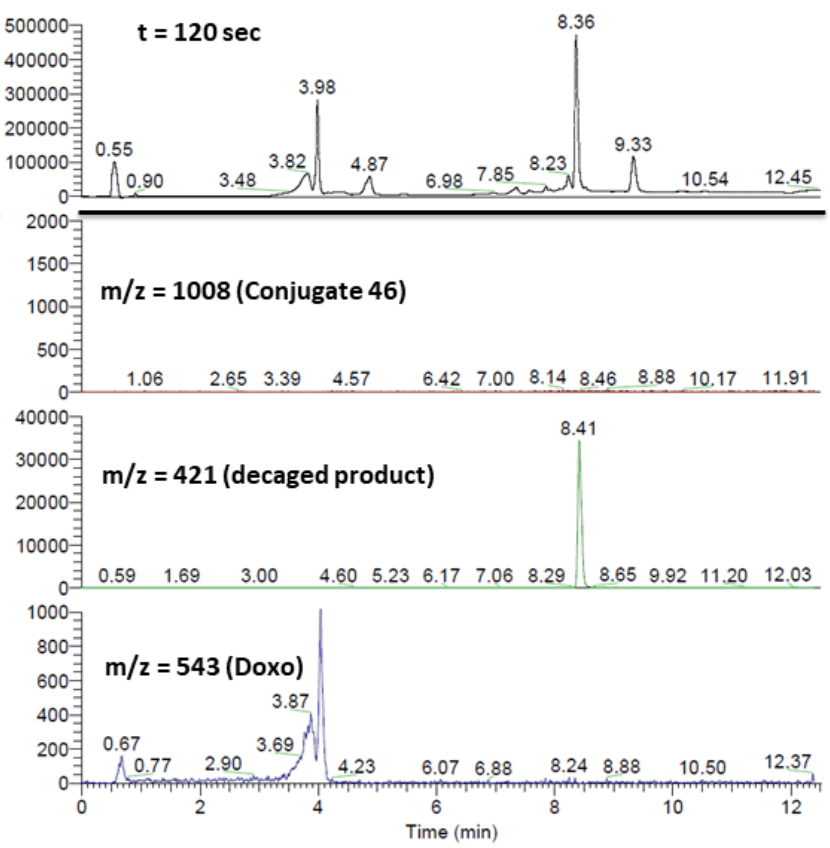

Figure S11. LC-MS spectra of compound 46 after over time irradiation at $375 \mathrm{~nm}$ at defined times in a mixture of 1:1:1 acetonitrile: $t-\mathrm{BuOH}: \mathrm{H}_{2} \mathrm{O}$. A) $\left.\mathrm{t}=0 ; \mathbf{B}\right) \mathrm{t}=120 \mathrm{sec}$.
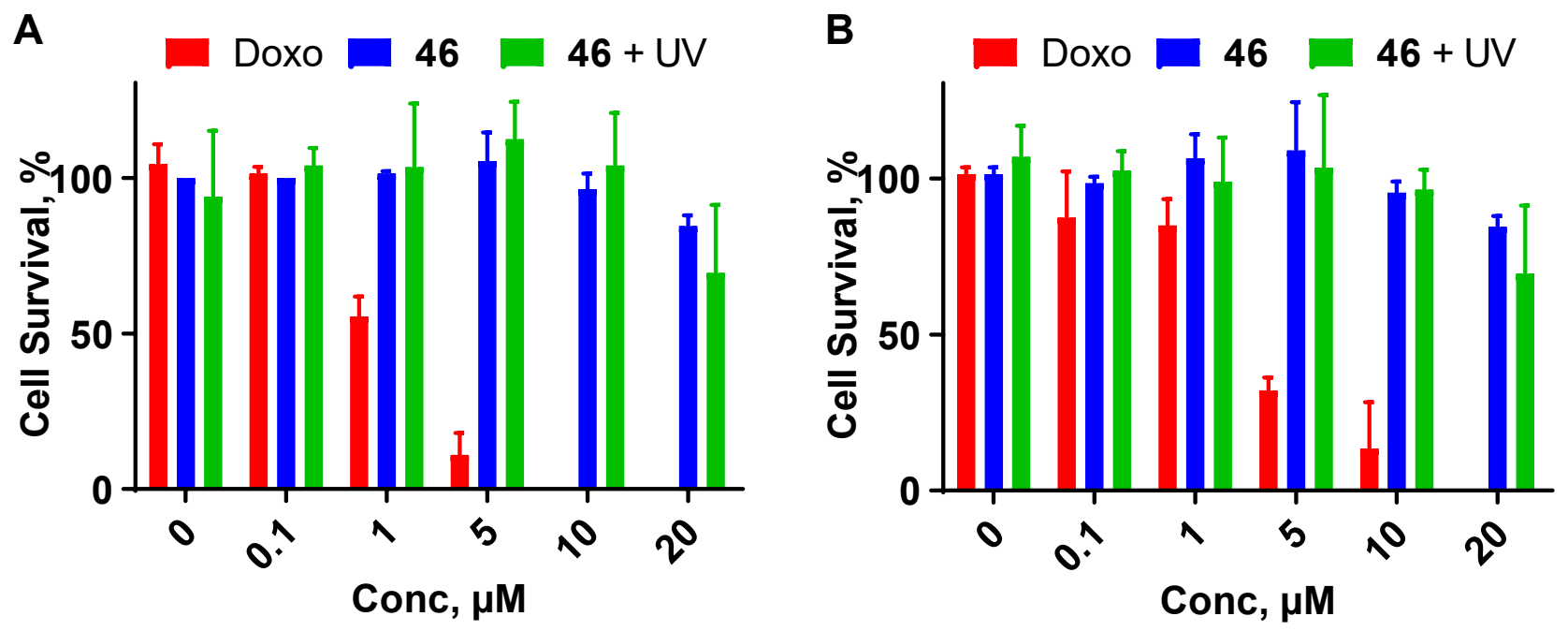

Figure S12. Cell survival of AMO-1 and AMO-CFZ cells when treated with control compound 46. A) AMO-1 cells, B) AMOCFZ resistant cells. Cell survival was measured by Alamar Blue mitochondrial dye conversion assay after 3 days of incubation in a $5 \% \mathrm{CO}_{2}$ humidified incubator. "UV' indicates treatment with $375 \mathrm{~nm}$ light for $90 \mathrm{sec}$. 


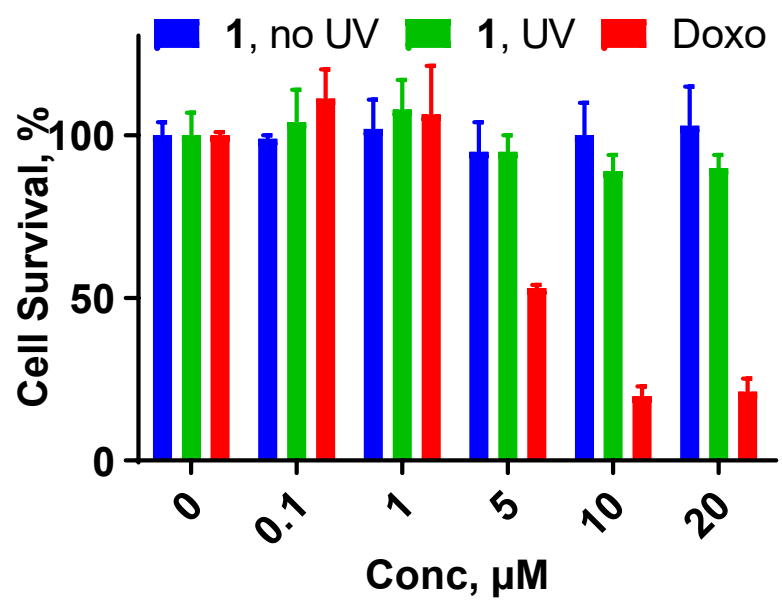

Figure S13. Cell survival of HeLa S3 cells when treated with 1. Cell survival was measured by Alamar Blue mitochondrial dye conversion assay after 3 days of incubation in a $5 \% \mathrm{CO}_{2}$ humidified incubator. "UV" indicates treatment with $375 \mathrm{~nm}$ light for $90 \mathrm{sec}$. 


\section{Biochemical methods}

\section{Competition assay in cell lysate}

Lysates of cells were prepared by sonication in 3 volumes of lysis buffer containing $50 \mathrm{mM}$ Tris pH 7.5, $1 \mathrm{mM} \mathrm{DTT,} 5 \mathrm{mM} \mathrm{MgCl}_{2}, 250$ $\mathrm{mM}$ sucrose, $2 \mathrm{mM}$ ATP, and $0.05 \%$ (w/v) digitonin. Protein concentration was determined by the Bradford assay. Cell lysates (diluted to $5 \mu \mathrm{g}$ of total protein in buffer containing $50 \mathrm{mM}$ Tris $\mathrm{pH} 7.5,2 \mathrm{mM} \mathrm{DTT}, 5 \mathrm{mM} \mathrm{MgCl}, 10 \%$ (v/v) glycerol, $2 \mathrm{mM}$ ATP) were exposed to the inhibitors for $1 \mathrm{~h}$ at $37^{\circ} \mathrm{C}$ prior to incubation with cocktail ABPs for another $1 \mathrm{~h}$, followed by 3 min boiling with a reducing gel-loading buffer and fractionation on 12.5\% SDS PAGE. In-gel detection of residual proteasome activity was performed in the wet gel slabs directly on a ChemiDoc ${ }^{\mathrm{TM}}$ MP system using Cy2 settings to detect BODIPY(FL)-LU-112, Cy3 settings to detect BODIPY(TMR)-NC-005-VS and Cy5 settings to detect Cy5-NC-001. Intensities of bands were measured by fluorescent densitometry and normalized to the intensity of bands in mock-treated extracts. $\mathrm{IC}_{50}$ values were calculated by Graphpad Prism software.

\section{Competitive activity-based protein profiling assays in living AMO-1 cells}

AMO-1 cells were cultured in RPMI-1640 media supplemented with 10\% (v/v) fetal calf serum, GlutaMAX ${ }^{\mathrm{TM}}$, penicillin/streptomycin in a $5 \% \mathrm{CO}_{2}$ humidified incubator. An amount of $5-8 \times 10^{5}$ cells $/ \mathrm{mL}$ cells was exposed to inhibitors for $1 \mathrm{~h}$ at $37^{\circ} \mathrm{C}$. Cells were harvested and washed twice with PBS. Cell pellets were treated with lysis buffer (50 mM Tris pH 7.5, 2 mM DTT, $5 \mathrm{mM} \mathrm{MgCl}_{2}, 10 \%$ (v/v) glycerol, $2 \mathrm{mM}$ ATP, $0.05 \%$ (w/v) digitonin) on ice for $1 \mathrm{~h}$, followed by centrifugation at $14000 \mathrm{rpm}$ for $15 \mathrm{~min}$. Proteasome inhibition in the obtained cell lysates was determined using the method described above. Intensities of bands were measured by fluorescent densitometry and divided by the intensity of bands in mock-treated extracts. Gels were stained by Coomassie Brilliant Blue, which was used to correct for gel loading differences. Average values of three independent experiments were plotted against inhibitor concentrations. $I_{50}$ (inhibitor concentrations giving $50 \%$ inhibition) values were calculated using GraphPad Prism software.

\section{Light induced degradation of conjugates determined by LC-MS}

Conjugate 1 or 2 were dissolved in $100 \mu \mathrm{L}$ 1:1:1 tBuOH:ACN: $\mathrm{H}_{2} \mathrm{O}$ in a glass LC-MS vial in a final concentration of $10 \mu \mathrm{M}$. They were then irradiated for a set time by either a $420 \mathrm{~nm}$ or $375 \mathrm{~nm}$ light source. Next, the solutions were run on an LCMS and the detected conjugate and doxorubicin peaks were integrated individually. Average values of three independent experiments were corrected against an internal standard. The method used was $10 \rightarrow 90 \% 12.5 \mathrm{~min}(0 \rightarrow 2.0 \mathrm{~min}: 20 \% \mathrm{MeCN} ; 2.0 \rightarrow 3.0 \mathrm{~min}: 20 \%$ to $40 \% \mathrm{MeCN}$; $3.0 \rightarrow 6.0 \mathrm{~min}: 40 \% \mathrm{MeCN} ; 6.0 \rightarrow 7.0 \mathrm{~min}: 40 \%$ to $70 \% \mathrm{MeCN} ; 7.0 \rightarrow 11.0 \mathrm{~min}: 70 \% \mathrm{MeCN} ; 11.0 \rightarrow 11.1 \mathrm{~min}: 70 \%$ to $90 \% \mathrm{MeCN}$; $11.1 \rightarrow 12.5 \min : 90 \% \mathrm{MeCN})$.

\section{Cell survival assay}

A $90 \mu \mathrm{L}$ aliquot of AMO- 1 or AMO-CFZ cells $\left(5 \times 10^{4}\right.$ cells per well) was seeded into 96 -well plates, and then treated with $10 \mu \mathrm{L}$ of $0.2 \%$ DMSO or varying concentrations of tested compounds dissolved in RPMI medium for $16 \mathrm{~h}$ in a $5 \% \mathrm{CO}_{2}$ humidified incubator. Next, the cells were spun down (5 min, 200G), washed and resuspended in $100 \mu \mathrm{L}$ RPMI medium, 3 times, followed by irradiation at $375 \mathrm{~nm}$ or $420 \mathrm{~nm}$ for $20-90 \mathrm{sec}$. The cells were then incubated for $3 \mathrm{~d}$ in a $5 \% \mathrm{CO}_{2}$ humidified incubator. Cell viability was measured using the Alamar Blue mitochondrial dye conversion assay. First, $33 \mu \mathrm{L}$ of $50 \mathrm{mM}$ alamar blue solution was pipetted into each well and then incubated for $4 \mathrm{~h}$ at $37{ }^{\circ} \mathrm{C}$ in a humidified, $5 \% \mathrm{CO}_{2}$ atmosphere. The optical density was determined at $490 \mathrm{~nm}$ (background subtraction at $690 \mathrm{~nm}$ ) using a TECAN plate reader. The growth inhibitory ratio was calculated as follows: Growth inhibitory ratio $=$ (Acontrol - Asample)/Acontrol. IC $_{50}$ values were derived from a nonlinear regression model (curvefit) based on a sigmoidal dose response curve (variable slope) and computed using GraphPad Prism software.

\section{Y-H2AX Western blotting}

A $900 \mu \mathrm{L}$ aliquot of AMO-1 cells $\left(5 \times 10^{5}\right.$ cells $\left./ \mathrm{mL}\right)$ was seeded into 12-well plates, and then treated with $100 \mu \mathrm{L}$ of $0.2 \%$ DMSO or varying concentrations of tested compounds dissolved in RPMI medium for $2 \mathrm{~h}$ in a $5 \% \mathrm{CO}_{2}$ humidified incubator. Next, the cells were spun down, washed and redissolved in $1 \mathrm{~mL}$ RPMI medium followed by irradiation at $375 \mathrm{~nm}$ for 60 sec. The cells were then incubated for $2 \mathrm{~h}$ in a $5 \% \mathrm{CO}_{2}$ humidified incubator, followed by transfer to an Eppendorf tube and centrifugation (5 min, $\left.200 \mathrm{G}\right)$. The supernatant was removed carefully and the cells were resuspended in $1 \mathrm{~mL}$ PBS. The cells were lysated by boiling for $5 \mathrm{~min}$ with 100 
$\mu \mathrm{L}$ reducing gel-loading buffer and fractionated on $12.5 \%$ SDS PAGE (15 min $80 \mathrm{~V} \rightarrow 2 \mathrm{~h} 100 \mathrm{~V}$ ). The gel was washed with $\mathrm{H}_{2} \mathrm{O}$ and proteins were transferred to $0.2-\mu \mathrm{m}$ polyvinylidene difluoride membranes with a Trans-Blot TurboTM Transfer system (Bio-Rad). Membranes were washed with TBS $(50 \mathrm{mM}$ Tris, $150 \mathrm{mM} \mathrm{NaCl})$ and blocked with $5 \%$ milk (w/v, Elk magere melkpoeder, FrieslandCampina) in TBST (50 mM Tris, $150 \mathrm{mM} \mathrm{NaCl}, 0.05 \%$ Tween 20) for $1 \mathrm{~h}$ at rt. Membranes were then incubated with the primary antibody Anti-phospho-Histone H2A.X (1:2000) in 5\% milk in TBST for $1 \mathrm{~h}$ at rt, washed with TBST, incubated with the primary antibody Anti-actin mAb (1:5000) in 5\% milk in TBST for $1 \mathrm{~h}$ at rt followed by washing with TBST. Matching secondary antibody HRPcoupled-goatanti-rabbit (1:5000, Santa Cruz, sc2030) in 5\% milk in TBST (1 h, rt) was added and incubated for $1 \mathrm{~h}$ at rt followed by washing with TBST and $\mathrm{H}_{2} \mathrm{O}$. Imaging solution ( $10 \mathrm{~mL}$ Luminol, $100 \mu \mathrm{L}$ ECL enhancer, $3 \mu \mathrm{L} \mathrm{H}_{2} \mathrm{O}_{2}$ ) was added to develop membranes and chemiluminescence was detected on the ChemiDoc (Bio-Rad) using standard chemiluminescence settings. The $\mathrm{Y}-\mathrm{H} 2 \mathrm{AX}$ signal was normalized to the actin signal and quantified with Image Lab 6.0. 


\section{Synthetic procedures}

\section{General experimental procedures}

All reagents were of commercial grade and used as received unless stated otherwise. Solvents used in synthesis were dried and stored over $4 \AA$ molecular sieves, except $\mathrm{MeOH}$ and $\mathrm{ACN}$ which were stored over $3 \AA$ molecular sieves. Triethylamine $\left(\mathrm{Et}_{3} \mathrm{~N}\right)$ and $\mathrm{Di}-$ isopropylethylamine (DiPEA) were stored over $\mathrm{KOH}$ pellets.

Column chromatography was performed on silica gel $60 \AA$ (40-63 $\mu \mathrm{m}$, Macherey-Nagel). TLC analysis was performed on Macherey-Nagel aluminium sheets (silica gel $60 \mathrm{~F}_{254}$ ).

TLC was used to visualize compounds by UV at wavelength $254 \mathrm{~nm}$ and by spraying with either cerium molybdate spray (25g/L $(\mathrm{NH} 4)_{6} \mathrm{Mo}_{7} \mathrm{O}_{24}, 10 \mathrm{~g} / \mathrm{L}(\mathrm{NH} 4)_{4} \mathrm{Ce}\left(\mathrm{SO}_{4}\right)_{4} \cdot \mathrm{H}_{2} \mathrm{O}$ in $10 \% \mathrm{H}_{2} \mathrm{SO}_{4}$ water solution) or $\mathrm{KMnO}_{4}$ spray $\left(20 \mathrm{~g} / \mathrm{L} \mathrm{KMnO}_{4}\right.$ and $10 \mathrm{~g} / \mathrm{L} \mathrm{K}_{2} \mathrm{CO}_{3}$ in water $)$ followed by charring at c.a. $250{ }^{\circ} \mathrm{C}$.

LC-MS analysis was performed on a Finnigan Surveyor HPLC system with a Nucleodur C18 Gravity 3 um 50 x $4.60 \mathrm{~mm}$ column (detection at 200-600 nm) coupled to a Finnigan LCQ Advantage Max mass spectrometer with ESI or coupled to a Thermo LCQ Fleet Ion mass spectrometer with ESI. The Method used was $10 \rightarrow 90 \% 13.5 \mathrm{~min}(0 \rightarrow 0.5 \mathrm{~min}: 10 \% \mathrm{MeCN} ; 0.5 \rightarrow 8.5 \mathrm{~min}: 10 \%$ to $90 \%$ $\mathrm{MeCN} ; 8.5 \rightarrow 11 \mathrm{~min}: 90 \% \mathrm{MeCN} ; 11 \rightarrow 13.5 \mathrm{~min}: 10 \% \mathrm{MeCN})$.

High-resolution mass spectrometry (HRMS) was performed on a Thermo Scientific Q Exactive HF Orbitrap mass spectrometer equipped with an electrospray ion source in positive-ion mode (source voltage $3.5 \mathrm{kV}$, sheath gas flow 10, capillary temperature $275^{\circ} \mathrm{C}$ ) with resolution $\mathrm{R}=240.000$ at $\mathrm{m} / \mathrm{z} 400$ (mass range of 150-6000) correlated to an external calibration, or on a Waters Synapt G2-Si (TOF) equipped with an electrospray ion source in positive mode (source voltage $3.5 \mathrm{kV}$ ) and LeuEnk $(\mathrm{m} / \mathrm{z}=556.2771)$. as internal lock mass.

${ }^{1} \mathbf{H}$ and ${ }^{13} \mathbf{C}$ NMR spectra were recorded on a Bruker AV-400 NMR, a Bruker DMX-400 NMR instrument (400 and $101 \mathrm{MHz}$ respectively), a Bruker AV-500 NMR instrument (500 and $126 \mathrm{MHz}$ respectively), and Bruker AV-600 NMR instrument (600 and 151 $\mathrm{MHz}$ respectively). Chemical shifts $(\delta)$ are given in ppm relative to tetramethylsilane as internal standard or the residual signal of the deuterated solvent. Coupling constants $(J)$ are given in Hz. All given ${ }^{13} \mathrm{C}-\mathrm{APT}$ spectra are proton decoupled. Assignment of NMR spectra was based on ${ }^{1} \mathrm{H}-\mathrm{COSY}$ and ${ }^{1} \mathrm{H}-{ }^{13} \mathrm{C}-\mathrm{HSQC}$.

HPLC purification was performed on a Gilson HPLC system coupled to a Magerey-Nagel Nucleodur C18 Gravity $5 \mu \mathrm{m} 250 \times 10 \mathrm{~mm}$ column, or on an Agilent $1200 \mathrm{HPLC} / 6130 \mathrm{MS}$ system coupled to a Magerey-Nagel Nucleodur C18 Gravity $5 \mu \mathrm{m} 250 \times 10 \mathrm{~mm}$ column or on a Waters autopurifier HPCL/MS system coupled to a Phenomenex Gemini 5 $\mu \mathrm{m} 150 \times 21.2 \mathrm{~mm}$ column. 
A) Synthesis of bis-functionalized NPBF-based photoprotecting group

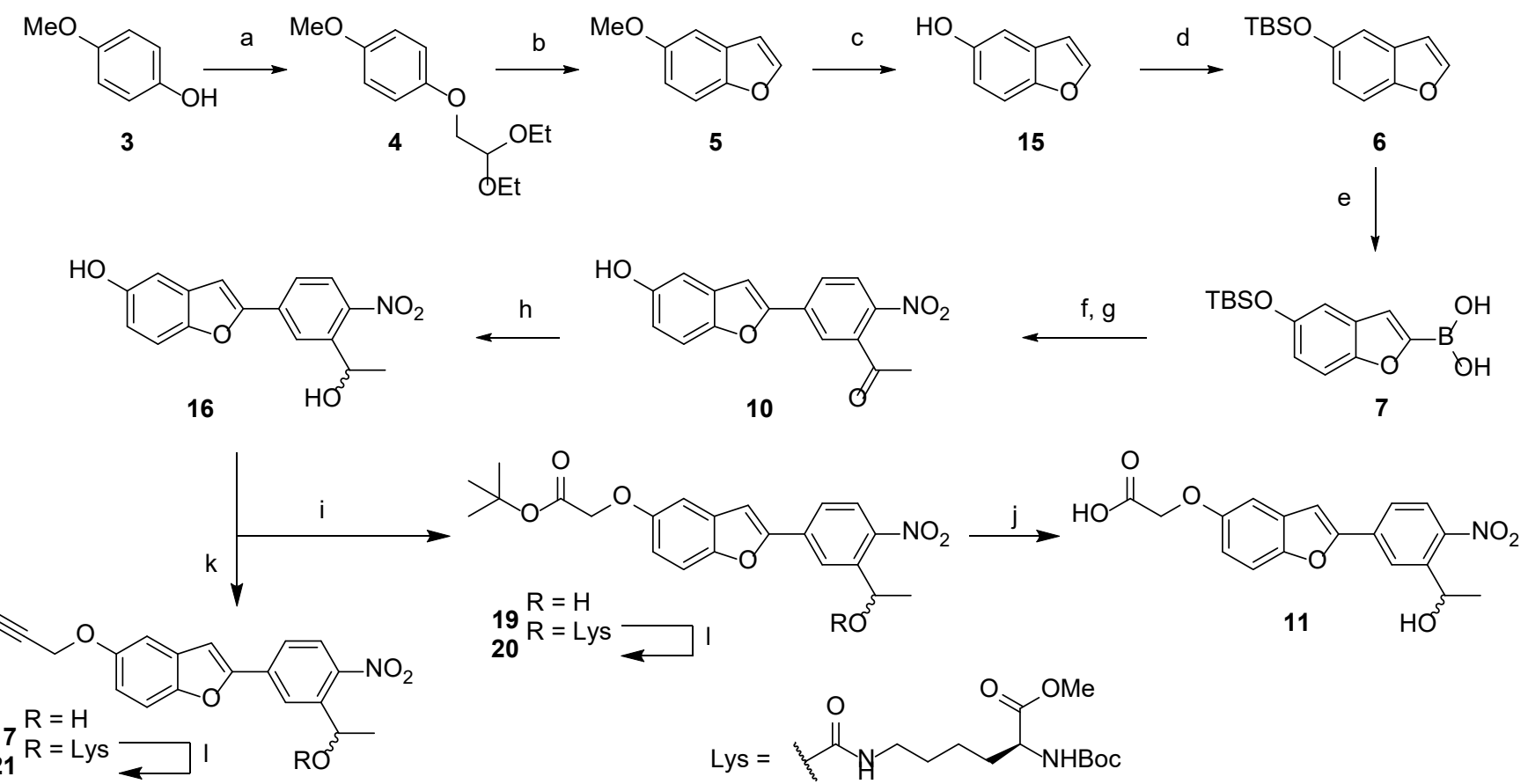

Scheme S1. Synthesis of bis-functionalized NPBF-based photoprotecting group 12. Reagents and conditions: a) bromoacetaldehyde diethyl acetal, $\mathrm{KOH}, \mathrm{DMAC}, 90^{\circ} \mathrm{C}, 3 \mathrm{~h}, 90 \%$; b) PPA, toluene, $111^{\circ} \mathrm{C}, 16 \mathrm{~h}, 33 \%$; c) $1 \mathrm{M} \mathrm{BBr}_{3}$ in $\mathrm{DCM}$, DCM, $-78^{\circ} \mathrm{C}(1 \mathrm{~h}) \rightarrow$ r.t. $(1 \mathrm{~h})$, $89 \%$; d) TBS-Cl, imidazole, DMF, $1 \mathrm{~h}$, r.t., $70 \%$; e) (i) $1.6 \mathrm{M} \mathrm{n}-\mathrm{BuLi}$ in hexanes, THF, $-78^{\circ} \mathrm{C}, 1 \mathrm{~h}$, (ii) triisopropyl borate, $-78^{\circ} \mathrm{C}(0.5 \mathrm{~h}) \rightarrow$ r.t. (0.5h); f) 8, $\mathrm{Pd}\left(\mathrm{PPh}_{3}\right)_{4}, \mathrm{~K}_{2} \mathrm{CO}_{3}, \mathrm{THF} / \mathrm{H}_{2} \mathrm{O}, 75^{\circ} \mathrm{C}, 18 \mathrm{~h}, 75 \%$; g) HF.pyridine, THF, r.t., $2 \mathrm{~h}, 93 \%$; h) (i) $\mathrm{NaBH}, \mathrm{MeOH}^{\circ} \mathrm{C}, 1 \mathrm{~h}, \mathrm{qt}$; i) tert-butyl bromoacetate, $\mathrm{K}_{2} \mathrm{CO}_{3}$, DMF, $70^{\circ} \mathrm{C}$, 3h, $72 \%$; j) TFA, DCM, r.t., 3h, qt.; k) propargyl bromide, $\mathrm{K}_{2} \mathrm{CO}_{3}$, DMF, r.t., $1 \mathrm{~h}$, $98 \%$; I) (i) $N, N^{\prime}$-disuccinimidyl carbonate, $\mathrm{Et}_{3} \mathrm{~N}$, acetonitrile or DMF, r.t., $16 \mathrm{~h}$, (ii) Boc-Lys-OMe-HOAc, r.t., 15 min, protected from UV, $55-66 \%$.

1-(2,2-diethoxyethoxy)-4-methoxybenzene (4). A procedure from literature ${ }^{[1]}$ was modified as follows: 4-methoxyphenol (300 mmol,<smiles>CCOC(COc1ccc(OC)cc1)OCC</smiles>
$37.2 \mathrm{~g})$ was dissolved in NMP $(300 \mathrm{~mL}, 1 \mathrm{M})$ followed by addition of potassium hydroxide $(600 \mathrm{mmol}, 33.6 \mathrm{~g})$ at r.t. Bromoacetaldehyde diethyl acetal $(7.5 \mathrm{mmol}, 1.13 \mathrm{~mL})$ was added slowly and the reaction was stirred at $70^{\circ} \mathrm{C}$ for 15 h. TLC analysis indicated complete conversion of the starting material (10\% $\mathrm{Et}_{2} \mathrm{O}$ in $\left.\mathrm{Pnt}, \mathrm{R}_{\mathrm{f}}=0.7\right)$. The reaction mixture was poured in $\mathrm{H}_{2} \mathrm{O}$ and extracted with $\mathrm{Et}_{2} \mathrm{O}(3 \mathrm{x})$. The combined organic layers were washed with brine (1x), dried over $\mathrm{MgSO}_{4}$ and concentrated in vacuo. Purification by silica gel column chromatography $\left(5 \% \mathrm{Et}_{2} \mathrm{O} \rightarrow 10 \%\right.$ $\mathrm{Et}_{2} \mathrm{O}$ in Pnt) yielded compound 4 (270 mmol, $\left.64.9 \mathrm{~g}, 90 \%\right) .{ }^{1} \mathrm{H}$ NMR $(400 \mathrm{MHz}$, Chloroform- $d) \delta=6.90-6.76(\mathrm{~m}, 4 \mathrm{H}), 4.80(\mathrm{t}, \mathrm{J}=5.2$, $1 \mathrm{H}), 3.95(\mathrm{~d}, \mathrm{~J}=5.2,2 \mathrm{H}), 3.80-3.68(\mathrm{~m}, 2 \mathrm{H}), 3.72(\mathrm{~s}, 3 \mathrm{H}), 3.61(\mathrm{dq}, J=9.4,7.0,2 \mathrm{H}), 1.23(\mathrm{t}, J=7.1,6 \mathrm{H}) .{ }^{13} \mathrm{C} \mathrm{NMR}(101 \mathrm{MHz}, \mathrm{CDCl} 3) \delta$ $=153.94,152.71,115.53,114.46,100.49,69.13,62.36,55.48,15.26$.<smiles>COc1ccc2occc2c1</smiles>

5-methoxybenzofuran (5). A procedure from literature ${ }^{[2]}$ was modified as follows: Polyphosphoric acid (60 g, $\mathrm{H}_{3} \mathrm{PO}_{4}$ basis, $115 \%$ ) was dissolved in toluene $(600 \mathrm{~mL})$ and the mixture was heated to $110^{\circ} \mathrm{C}$ under vigorous stirring. Compound 4 (255 mmol, $61.3 \mathrm{~g}$ ) was dissolved in toluene (160 mL, $1.6 \mathrm{M})$ and was dropwise added to the solution over the course of 1 hour. After stirring for 1 hour at reflux temperature TLC indicated complete conversion of the starting material $\left(5 \% \mathrm{Et}_{2} \mathrm{O}\right.$ in Pnt, $\left.\mathrm{R}_{\mathrm{f}}=0.8\right)$. The mixture was cooled to r.t., decanted in $1 \mathrm{M} \mathrm{NaOH}(\mathrm{aq})$ and extracted with toluene. The combined organic layers were washed with brine (1x), dried over $\mathrm{MgSO}_{4}$ and concentrated in vacuo. Purification by silica gel column chromatography (Pnt $\rightarrow 2 \% \mathrm{Et}_{2} \mathrm{O}$ in Pnt) yielded compound $5(83.1 \mathrm{mmol}, 12.3 \mathrm{~g}, 33 \%) .{ }^{1} \mathrm{H} \mathrm{NMR}(400 \mathrm{MHz}, \mathrm{Chloroform}-d) \delta=7.59$ (dd, J=2.2, 0.5, 1H), 7.39 (ddd, J=8.9, 1.0, 0.5, 1H), 7.05 (d, J=2.6, 1H), 6.90 (ddd, J=8.9, 2.6, 0.5, 1H), 6.70 (dd, J=2.2, 0.9, 1H) $3.84(\mathrm{~s}, 3 \mathrm{H}) .{ }^{13} \mathrm{C}$ NMR $\left(101 \mathrm{MHz}, \mathrm{CDCl}_{3}\right) \delta=145.86,128.08,113.20,111.93,106.82,103.61,56.03$. 
Benzofuran-5-ol (15). A procedure from literature ${ }^{[3]}$ was modified as follows: Compound 5 (5.7 mmol, $\left.849 \mathrm{mg}\right)$ was dissolved in $\mathrm{HO}$ anhydrous DCM $(8.1 \mathrm{~mL}, 0.7 \mathrm{M})$ under a nitrogen atmosphere. The mixture was cooled to $-78^{\circ} \mathrm{C}$ after which a $1 \mathrm{M}$ solution of $\mathrm{BBr}_{3}$ in $\mathrm{DCM}(6.8 \mathrm{mmol}, 6.8 \mathrm{~mL})$ was slowly added. The mixture was stirred at $-78^{\circ} \mathrm{C}$ for 1 hour and then heated to r.t. and stirred for an additional hour. TLC analysis indicated complete conversion of the starting material $\left(20 \%\right.$ EtOAc in Pnt, $\left.\mathrm{R}_{\mathrm{f}}=0.7\right)$. The reaction was quenched with saturated solution of $\mathrm{NaHCO}_{3}$ (aq.), poured in $\mathrm{H}_{2} \mathrm{O}$ and extracted with EtOAc (3x). The combined organic layers were washed with brine (1x), dried over $\mathrm{MgSO}_{4}$ and concentrated in vacuo. Purification with silica gel column chromatography (5\% EtOAc $\rightarrow 10 \%$ EtOAc in Pnt) yielded compound 15 (5.11 mmol, $0.685 \mathrm{~g}$, 89\%). ${ }^{1} \mathrm{H}$ NMR (400 MHz, Chloroform- $d$ ) $\delta=7.59$ (dd, $\left.J=2.2,0.5,1 \mathrm{H}\right), 7.35$ (ddd, $J=8.8,1.0,0.5,1 \mathrm{H}$ ), 7.01 (dd, $J=2.6,0.6,1 \mathrm{H}$ ), 6.81 (ddd, $J=8.8,2.6,0.5,1 \mathrm{H}), 6.67(\mathrm{dd}, J=2.2,0.9,1 \mathrm{H}), 4.89(\mathrm{~s}, 1 \mathrm{H}) .{ }^{13} \mathrm{C} \mathrm{NMR}\left(101 \mathrm{MHz}, \mathrm{CDCl}_{3}\right) \delta=146.12,113.05,111.92,106.56$, 106.21 .

(benzofuran-5-yloxy)(tert-butyl)dimethylsilane (6). Compound 15 (3.73 mmol, $0.501 \mathrm{~g}$ ) was dissolved in anhydrous DMF (3.8 $\mathrm{mL}$, TBSO<smiles>Ic1ccc2occc2c1</smiles>
$1 \mathrm{M})$ under a nitrogen atmosphere. A $50 \mathrm{wt} \%$ solution of tert-butyldimethylsilyl chloride in toluene $(11.3 \mathrm{mmol}$, $3.9 \mathrm{~mL}, 2.9 \mathrm{M}$ ) was added followed by the addition of imidazole $(18.7 \mathrm{mmol}, 1.27 \mathrm{~g})$. The mixture was stirred for 1 hour at r.t. TLC analysis indicated complete conversion of the starting material $\left(1 \% \mathrm{Et}_{2} \mathrm{O}\right.$ in Pnt, $\left.\mathrm{R}_{\mathrm{f}}=0.7\right)$. The mixture was then poured in $\mathrm{H}_{2} \mathrm{O}$ and extracted with $\mathrm{Et}_{2} \mathrm{O}(3 \mathrm{x})$. The combined organic layers were washed with brine (1x), dried over $\mathrm{MgSO}_{4}$ and concentrate in vacuo. Purification with silica gel column chromatography (Pnt $\rightarrow 1 \% \mathrm{Et}_{2} \mathrm{O}$ in Pnt) yielded compound 6 (2.62 mmol, $0.65 \mathrm{~g}, 70.2 \%)$. ${ }^{1} \mathrm{H}$ NMR $(400 \mathrm{MHz}$, Chloroform- $d$ ) $\delta=7.60$ (d, J=2.1, 1H), 7.38 (dd, J=8.8, 0.9, 1H), 7.06 (d, J=2.5, 1H), $6.85(\mathrm{dd}, J=8.8,2.4,1 \mathrm{H}), 6.69(\mathrm{dd}, \mathrm{J}=2.2,0.9,1 \mathrm{H}), 1.05(\mathrm{~d}, \mathrm{~J}=0.9,10 \mathrm{H}), 0.24(\mathrm{~d}, \mathrm{~J}=0.8,6 \mathrm{H}) .{ }^{13} \mathrm{C} \mathrm{NMR}\left(101 \mathrm{MHz}, \mathrm{CDCl}_{3}\right) \delta=151.50$, $150.46,145.75,128.22,117.63,111.61,111.10,106.69,30.45,25.88,18.35,-4.33$.

(5-((tert-butyldimethylsilyl)oxy)benzofuran-2-yl)boronic acid (7). Compound 6 (3.65 mmol, $0.906 \mathrm{~g})$ was dissolved in anhydrous I BSU OH THF $(20 \mathrm{~mL}, 0.2 \mathrm{M})$ under a nitrogen atmosphere and cooled to $-78^{\circ} \mathrm{C}$. A $1.6 \mathrm{M}$ solution of $\mathrm{n}$-butyllithium in hexanes $(8.0 \mathrm{mmol}, 5.02 \mathrm{~mL})$ was added dropwise and the mixture was stirred for 1 hour. Triisopropyl borate $(4.4 \mathrm{mmol}, 1.0 \mathrm{~mL})$ was added dropwise and the mixture was stirred for another $30 \mathrm{~min}$. The mixture was then heated to r.t. and stirred for an additional $30 \mathrm{~min}$. The reaction mixture was quenched with a $2 \mathrm{M}$ solution of $\mathrm{HCl}$ (aq.) $(4 \mathrm{~mL}, 8 \mathrm{mmol})$, poured in $\mathrm{H}_{2} \mathrm{O}$ and extracted with EtOAc $(3 \mathrm{x})$. The combined organic layers were washed with $\mathrm{H}_{2} \mathrm{O}(1 \mathrm{x})$ and brine (1x), dried over $\mathrm{MgSO}_{4}$ and concentrated in vacuo. The crude product 7 was used as is in the following reaction.

4'-bromo-2'-nitroacetophenone (8). $\mathrm{KNO}_{3}(24.0 \mathrm{mmol}, 2.42 \mathrm{~g})$ was loaded into a flask and cooled down to $-20^{\circ} \mathrm{C} . \mathrm{H}_{2} \mathrm{SO}_{4}(21.75 \mathrm{~mL}$,<smiles>CC(=O)c1cc(Br)ccc1[N+](=O)[O-]</smiles>
$98 \%$ ) was added and the mixture was stirred for $30 \mathrm{~min}$. 3'-bromoacetophenone (20 mmol, $3.98 \mathrm{~g}, 2.64 \mathrm{~mL})$ was slowly added. The reaction mixture was heated up to $-10^{\circ} \mathrm{C}$ and stirred for another $2 \mathrm{~h}$. The reaction mixture was poured into crushed ice and extracted with DCM (3x). The combined organic layers were washed with brine (1x), dried over $\mathrm{MgSO}_{4}$ and concentrated in vacuo. The crude was dissolved in a minimal amount of $\mathrm{Et}_{2} \mathrm{O}$ after which Pnt was added until a precipitation was visible. The suspension was gently warmed until the precipitate dissolved again. The product was allowed to crystallize out of solution until no more formation of crystals was observed. The crystals were collected and washed with cold Pnt yielding compound 8 (9.8 mmol, $2.4 \mathrm{~g}, 49 \%)$. ${ }^{1} \mathrm{H}$ NMR $(400 \mathrm{MHz}$, Chloroform- $d$ ) $\delta=8.00(\mathrm{~d}, \mathrm{~J}=8.7,1 \mathrm{H}), 7.74$ (dd, J=8.7, 2.1, 1H), 7.55 (d, J=2.1, 1H), $2.56(\mathrm{~s}, 3 \mathrm{H}) .{ }^{13} \mathrm{C}$ NMR $\left(101 \mathrm{MHz}, \mathrm{CDCl}_{3}\right) \delta=133.75,130.47,126.05,30.37$.

Silyl photocage 9. Compound 7 (4.62 mmol, $1.35 \mathrm{~g})$ and compound 8 (3.65 mmol, $0.89 \mathrm{~g})$ were dissolved in a 1:1 mixture of THF<smiles>CC(=O)c1cc(-c2cc3cc(O[AsH2])ccc3o2)ccc1[N+](=O)[O-]</smiles>
and $\mathrm{H}_{2} \mathrm{O}(42 \mathrm{~mL})$ under a nitrogen atmosphere. The flask was wrapped in aluminum foil and $\mathrm{K}_{2} \mathrm{CO}_{3}(5.48 \mathrm{mmol}, 0.757 \mathrm{~g})$ and $\mathrm{Pd}\left(\mathrm{Ph}_{3}\right)_{4}(0.23 \mathrm{mmol}, 0.266 \mathrm{~g})$ were added. The mixture was heated to $66^{\circ} \mathrm{C}$ and refluxed for $18 \mathrm{~h}$. TLC analysis indicated complete conversion of the starting material $\left(10 \% \mathrm{Et}_{2} \mathrm{O}\right.$ in $\left.\mathrm{Pnt}, \mathrm{R}_{\mathrm{f}}=0.3\right)$. The reaction mixture was quenched using a saturated solution of $\mathrm{NH}_{4} \mathrm{Cl}$ (aq.), poured in $\mathrm{H}_{2} \mathrm{O}$ and extracted with EtOAc (3x). The combined organic layers were washed with brine (1x), dried over $\mathrm{MgSO}_{4}$ and concentrated in vacuo. The crude mixture consists of partially desilylated product, so the crude mixture can be used as is in the following reaction. Purification with silica gel column chromatography ( $5 \% \mathrm{Et}_{2} \mathrm{O} \rightarrow 30 \% \mathrm{Et}_{2} \mathrm{O}$ in $\left.\mathrm{Pnt}\right)$ yielded compound 9 (2.23 mmol, $0.919 \mathrm{~g}, 61 \%)$. Increasing the polarity of the eluent $\left(30 \% \mathrm{Et}_{2} \mathrm{O}\right.$ in Pnt $\rightarrow 30 \%$ EtOAc in Pnt) yielded 
prematurely desilylated compound $10(0.51 \mathrm{mmol}, 0.15 \mathrm{~g}, 14 \%) .{ }^{1} \mathrm{H}$ NMR $(400 \mathrm{MHz}$, Chloroform- $d) \delta=8.09(\mathrm{~d}, J=8.6,1 \mathrm{H}), 7.87(\mathrm{dd}$, $J=8.6,1.9,1 \mathrm{H}), 7.76(\mathrm{~d}, J=1.8,1 \mathrm{H}), 7.36$ (dt, J=8.9, 0.8, 1H), 7.13 (d, J=0.9, 1H), 7.05 (d, J=2.4, 1H), 6.89 (dd, J=8.8, 2.5, $1 \mathrm{H}), 2.61$ (s, 3H), 1.04 (d, J=0.7, 13H), 0.25 (d, J=0.7, 7H). $\left.{ }^{13} \mathrm{C} \mathrm{NMR} \mathrm{(101} \mathrm{MHz,} \mathrm{CDCl}\right) \delta=199.76,152.82,152.03,150.87,144.03,139.06$, $136.13,129.17,125.65,125.14,122.72,119.69,111.72,111.24,105.94,30.24,25.69,18.18,-4.48$.

Hydroxyl photocage 10. Compound $9(0.66 \mathrm{mmol}, 0.27 \mathrm{~g})$ was dissolved in anhydrous THF $(7 \mathrm{~mL})$ under a nitrogen atmosphere. A HO<smiles>CC(=O)c1cc(-c2cc3cc(C)ccc3o2)ccc1[N+](=O)[O-]</smiles>
solution of $70 \% \mathrm{HF}$ in Pyridine $(0.7 \mathrm{~mL}, 10$ vol\%) was added and the reaction was stirred at r.t. for $2 \mathrm{~h}$. TLC analysis indicated complete conversion of the starting material (30\% EtOAc in Pnt, $\mathrm{R}_{\mathrm{f}}=0.2$ ). The reaction was quenched with a saturated solution of $\mathrm{NaHCO}_{3}$ (aq.) until no $\mathrm{CO}_{2}$ release was observed. The mixture was poured into $\mathrm{H}_{2} \mathrm{O}$ and extracted with EtOAc (3x). The combined organic layers were washed with brine (1x), dried over $\mathrm{MgSO}_{4}$ and concentrated in vacuo. Purification with silica gel column chromatography (15\% EtOAc $\rightarrow$ 30\% EtOAc in Pnt) yielded compound 10 (0.62 mmol, $0.18 \mathrm{~g}, 93 \%) .{ }^{1} \mathrm{H} \mathrm{NMR} \mathrm{(400} \mathrm{MHz,}$ DMSO- $\left.d_{6}\right) \delta=9.40(\mathrm{~s}, 1 \mathrm{H}), 8.22(\mathrm{~d}, J=8.4,1 \mathrm{H}), 8.17-8.09(\mathrm{~m}, 2 \mathrm{H}), 7.67(\mathrm{~s}, 1 \mathrm{H}), 7.47(\mathrm{~d}, \mathrm{~J}=8.8,1 \mathrm{H}), 7.01(\mathrm{~d}, \mathrm{~J}=2.5,1 \mathrm{H}), 6.86(\mathrm{dd}$, $J=8.9,2.5,1 \mathrm{H}), 2.63(\mathrm{~s}, 3 \mathrm{H}) .{ }^{13} \mathrm{C}$ NMR $(101 \mathrm{MHz}, \mathrm{DMSO}) \delta=199.78,153.96,152.61,149.26,144.26,138.03,135.30,129.18$, $126.15,125.61,123.21,115.36,111.85,106.77,105.83,30.06$.

Photocage 16. Compound $10(0.36 \mathrm{mmol}, 0.106 \mathrm{~g})$ was dissolved in methanol $(3.6 \mathrm{~mL}, 0.1 \mathrm{M})$ and the mixture was cooled down to $0^{\circ} \mathrm{C}$. $\mathrm{NaBH}_{4}(0.54 \mathrm{mmol}, 0.020 \mathrm{~g})$ was added in portions. After addition the mixture was heated to r.t. and stirred for 1 hour. TLC<smiles>C[C@H](O)c1cc(-c2cc3cc(O)ccc3o2)ccc1[N+](=O)[O-]</smiles>
analysis indicated full conversion of the starting material (30\% EtOAc in Pnt, $\left.R_{f}=0.2\right)$. The mixture was concentrated in vacuo after which it was dissolved in $\mathrm{H}_{2} \mathrm{O}$ and extracted with EtOAc $(3 \mathrm{x})$. The combined organic layers were washed with brine $(1 \mathrm{x})$ and dried over $\mathrm{MgSO}_{4}$. Concentration in vacuo yielded compound $16(0.36 \mathrm{mmol}, 108 \mathrm{mg}, 100 \%)$. ${ }^{1} \mathrm{H}$ NMR $\left(400 \mathrm{MHz}\right.$, DMSO- $\left.d_{6}\right) \delta=9.36$ (s, 1H), 8.29 (d, J=1.9, 1H), $8.04(\mathrm{~d}, J=8.5,1 \mathrm{H}), 7.96(\mathrm{dd}, J=8.5,1.9,1 \mathrm{H}), 7.57(\mathrm{~d}, J=0.9,1 \mathrm{H}), 7.49$ (d, J=8.9, 1H), $7.00(\mathrm{~d}, J=2.4,1 \mathrm{H}), 6.83$ (dd, J=8.8, 2.5, 1H), $5.66(\mathrm{~d}, J=4.3,1 \mathrm{H}), 5.30-5.20(\mathrm{~m}, 1 \mathrm{H}), 1.43(\mathrm{~d}, \mathrm{~J}=6.3,3 \mathrm{H}) .{ }^{13} \mathrm{C} \mathrm{NMR}$ $(101 \mathrm{MHz}, \mathrm{DMSO}) \delta=153.85,146.24,143.61,143.61,134.44,129.31,125.17,123.70,123.04,114.82,111.77,105.74,105.50$, $64.01,25.09$.

Alkyne photocage 17. Compound $16(0.50 \mathrm{mmol}, 0.15 \mathrm{~g})$ was dissolved in DMF $(0.2 \mathrm{M}, 2.5 \mathrm{~mL}) . \mathrm{K}_{2} \mathrm{CO}_{3}(1.92 \mathrm{mmol}, 0.265 \mathrm{~g})$ was<smiles>C#CCOc1ccc2oc(-c3ccc([N+](=O)[O-])c([C@H](C)O)c3)cc2c1</smiles>
added and the reaction mixture was stirred for 1 hour at r.t.. Propargyl bromide $(1.2 \mathrm{mmol}$, $108 \mu \mathrm{L}$ ) was added to the reaction and the mixture was stirred overnight. TLC analysis indicated full conversion the starting material (30\% EtOAc in Pnt, $\left.\mathrm{R}_{\mathrm{f}}=0.7\right)$. The reaction was quenched with a saturated solution of $\mathrm{NH}_{4} \mathrm{Cl}$ (aq.) and extracted with EtOAc (3x). The combined organic layers were washed with brine $(1 \mathrm{x})$ and concentrated in vacuo. Purification with silica gel column chromatography (10\% EtOAc $\rightarrow$ 15\% EtOAc in Pnt) yielded compound 17 (0.49 mmol, $0.164 \mathrm{~g}$, 98\%). ${ }^{1} \mathrm{H}$ NMR $\left(400 \mathrm{MHz}\right.$, Acetone- $\left.d_{6}\right) \delta=8.40(\mathrm{~d}, \mathrm{~J}=2.0,1 \mathrm{H}), 7.97(\mathrm{~d}, \mathrm{~J}=8.6,1 \mathrm{H}), 7.89(\mathrm{dd}, J=8.5,2.0,1 \mathrm{H}), 7.50(\mathrm{~d}, J=9.0,1 \mathrm{H}), 7.43$ (d, J=0.9,1H), 7.24 (d, J=2.6, 1H), 7.01 (dd, J=9.0, 2.6, 1H), 5.44 (qd, J=6.3, 4.3, 1H), 4.78 (dd, J=5.4, 3.3, 3H), 3.07 (t, J=2.4, 1H), $1.51(\mathrm{~d}, J=6.3,3 \mathrm{H}) .{ }^{13} \mathrm{C}$ NMR $\left(101 \mathrm{MHz}\right.$, Acetone- $\left.d_{6}\right) \delta=155.31,151.46,147.54,144.47,135.62,130.29,129.66,125.82,124.45$, $124.30,116.12,112.69,112.20,106.20,105.94,79.84,77.00,65.57,65.47,57.00,25.45,25.39$.

Activated alkyne photocage 18. Compound $17(0.42 \mathrm{mmol}, 0.151 \mathrm{~g})$ was dissolved in anhydrous DMF $(2.2 \mathrm{~mL}, 0.2 \mathrm{M})$ under a<smiles>C#CCOc1ccc2oc(-c3ccc([N+](=O)[O-])c([C@@H](C)OC(=O)ON4C(=O)CCC4=O)c3)cc2c1</smiles>
nitrogen atmosphere. Disuccinimidyl carbonate $(0.63 \mathrm{mmol}, 0.16 \mathrm{~g})$ and triethylamine $(1.3 \mathrm{mmol}, 0.18 \mathrm{~mL})$ were added and the reaction mixture was stirred at r.t. overnight. TLC analysis indicated complete conversion of the starting material (30\% EtOAc in Pnt, $\left.\mathrm{R}_{\mathrm{f}}=0.4\right)$. The mixture was concentrated in vacuo and diluted with $\mathrm{H}_{2} \mathrm{O}$. The aqueous layer was extracted with $\mathrm{DCM}(3 \mathrm{x})$ after which the combined organic layers were washed with brine $(1 \mathrm{x})$, dried over $\mathrm{MgSO}_{4}$ and concentrated in vacuo. The crude product was adsorbed on Celite. Purification with silica gel column chromatography (DCM $\rightarrow 0.25 \% \mathrm{MeOH}$ in DCM) yielded compound 18 (0.30 mmol, $143 \mathrm{mg}, 71 \%)$. ${ }^{1} \mathrm{H}-\mathrm{NMR}\left(400 \mathrm{MHz}\right.$, DMSO- $\left.d_{6}\right): \delta=8.21(\mathrm{~d}, J=1.7,1 \mathrm{H}), 8.19(\mathrm{~d}, J=8.7,1 \mathrm{H}), 8.14(\mathrm{dd}, J=$ 
8.6, 1.8, 1H), $7.80(\mathrm{~s}, 1 \mathrm{H}), 7.65(\mathrm{~d}, J=9.0,1 \mathrm{H}), 7.32(\mathrm{~d}, J=2.6,1 \mathrm{H}), 7.06(\mathrm{dd}, J=9.0,2.6,1 \mathrm{H}), 6.34(\mathrm{q}, J=6.4,1 \mathrm{H}), 4.86(\mathrm{~d}, J=2.3$, $2 \mathrm{H}), 3.59(\mathrm{t}, J=2.3,1 \mathrm{H}), 2.79(\mathrm{~d}, J=14.0,4 \mathrm{H}), 1.81(\mathrm{~d}, J=6.5,2 \mathrm{H})$.

Tert-butyl photocage 19. Compound $16(0,154 \mathrm{~g} ; 0,51 \mathrm{mmol})$ was dissolved in dry DMF $(1,7 \mathrm{~mL})$ in nitrogen atmosphere. $\mathrm{K}_{2} \mathrm{CO}_{3}$<smiles>C[C@@H](O)c1cc(-c2cc3cc(OCC(=O)OC(C)(C)C)ccc3o2)ccc1[N+](=O)[O-]</smiles>
$(0.62 \mathrm{mmol}, 0.083 \mathrm{~g})$ and $t$-butyl bromoacetate $(0.95 \mathrm{mmol}, 0.14 \mathrm{~mL})$ were added and the reaction was stirred at $70^{\circ} \mathrm{C}$ for $3 \mathrm{~h}$. TLC analysis indicated complete conversion of the starting material $\left(30 \%\right.$ EtOAc in $\left.\mathrm{Pnt}, \mathrm{R}_{\mathrm{f}}=0.8\right)$. The reaction mixture was poured into $\mathrm{H}_{2} \mathrm{O}$ and extracted with EtOAc (3x). The combined organic layers were washed with $\mathrm{H}_{2} \mathrm{O}(1 \mathrm{x})$ and brine (1x), dried over $\mathrm{MgSO}_{4}$ and concentrated in vacuo. Purification with silica gel column chromatography (20\% EtOAc in Pnt) yielded compound $19(0.36 \mathrm{mmol}, 0.149 \mathrm{~g}, 72 \%)$. ${ }^{1} \mathrm{H} \mathrm{NMR}(300 \mathrm{MHz}, \mathrm{Chloroform}-d) \delta=$ $8.25(\mathrm{~d}, J=2.0,1 \mathrm{H}), 7.96(\mathrm{~d}, \mathrm{~J}=8.6,1 \mathrm{H}), 7.72(\mathrm{dd}, \mathrm{J}=8.6,1.9,1 \mathrm{H}), 7.43-7.33(\mathrm{~m}, 1 \mathrm{H}), 7.06(\mathrm{~d}, J=0.9,1 \mathrm{H}), 7.00-6.89(\mathrm{~m}, 2 \mathrm{H}), 5.52$ (q, J=6.3, 1H), $4.51(\mathrm{~s}, 2 \mathrm{H}), 3.02(\mathrm{~s}, 1 \mathrm{H}), 1.60(\mathrm{~d}, \mathrm{~J}=6.3,3 \mathrm{H}), 1.50(\mathrm{~s}, 9 \mathrm{H}) \cdot{ }^{13} \mathrm{C} \mathrm{NMR}\left(75 \mathrm{MHz}, \mathrm{CDCl}_{3}\right) \delta=168.35,154.62,154.30$, $150.83,146.41,142.82,135.33,129.24,125.38,123.69,123.61,115.11,112.10,105.10,104.91,82.62,66.63,65.70,53.56,28.11$, 24.57.

Carboxylic acid photocage 11. Compound $19(0.21 \mathrm{mmol}, 0.086 \mathrm{~g})$ was dissolved in DCM $(2 \mathrm{~mL})$. Trifluoroacetic acid $(2 \mathrm{~mL})$ was<smiles>C[C@H](O)c1cc(-c2cc3cc(OCC(=O)O)ccc3o2)ccc1[N+](=O)[O-]</smiles>
added and the reaction was stirred at r.t. for $30 \mathrm{~min}$. TLC analysis indicated complete conversion of the starting material ( $30 \%$ EtOAc in Pnt, $\left.R_{f}=0.1\right)$. The mixture was concentrated in vacuo. Co-evaporation with $\mathrm{DCM}(3 \mathrm{x})$, toluene $(3 \mathrm{x})$ and $\mathrm{CHCl}_{3}(1 \mathrm{x})$ yielded compound 11 (0.21 mmol, $0.075 \mathrm{~g}$, quant.). ${ }^{1} \mathrm{H}-\mathrm{NMR}\left(400 \mathrm{MHz}, \mathrm{DMSO}-d_{6}\right) \delta=$ $13.03(\mathrm{~s}, 1 \mathrm{H}), 8.32$ (d, $J=1.7 \mathrm{~Hz}, 1 \mathrm{H}$ ), 8.05 (d, $J=8.6 \mathrm{~Hz}, 1 \mathrm{H}), 8.00$ (dd, $J=8.6,1.8 \mathrm{~Hz}$, $1 \mathrm{H}), 7.65(\mathrm{~s}, 1 \mathrm{H}), 7.62(\mathrm{~d}, J=9.1 \mathrm{~Hz}, 1 \mathrm{H}), 7.19(\mathrm{~d}, J=2.6 \mathrm{~Hz}, 1 \mathrm{H}), 7.01(\mathrm{dd}, J=8.9,2.6 \mathrm{~Hz}, 1 \mathrm{H}), 5.66(\mathrm{~s}, 1 \mathrm{H}), 5.25(\mathrm{q}, J=6.3 \mathrm{~Hz}$, 1H), $4.73(\mathrm{~s}, 2 \mathrm{H}), 1.44$ (d, $J=6.3 \mathrm{~Hz}, 3 \mathrm{H}) .{ }^{13} \mathrm{C}-\mathrm{NMR}(100 \mathrm{MHz}$, DMSO-d $)$ : $\delta$ 170.36, 154.52, 153.93, 149.96, 143.60, 134.22, 129.11, $125.17,123.88,123.17,115.02,112.09,105.68,104.86,65.19,64.02,25.09$.

Tert-butyl lysine photocage 20. Compound $19(0.17 \mathrm{mmol}, 0.070 \mathrm{~g})$ was dissolved in acetonitrile $(1 \mathrm{~mL})$. N,N'-disuccinimidyl<smiles>COC(=O)[C@H](CCCCNC(=O)OC(C)c1cc(-c2cc3cc(OCC(=O)OC(C)(C)C)ccc3o2)ccc1[N+](=O)[O-])C(=O)NC(C)(C)C</smiles>
carbonate $(0.50 \mathrm{mmol}, 0.13 \mathrm{~g})$ and DiPEA $(0.30 \mathrm{mmol}, 52 \mu \mathrm{L})$ were added and the mixture was stirred for $16 \mathrm{~h}$ at r.t. The reaction mixture was poured in a $50 \%$ brine solution which was washed with EtOAc $(3 \mathrm{x})$. The combined organic layers were washed with brine $(1 \mathrm{x})$, dried $\left(\mathrm{MgSO}_{4}\right)$ and concentrated in vacuo. The concentrate was reconstituted in DMF $(2 \mathrm{~mL})$ and boc-Lys-OMe.HOAc $(0.50 \mathrm{mmol}, 0.13 \mathrm{~g})$ and DiPEA $(1.0 \mathrm{mmol}, 174 \mu \mathrm{L})$ was added. The reaction mixture was stirred for $15 \mathrm{~min}$ at r.t.. TLC analysis indicated complete conversion of the starting material $(5 \% \mathrm{MeOH}$ in $\mathrm{DCM}, \mathrm{R}_{\mathrm{f}}=0.6$ ). The reaction mixture was poured in a $50 \%$ brine solution which was washed with EtOAc (3x). The combined organic layers were washed with $0.1 \mathrm{M} \mathrm{HCl}\left(\right.$ aq.) $(2 \mathrm{x})$, brine (3x), dried $\left(\mathrm{MgSO}_{4}\right)$ and concentrated in vacuo. Purification with silica gel column chromatography (DCM $\rightarrow 0.5 \% \mathrm{MeOH}$ in DCM) yielded compound 20 (0.093 mmol, $0.065 \mathrm{~g}, 55 \%)$. ${ }^{1} \mathrm{H}$ NMR $(400 \mathrm{MHz}$, Chloroform- $d) \delta=8.08-7.99(\mathrm{~m}, 2 \mathrm{H}), 7.81(\mathrm{dt}, J=8.6,1.8,1 \mathrm{H}), 7.46(\mathrm{~d}, J=8.9,1 \mathrm{H}), 7.18-7.13(\mathrm{~m}, 1 \mathrm{H}), 7.08-$ $6.98(\mathrm{~m}, 2 \mathrm{H}), 6.33(\mathrm{qd}, \mathrm{J}=6.4,3.3,1 \mathrm{H}), 5.08(\mathrm{t}, \mathrm{J}=8.4,2 \mathrm{H}), 4.57(\mathrm{~s}, 2 \mathrm{H}), 4.30-4.24(\mathrm{~m}, 1 \mathrm{H}), 3.70(\mathrm{~d}, \mathrm{~J}=4.1,3 \mathrm{H}), 3.13(\mathrm{ddq}, \mathrm{J}=23.7$, 12.0, 6.6, 1H), $1.84-1.72(\mathrm{~m}, \mathrm{OH}), 1.86-1.54(\mathrm{~m}, 3 \mathrm{H}), 1.51(\mathrm{~s}, 10 \mathrm{H}), 1.44(\mathrm{~d}, \mathrm{~J}=4.9,9 \mathrm{H}), 1.40-1.22(\mathrm{~m}, 3 \mathrm{H}) .{ }^{13} \mathrm{C} \mathrm{NMR}(101 \mathrm{MHz}$, $\left.\mathrm{CDCl}_{3}\right) \delta=173.29,168.21,155.43,154.79,154.30,150.89,146.62,140.13,135.36,129.28,125.50,124.14,123.08,115.21,112.14$, $105.11,104.98,82.49,80.00,68.55,66.67,53.14,52.37,40.72,32.53,29.27,28.39,28.14,22.50,22.34$.

Alkyne lysine photocage 21. Compound $18(0.09 \mathrm{mmol}, 0.056 \mathrm{~g})$ was dissolved in DMF (1 mL). Boc-Lys-OMe.HOAc (0.5 mmol,<smiles>C#CCOc1ccc2oc(-c3ccc([N+](=O)[O-])c(C(C)OC(=O)NCCCCC(NC(=O)O)C(=O)O)c3)cc2c1</smiles>
$0.130 \mathrm{~g})$ and DiPEA $(1 \mathrm{mmol}, 174 \mu \mathrm{L})$ was added. The reaction mixture was stirred for $15 \mathrm{~min}$ at r.t.. TLC analysis indicated complete conversion of the starting material $\left(5 \% \mathrm{MeOH}\right.$ in $\left.\mathrm{DCM}, \mathrm{R}_{\mathrm{f}}=0.6\right)$. The reaction mixture was poured in a $50 \%$ brine solution which was washed with EtOAc $(3 \mathrm{x})$. The combined organic layers were washed with $0.1 \mathrm{M} \mathrm{HCl}$ (aq.) (2x), brine $(3 \mathrm{x})$, dried $\left(\mathrm{MgSO}_{4}\right)$ and concentrated in vacuo. Purification with silica gel column chromatography (DCM $\rightarrow 0.5 \% \mathrm{MeOH}$ in $\mathrm{DCM}$ ) yielded compound 21 (0.059 mmol, $0.037 \mathrm{~g}, 66 \%) .{ }^{1} \mathrm{H}$ NMR $(400 \mathrm{MHz}$, Chloroform- $d$ ) $\delta=8.08-8.00(\mathrm{~m}, 2 \mathrm{H}), 7.82(\mathrm{dt}, \mathrm{J}=8.5$, 
1.8, 1H), 7.47 (d, J=8.9, 1H), 7.18 (t, J=3.3, 2H), 7.03 (ddd, J=9.0, 2.6, 1.0, 1H), 6.33 (qd, J=6.4, 3.4, 1H), 5.06 (d, J=8.4, $1 \mathrm{H}$ ), 5.00 (d, J=6.9, 1H), 4.75 (d, J=2.4, 2H), 4.27 (d, J=7.0,1H), 3.70 (d, J=5.1,3H), 3.13 (ddd, J=35.2, 13.1, 6.8, 1H), 3.13 (s, 1H), $2.56(\mathrm{t}$, $J=2.4,1 \mathrm{H}), 1.74(\mathrm{~s}, 1 \mathrm{H}), 1.68(\mathrm{dd}, J=6.5,1.8,3 \mathrm{H}), 1.44(\mathrm{~d}, J=5.0,11 \mathrm{H}), 1.36(\mathrm{td}, J=10.1,9.0,4.0,2 \mathrm{H}), 1.26(\mathrm{~s}, 1 \mathrm{H}) .{ }^{13} \mathrm{C} \mathrm{NMR}(101$ $\left.\mathrm{MHz}, \mathrm{CDCl}_{3}\right) \delta=155.43,154.35,150.98,146.66,140.18,135.39,129.30,125.56,124.17,123.09,115.56,112.16,105.53,105.05$, $78.74,75.75,56.79,53.15,52.42,40.77,32.60,28.43,22.52,22.37$.

Lysine photocage 22. NPBF-pNP $(0.045 \mathrm{mmol}, 0.020 \mathrm{~g})$ was dissolved in DMF $(1 \mathrm{~mL})$. Boc-Lys-OMe.HOAc $(0.076 \mathrm{mmol}, 0.020 \mathrm{~g})$<smiles>COC(=O)OC(=O)N[C@@H](CCCCNC(=O)OC(C)c1cc(-c2cc3ccccc3o2)ccc1[N+](=O)[O-])C(=O)OCc1ccccc1</smiles>
and DiPEA $(0.135 \mathrm{mmol}, 24 \mu \mathrm{L})$ were added and the mixture was stirred for $16 \mathrm{~h}$ at r.t.. TLC analysis indicated complete conversion of the starting material $\left(5 \% \mathrm{MeOH}\right.$ in $\left.\mathrm{DCM}, \mathrm{R}_{\mathrm{f}}=0.8\right)$. The reaction mixture was poured in $0.1 \mathrm{M} \mathrm{HCl}$ (aq.) and washed with $\mathrm{DCM}(3 \mathrm{x})$. The combined organic layers were washed with a saturated solution of $\mathrm{NaHCO}_{3}$ (aq.) (3x), dried $\left(\mathrm{MgSO}_{4}\right)$ and concentrated in vacuo. Purification with silica gel column chromatography (DCM $\rightarrow 0.5 \% \mathrm{MeOH}$ in DCM) yielded compound $22(0.035 \mathrm{mmol}, 0.020 \mathrm{~g}, 78 \%) .{ }^{1} \mathrm{H}$ $\operatorname{NMR}\left(300 \mathrm{MHz}\right.$, DMSO- $\left.\mathrm{d}_{6}\right) \delta=8.14-8.02(\mathrm{~m}, 2 \mathrm{H}), 7.87(\mathrm{dt}, J=8.7,1.5,1 \mathrm{H}), 7.66(\mathrm{~d}, J=7.7,1 \mathrm{H}), 7.59(\mathrm{~d}$, $J=8.2,1 \mathrm{H}), 7.45-7.15(\mathrm{~m}, 4 \mathrm{H}), 6.42-6.31(\mathrm{~m}, 1 \mathrm{H}), 5.06(\mathrm{~d}, J=8.4,1 \mathrm{H}), 4.99(\mathrm{~s}, 1 \mathrm{H}), 4.28(\mathrm{~d}, J=5.6,1 \mathrm{H})$, $3.72(\mathrm{~d}, \mathrm{~J}=3.3,3 \mathrm{H}), 3.15$ (tt, J=13.5, 6.8, 2H), $1.71(\mathrm{~d}, \mathrm{~J}=6.5,3 \mathrm{H}), 1.68-1.50(\mathrm{~m}, 1 \mathrm{H}), 1.46(\mathrm{~d}, \mathrm{~J}=3.6,10 \mathrm{H}), 1.27(\mathrm{~s}, 5 \mathrm{H}), 0.95-0.82$ $(\mathrm{m}, 2 \mathrm{H})$.

B) Synthesis of bis-functionalized ortho-nitrobenzoyl photoprotecting group<smiles>CC1Oc2cc(C=O)c([N+](=O)[O-])cc2O1</smiles>

23

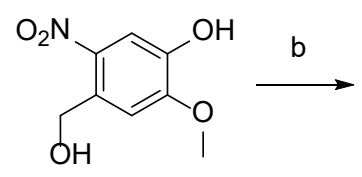

24<smiles>CCCCC(=O)COc1cc([N+](=O)[O-])c(CO)cc1OC</smiles>

25<smiles>COc1cc(COC(=O)Oc2ccc([N+](=O)[O-])cc2)c([N+](=O)[O-])cc1OCC(=O)O</smiles>

26

Scheme S2. Synthesis of photocage 26. Reagents and conditions: a) i. $\mathrm{NaBH}_{4}, \mathrm{EtOH}$; ii. $\mathrm{NaOMe}, \mathrm{MeOH}, \mathrm{DMSO}, 120{ }^{\circ} \mathrm{C}, 2 \mathrm{~h}, 27 \%$; b) tert-butyl 2-bromoacetate, $\mathrm{K}_{2} \mathrm{CO}_{3}, 90^{\circ} \mathrm{C}$, DMF, $2 \mathrm{~h}$, quant.; c) i. p-nitrophenylcholoroformate, $\mathrm{ACN}$, pyridine, $\mathrm{N}_{2}, 0^{\circ} \mathrm{C}$-rt, $18 \mathrm{~h}$; ii. TFA/DCM (1:1), 2h, rt, quant.

4-(hydroxymethyl)-2-methoxy-5-nitrophenol (24). 6-nitropiperonal 23 (50 mmol, $9.7 \mathrm{~g}$ ) was dissolved in EtOH (75 mL) and cooled<smiles>COc1cc(CO)c([N+](=O)[O-])cc1O</smiles>
to $0{ }^{\circ} \mathrm{C} . \mathrm{NaBH}_{4}(60 \mathrm{mmol}, 2.28 \mathrm{~g})$ was added slowly and reaction was stirred for $3 \mathrm{~h}$. A saturated solution of $\mathrm{NH}_{4} \mathrm{Cl}$ in $\mathrm{H}_{2} \mathrm{O}$ was slowly added and the mixture was then extracted with $\mathrm{DCM}(4 \mathrm{x})$, dried over $\mathrm{MgSO}_{4}$, filtered and concentrated. The crude alcohol was then directly dissolved in MeOH:DMSO (1:2, v:v) and NaOMe (150 mmol, $8.1 \mathrm{~g}$ ) was added. After stirring at $120^{\circ} \mathrm{C}$ for $2 \mathrm{~h}$, the solution was cooled to $0{ }^{\circ} \mathrm{C}$ and $1 \mathrm{M} \mathrm{HCl}$ was added. The $\mathrm{H}_{2} \mathrm{O}$ layer was extracted with DCM $(3 \mathrm{x})$, washed with $\mathrm{H}_{2} \mathrm{O}(1 \mathrm{x})$, dried $\left(\mathrm{MgSO}_{4}\right)$, filtered and concentrated. Finally, the crude was purified by flash column chromatography over silica gel (EtOAc in Pnt - 0\% to 50\% v/v) to provide $24(13.5 \mathrm{mmol}, 2.69 \mathrm{~g}, 27 \%) .{ }^{1} \mathrm{H}$ NMR (400 MHz, DMSO-d6) $\delta 7.55$ (s, 1H), 7.33 (s, 1H), 5.51 (s, 1H), 4.79 (s, 2H), $3.90(\mathrm{~s}, 2 \mathrm{H}) .{ }^{13} \mathrm{C}$ NMR (75 MHz, DMSO-d6) $\delta$ $152.9,145.0,132.4,111.3,110.0,60.2,55.9$.

Tert-butyl 2-(4-(hydroxymethyl)-2-methoxy-5-nitrophenoxy)acetate (25). Compound 24 (5 mmol, $1.03 \mathrm{~g}$ ) was dissolved in DMF<smiles>CCCCOC(=O)COc1cc([N+](=O)[O-])c(CO)cc1OC</smiles>
$(50 \mathrm{~mL})$ and $\mathrm{K}_{2} \mathrm{CO}_{3}(5 \mathrm{mmol}, 0.7 \mathrm{~g})$ was added. Tert-butyl 2-bromoacetate $(5.5 \mathrm{mmol}, 1.1 \mathrm{~g})$ was added and the reaction mixture was stirred at $90^{\circ} \mathrm{C}$ for 2 hour. The mixture was extracted with $\mathrm{Et}_{2} \mathrm{O}$ and washed with $\mathrm{HCl} 1 \mathrm{M}$. The organic layer was finally washed with brine and the dried over $\mathrm{Na}_{2} \mathrm{SO}_{4}$ to give as 25 yellow crystals $(5.0$ mmol, $1.5 \mathrm{~g}$, quant.). ${ }^{1} \mathrm{H}$ NMR (400 MHz, MeOD): $\delta=1.52$ (s, 9H), 4.01 (s, 3H), 4.72 (s, 2H), 4.98 (s, 2H), 7.48 (s, $1 \mathrm{H}), 7.70(\mathrm{~s}, 1 \mathrm{H}) \mathrm{ppm}$. 
4-((tert-butoxycarbonyl)methoxy)-5-methoxy-2-nitrobenzyl 4-nitrophenyl carbonate (26). Compound 25 (0.16 mmol, $50 \mathrm{mg})$<smiles>COc1cc(COC(=O)Oc2ccc([N+](=O)[O-])cc2)c([N+](=O)[O-])cc1OCC(=O)O</smiles>

was dissolved in $\mathrm{ACN}$ and pyridine $(0.8 \mathrm{mmol}, 0.06 \mathrm{~mL})$ was added dropwise while stirring under $\mathrm{N}_{2}$. Nitrophenyl chloroformate $(0.16 \mathrm{mmol}, 32 \mathrm{mg})$ was added and the solution was stirred overnight. The mixture was extracted with DCM and washed with brine. The organic layer was dried over $\mathrm{Na}_{2} \mathrm{SO}_{4}$ and the crude product was purified by column chromatography to give tert-butyl protected 26 a as a yellow solid. ${ }^{1} \mathrm{H}$ NMR $(400 \mathrm{MHz}$, $\left.\mathrm{CDCl}_{3}\right): \delta=1.51(\mathrm{~s}, 9 \mathrm{H}), 4.02(\mathrm{~s}, 3 \mathrm{H}), 4.68(\mathrm{~s}, 2 \mathrm{H}), 5.71(\mathrm{~s}, 2 \mathrm{H}), 7.14(\mathrm{~s}, 1 \mathrm{H}), 7.41$ (dd, $\left.J=9.2 \mathrm{~Hz}, 2 \mathrm{H}\right), 7.68(\mathrm{~s}, 1 \mathrm{H}), 8.30(\mathrm{dd}, J=9.2$ $\mathrm{Hz}, 2 \mathrm{H}$ ). The carbonate was then deprotected by dissolving it in 1:1 mixture of DCM:TFA. The mixture was stirred at r.t. for $2 \mathrm{~h}$. The solvent was removed under reduced pressure followed by co-evaporation with toluene to give $\mathbf{2 6}$ as a yellow solid $(0.16 \mathrm{mmol}, 78$ mg, quant.). ${ }^{1} \mathrm{H} \operatorname{NMR}\left(400 \mathrm{MHz}, \mathrm{CD}_{3} \mathrm{CN}\right): \delta=3.97(\mathrm{~s}, 3 \mathrm{H}), 4.76(\mathrm{~s}, 2 \mathrm{H}), 5.62(\mathrm{~s}, 2 \mathrm{H}), 7.21(\mathrm{~s}, 1 \mathrm{H}), 7.47(\mathrm{~d}, J=9.2 \mathrm{~Hz}, 2 \mathrm{H}), 7.68(\mathrm{~s}$, $1 \mathrm{H}$ ), $8.29(\mathrm{~d}, J=9.1 \mathrm{~Hz}, 2 \mathrm{H}) \mathrm{ppm}$. LC-MS (linear gradient $10 \rightarrow 90 \% \mathrm{MeCN}, 0.1 \% \mathrm{TFA}, 15 \mathrm{~min}): \mathrm{Rt}(\mathrm{min}): 5.31$ (ESI-MS (m/z): $\left.422.13\left(\mathrm{M}+\mathrm{H}^{+}\right)\right)$.

C) Synthesis of cyclohexylalanine warhead

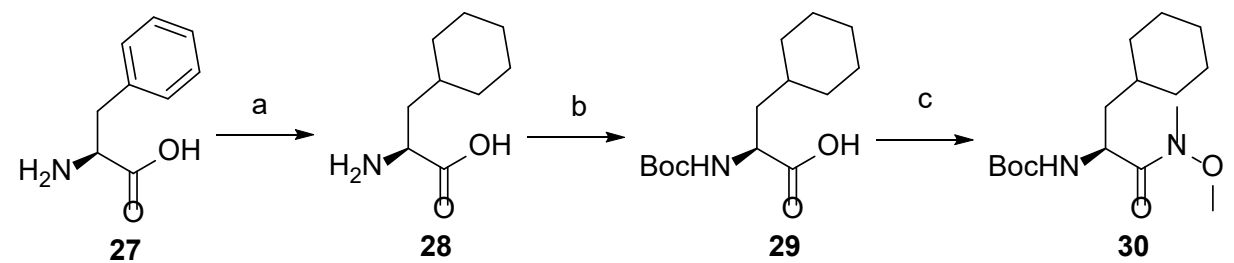

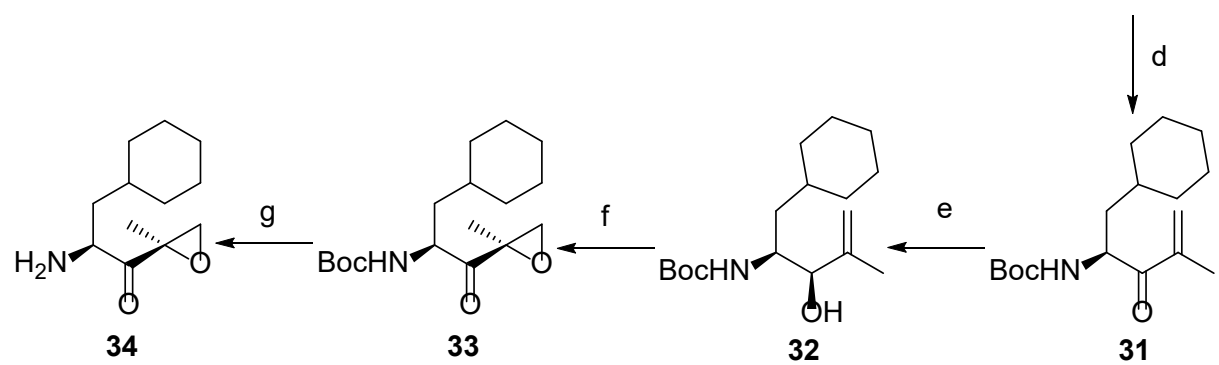

Scheme S3. Synthesis of epoxyketone warhead 34. Reagents and conditions: a) $\mathrm{PtO}_{2}, 80$ bar $\mathrm{H}_{2}, \mathrm{AcOH}_{2} \mathrm{H}_{2} \mathrm{O}, 7 \mathrm{~d}, 98 \%$; b) $\mathrm{Boc} 2 \mathrm{O}$, sat. aq. $\mathrm{NaHCO}_{3}$, THF, 2 d, 46\%; c) N,O-dimethylhydroxylamine, HCTU, DIPEA, DCM, 16 h, 96\%; d) 2-bromopropene, t-BuLi, THF, $78{ }^{\circ} \mathrm{C}, 4 \mathrm{~h}, 50 \%$, e) $\mathrm{CeCl}_{3} \cdot 7 \mathrm{H}_{2} \mathrm{O}, \mathrm{NaBH}_{4}, \mathrm{MeOH}, 0{ }^{\circ} \mathrm{C}, 90 \mathrm{~min}$, quant.; f) i. $\mathrm{VO}(\mathrm{acac})_{2}, \mathrm{t}-\mathrm{BuOOH}, \mathrm{DCM}, 0{ }^{\circ} \mathrm{C}, 2 \mathrm{~h}$; ii. DMP, DCM, $0{ }^{\circ} \mathrm{C}$, $16 \mathrm{~h} 85 \%$; g) TFA, DCM, 1 h, $56 \%$.

$\mathbf{H}_{2} \mathrm{~N}$-Cha-OH (28). Inside of a $500 \mathrm{~mL}$ pressure vessel, L-phenylalanine 27 (90.8 mmol, $15.0 \mathrm{~g}$ ) and platinum(IV) oxide (3.1 mmol,<smiles>NC(CC1CCCCC1)C(=O)O</smiles>
$0.70 \mathrm{~g}$ ) were dissolved in $\mathrm{MeOH}(40 \mathrm{~mL})$ and $2 \mathrm{M}$ aq. $\mathrm{HCl}(4 \mathrm{~mL})$. The vessel was then placed in a autoclave hydrogenator and the L-phenylalanine was hydrogenated under a hydrogen gas pressure of 80 bar at r.t. while stirring for $7 \mathrm{~d}$, after which the reaction mixture was diluted with methanol (125 mL) and $\mathrm{H}_{2} \mathrm{O}(125 \mathrm{~mL})$. Now the diluted reaction mixture was filtered over a plug of celite and an equal volume of $\mathrm{Et}_{2} \mathrm{O}$ was then added to the filtrate, followed by vigorous stirring of the solution for three $d$ at r.t.. The mixture was then stirred in $2 \mathrm{M} \mathrm{HCl}$ overnight at $60^{\circ} \mathrm{C}$. Concentration in vacuo to gave $\mathrm{H}_{2} \mathrm{~N}-\mathrm{Cha}-\mathrm{OH} 28(89.2 \mathrm{mmol}, 15.2 \mathrm{~g}, 98 \%) .{ }^{1} \mathrm{H} \mathrm{NMR}(400 \mathrm{MHz}, \mathrm{MeOD}) \delta 3.62(\mathrm{~s}$, $1 \mathrm{H}), 1.86-0.87(\mathrm{~m}, 13 \mathrm{H}) .{ }^{13} \mathrm{C}$ NMR (101 MHz, MeOD) $\delta 181.10,51.92,40.12,33.34,33.12,25.84,25.63$. LC-MS (linear gradient 10 $\rightarrow 90 \% \mathrm{MeCN}, 0.1 \% \mathrm{TFA}, 15 \mathrm{~min}): \mathrm{Rt}(\mathrm{min}): 5.13$ (ESI-MS (m/z): $172.18\left(\mathrm{M}+\mathrm{H}^{+}\right)$). HRMS: calculated for $\mathrm{C}_{9} \mathrm{H}_{17} \mathrm{NO}_{2} 172.12593$ $[\mathrm{M}+\mathrm{H}]^{+}$; found 172.12534 . 
Boc-Cha-OH (29). A stirred solution of $\mathrm{H}_{2} \mathrm{~N}-\mathrm{Cha}-\mathrm{OH} 28$ (85.1 mmol, $\left.14.6 \mathrm{~g}\right)$ in saturated aqueous $\mathrm{NaHCO}_{3}(122 \mathrm{~mL})$ was cooled to<smiles>CC(C)(C)OC(=O)N[C@@H](CC1CCCCC1)C(=O)O</smiles>
$0{ }^{\circ} \mathrm{C}$ in an ice bath. Then a solution of di-tert-butyl dicarbonate $(20.7 \mathrm{~g}, 95.1 \mathrm{mmol})$ in THF $(50 \mathrm{~mL})$ was added and the reaction mixture was allowed to stir for $2 \mathrm{~d}$ at r.t.. The mixture was then placed under vacuum to remove THF. Now the aqueous solution was acidified to $\mathrm{pH}=3$ with $3 \mathrm{M} \mathrm{HCl}$. Consequently, the aqueous phase was extracted with EtOAc (3x), after which the combined organic layers were washed with brine (1x), dried over $\mathrm{Na}_{2} \mathrm{SO}_{4}$, filtered and concentrated. Co-evaporation with toluene (1x) and $\mathrm{CHCl}_{3}(3 \mathrm{x})$ then yielded Boc-Cha-OH 29 (39.3 mmol, $10.7 \mathrm{~g}, 46 \%) .{ }^{1} \mathrm{H}$ NMR $\left(400 \mathrm{MHz}, \mathrm{CDCl}_{3}\right) \delta 9.99(\mathrm{~s}, 1 \mathrm{H}), 4.88(\mathrm{~d}, J=8.4 \mathrm{~Hz}, 1 \mathrm{H}), 4.41-4.27(\mathrm{~m}, 1 \mathrm{H}), 1.82(\mathrm{~d}, J=11.8$ $\mathrm{Hz}, 1 \mathrm{H}), 1.76-1.58(\mathrm{~m}, 5 \mathrm{H}), 1.58-1.48(\mathrm{~m}, 1 \mathrm{H}), 1.45(\mathrm{~s}, 9 \mathrm{H}), 1.30-1.08(\mathrm{~m}, 3 \mathrm{H}), 1.03-0.83(\mathrm{~m}, 2 \mathrm{H}) .{ }^{13} \mathrm{C} \mathrm{NMR}(101 \mathrm{MHz}, \mathrm{CDCl} 3)$ $\delta 178.70,155.81,80.34,51.47,40.12,34.16,33.68,32.51,28.44,26.51,26.32,26.14$. LC-MS (linear gradient $10 \rightarrow 90 \% \mathrm{MeCN}$, 0.1\% TFA, $15 \mathrm{~min})$ : Rt (min): $8.43\left(\right.$ ESI-MS (m/z): $\left.272.33\left(\mathrm{M}+\mathrm{H}^{+}\right)\right)$. HRMS: calculated for $\mathrm{C}_{14} \mathrm{H}_{25} \mathrm{NO}_{4} 272.17836[\mathrm{M}+\mathrm{H}]^{+} ;$found 272.17889 .

Boc-Cha-N(OMe)Me (30). To a solution of 29 (10.0 mmol, $2.72 \mathrm{~g})$ in anhydrous DCM (100 mL) were added HCTU (12.0 mmol, 4.96<smiles>CON1C(=O)[C@H](NC(=O)OC(C)(C)C)CC2CCCCC21</smiles>
g), N,O-dimethylhydroxylamine hydrochloride $(20.0 \mathrm{mmol}, 1.95 \mathrm{~g})$ and DiPEA (35 mmol, $6.1 \mathrm{~mL})$. The reaction mixture was stirred for $16 \mathrm{~h}$ at r.t. and then the mixture was concentrated, leaving behind a residue that was consequently dissolved in EtOAc. Now the organic layer was washed with $1 \mathrm{M} \mathrm{HCl}(3 \mathrm{x})$, saturated aqueous $\mathrm{NaHCO}_{3}(2 \mathrm{x})$ and brine (2x), and then dried over $\mathrm{Na}_{2} \mathrm{SO}_{4}$, filtered and concentrated. Finally, the crude was purified by column chromatography over silica gel (EtOAc in Pnt $-10 \%$ to $50 \% \mathrm{v} / \mathrm{v}$ ) to give Boc-Cha-N(OMe)Me 30 (9.56 mmol, $3.00 \mathrm{~g}, 96 \%) .{ }^{1} \mathrm{H}$ NMR $\left(400 \mathrm{MHz}, \mathrm{CDCl}_{3}\right) \delta 5.02(\mathrm{~d}, \mathrm{~J}=9.2 \mathrm{~Hz}, 1 \mathrm{H}), 4.87-4.55(\mathrm{~m}, 1 \mathrm{H}), 3.78(\mathrm{~s}, 3 \mathrm{H}), 3.20(\mathrm{~s}, 3 \mathrm{H})$, $1.91(\mathrm{~d}, J=12.6 \mathrm{~Hz}, 1 \mathrm{H}), 1.82-1.55(\mathrm{~m}, 5 \mathrm{H}), 1.54-1.46(\mathrm{~m}, 1 \mathrm{H}), 1.45-1.32(\mathrm{~m}, 10 \mathrm{H}), 1.31-1.06(\mathrm{~m}, 3 \mathrm{H}), 1.04-0.82(\mathrm{~m}, 2 \mathrm{H})$. ${ }^{13} \mathrm{C}$ NMR $\left(101 \mathrm{MHz}, \mathrm{CDCl}_{3}\right) \delta 155.82,155.79,79.62,61.74,48.47,40.67,34.19,34.12,32.36,32.28,28.50,26.62,26.42,26.20$. LCMS (linear gradient $10 \rightarrow 90 \% \mathrm{MeCN}, 0.1 \%$ TFA, $15 \mathrm{~min}): \mathrm{Rt}(\mathrm{min}): 9.13\left(\mathrm{ESI}-\mathrm{MS}(\mathrm{m} / \mathrm{z}): 314.80\left(\mathrm{M}+\mathrm{H}^{+}\right)\right.$). HRMS: calculated for $\mathrm{C}_{16} \mathrm{H}_{30} \mathrm{~N}_{2} \mathrm{O}_{4} 315.22056[\mathrm{M}+\mathrm{H}]^{+}$; found 315.22781

Boc-Cha- $\mathrm{C}\left(\mathrm{CH}_{3}\right)=\mathrm{CH}_{2}$ (31). To a solution of 2-bromopropene $(1.5 \mathrm{mmol}, 0.13 \mathrm{~mL})$ in anhydrous THF $(5 \mathrm{~mL})$ at $-78{ }^{\circ} \mathrm{C}$ was added tert-butyllithium (2.30 mmol, $1.35 \mathrm{~mL}, 1.7 \mathrm{M}$ in Pnt) over $10 \mathrm{~min}$. After stirring for $15 \mathrm{~min}$ at $-78{ }^{\circ} \mathrm{C}$, Weinreb<smiles>CC1=C2CCCCC2C[C@H](NC(=O)OCc2ccccc2)C1=O</smiles>
amide $30(0.50 \mathrm{mmol}, 0.16 \mathrm{~g})$ dissolved in anhydrous $\mathrm{Et}_{2} \mathrm{O}(1.5 \mathrm{~mL})$ was added over $10 \mathrm{~min}$. The reaction mixture was stirred for $4 \mathrm{~h}$ while not allowing it to warm up beyond $-40{ }^{\circ} \mathrm{C}$, followed by quenching of the reaction with saturated aqueous $\mathrm{NH}_{4} \mathrm{Cl}(15 \mathrm{~mL})$ and allowing the mixture to attain r.t.. The solution was transferred to a separatory funnel where the aqueous layer was extracted with EtOAc $(4 \mathrm{x})$, and the combined organic layers were washed with brine $(1 \mathrm{x})$, dried over $\mathrm{Na}_{2} \mathrm{SO}_{4}$, filtered and concentrated. The crude product was purified by column chromatography over silica gel (EtOAc in Pnt - 10\% v/v) $31(0.25 \mathrm{mmol}, 0.072 \mathrm{~g}, 50 \%) .{ }^{1} \mathrm{H} \mathrm{NMR}\left(400 \mathrm{MHz}, \mathrm{CDCl}_{3}\right) \delta 6.06(\mathrm{~s}, 1 \mathrm{H})$, $5.92-5.80(\mathrm{~m}, 1 \mathrm{H}), 5.37-4.84(\mathrm{~m}, 2 \mathrm{H}), 1.99(\mathrm{~d}, \mathrm{~J}=12.4 \mathrm{~Hz}, 1 \mathrm{H}), 1.90(\mathrm{~s}, 3 \mathrm{H}), 1.76-1.50(\mathrm{~m}, 5 \mathrm{H}), 1.49-1.35(\mathrm{~m}, 10 \mathrm{H}), 1.34-$ $1.07(\mathrm{~m}, 4 \mathrm{H}), 0.99-0.82(\mathrm{~m}, 2 \mathrm{H}) .{ }^{13} \mathrm{C}$ NMR $\left(101 \mathrm{MHz}, \mathrm{CDCl}_{3}\right) \delta 201.85,155.68,142.41,126.20,79.73,52.11,41.85,34.38,34.23$, 32.56, 28.48, 26.56, 26.42, 26.22, 18.01. LC-MS (linear gradient $10 \rightarrow 90 \% \mathrm{MeCN}, 0.1 \% \mathrm{TFA}, 15 \mathrm{~min}): \mathrm{Rt}(\mathrm{min}): 9.56$ (ESI-MS (m/z): $\left.296.14\left(\mathrm{M}+\mathrm{H}^{+}\right)\right)$. HRMS: calculated for $\mathrm{C}_{17} \mathrm{H}_{29} \mathrm{NO}_{3} 296.21474[\mathrm{M}+\mathrm{H}]^{+}$; found 296.21435.

Boc-Cha-OH-C $\left(\mathrm{CH}_{3}\right)=\mathrm{CH}_{2}$ (32). To a solution of $31(0.23 \mathrm{mmol}, 0.068 \mathrm{~g})$ in anhydrous methanol $(3.3 \mathrm{~mL})$ was added $\mathrm{CeCl} 3 \cdot 7 \mathrm{H}_{2} \mathrm{O}$<smiles>CC1=C2CCCCC2C[C@H](NC(=O)OCc2ccccc2)[C@H]1O</smiles>
$(0.37 \mathrm{mmol}, 0.14 \mathrm{~g})$ and the mixture was stirred at r.t.. Once the solution was clear, the mixture was cooled to 0 ${ }^{\circ} \mathrm{C}$ and $\mathrm{NaBH}_{4}(0.32 \mathrm{mmol}, 0.012 \mathrm{~g})$ was added in small portions over $10 \mathrm{~min}$. After stirring for $90 \mathrm{~min}$ at $0{ }^{\circ} \mathrm{C}$, the reaction was quenched by the addition of acetic acid $(5 \mathrm{~mL})$ and the mixture was left to stir for 30 min while coming to r.t.. Now toluene was added and the mixture was concentrated under reduced pressure. The resulting residue was redissolved in a $1: 1 \mathrm{H}_{2} \mathrm{O} / \mathrm{EtOAc}$ mixture, which was transferred to a separatory funnel, and the aqueous layer was extracted with EtOAc (3x). The combined organic layers were washed with brine (1x), dried over $\mathrm{Na}_{2} \mathrm{SO}_{4}$, filtered and concentrated to obtain $32\left(0.23 \mathrm{mmol}, 0.070 \mathrm{~g}\right.$, quant.). ${ }^{1} \mathrm{H}$ NMR $\left(400 \mathrm{MHz}, \mathrm{CDCl}_{3}\right) \delta 5.01(\mathrm{~s}, 1 \mathrm{H}), 4.94-4.91(\mathrm{~m}, 1 \mathrm{H}), 4.74(\mathrm{~d}, J$ $=9.1 \mathrm{~Hz}, 1 \mathrm{H}), 4.20-4.11(\mathrm{~m}, 1 \mathrm{H}), 3.93-3.83(\mathrm{~m}, 1 \mathrm{H}), 1.86(\mathrm{~d}, J=12.2 \mathrm{~Hz}, 1 \mathrm{H}), 1.75(\mathrm{~s}, 3 \mathrm{H}), 1.70-1.56(\mathrm{~m}, 4 \mathrm{H}), 1.49-1.42(\mathrm{~m}$, $10 \mathrm{H}), 1.24-1.10(\mathrm{~m}, 5 \mathrm{H}), 0.99-0.87(\mathrm{~m}, 1 \mathrm{H}), 0.87-0.71(\mathrm{~m}, 1 \mathrm{H}) .{ }^{13} \mathrm{C} \mathrm{NMR}\left(101 \mathrm{MHz}, \mathrm{CDCl}_{3}\right) \delta 156.22,145.01,111.30,79.42$, $77.89,50.33,35.80,34.56,34.12,32.35,28.49,26.67,26.56,26.25,19.59$. LC-MS (linear gradient $10 \rightarrow 90 \%$ MeCN, 0.1\% TFA, 15 min): Rt (min): 9.43 (ESI-MS (m/z): $298.33\left(\mathrm{M}+\mathrm{H}^{+}\right)$). HRMS: calculated for $\mathrm{C}_{17} \mathrm{H}_{31} \mathrm{NO}_{3} 298.23039$ [M+H] $]^{+}$found 298.23134 . 
Boc-Cha-EK (33). To a solution of $32(0.23 \mathrm{mmol}, 0.070 \mathrm{~g})$ in anhydrous DCM $(2.3 \mathrm{~mL})$ at $0{ }^{\circ} \mathrm{C}$ was added vanadyl acetylacetonate<smiles>CC(C)(C)OC(=O)N[C@@H](CC1CCCCC1)C(=O)[C@]1(C)CO1</smiles>
$(0.02 \mathrm{mmol}, 0.006 \mathrm{~g})$, followed by the addition of tert-butyl hydroperoxide $(0.72 \mathrm{mmol}, 0.13 \mathrm{~mL}, 5.5 \mathrm{M}$ in decane). The reaction mixture was stirred at $0{ }^{\circ} \mathrm{C}$ for $2 \mathrm{~h}$, and then the mixture was concentrated and the residue redissolved in EtOAc. Now the organic layer was washed with saturated aqueous $\mathrm{NaHCO}_{3}(2 \mathrm{x}), \mathrm{H}_{2} \mathrm{O}$ (1x) and brine (1x), and consequently dried over $\mathrm{Na}_{2} \mathrm{SO}_{4}$, filtered and concentrated. A solution of the crude product in anhydrous $\mathrm{DCM}(2.3 \mathrm{~mL})$ was cooled to $0{ }^{\circ} \mathrm{C}$, followed by the addition of Dess-Martin periodinane $(0.70 \mathrm{mmol}, 0.30 \mathrm{~g})$. The solution was left to stir for $20 \mathrm{~h}$ while allowing it to warm up to r.t., and then the reaction was quenched by the addition of saturated aqueous $\mathrm{NaHCO}_{3}(5 \mathrm{~mL})$. The mixture was transferred to a separatory funnel where the aqueous layer was extracted with DCM $(2 x)$, and the combined organic layers were washed with saturated aqueous $\mathrm{NaHCO}_{3}(1 \mathrm{x})$ and brine $(1 \mathrm{x})$, dried over $\mathrm{Na}_{2} \mathrm{SO}_{4}$, filtered and concentrated. The crude product was purified by column chromatography over silica gel (MeOH in DCM $0 \%$ to $25 \% \mathrm{v} / \mathrm{v})$ to yield epoxyketone $33\left(0.20 \mathrm{mmol}, 0.062 \mathrm{~g}, 85 \%\right.$ over 2 steps). ${ }^{1} \mathrm{H} \mathrm{NMR}\left(400 \mathrm{MHz}, \mathrm{CDCl}_{3}\right) \delta 4.83(\mathrm{~d}, J=8.6 \mathrm{~Hz}$, $1 \mathrm{H}), 4.45-4.27(\mathrm{~m}, 1 \mathrm{H}), 3.29(\mathrm{~d}, J=4.9 \mathrm{~Hz}, 1 \mathrm{H}), 2.89(\mathrm{~d}, J=5.0 \mathrm{~Hz}, 1 \mathrm{H}), 1.87(\mathrm{~d}, J=12.5 \mathrm{~Hz}, 1 \mathrm{H}), 1.77-1.63(\mathrm{~m}, 4 \mathrm{H}), 1.61-1.58$ $(\mathrm{m}, 1 \mathrm{H}), 1.52(\mathrm{~s}, 3 \mathrm{H}), 1.45-1.39(\mathrm{~m}, 1 \mathrm{HH}), 1.23-1.10(\mathrm{~m}, 4 \mathrm{H}), 0.99-0.91(\mathrm{~m}, 2 \mathrm{H}) .{ }^{13} \mathrm{C} \mathrm{NMR}\left(101 \mathrm{MHz}, \mathrm{CDCl}_{3}\right) \delta 214.08,155.78$, $79.91,59.17,52.53,50.93,39.00,34.41,34.24,32.07,28.45,26.53,26.40,26.08,16.95$. LC-MS (linear gradient $10 \rightarrow 90 \% \mathrm{MeCN}$, $0.1 \%$ TFA, $15 \mathrm{~min})$ : Rt (min): 9.56 (ESI-MS (m/z): $312.43\left(\mathrm{M}+\mathrm{H}^{+}\right)$). HRMS: calculated for $\mathrm{C}_{17} \mathrm{H}_{29} \mathrm{NO}_{4} 312.20966$ [M+H] $]^{+}$found 312.21002 .

$\mathbf{H}_{2} \mathrm{~N}$-Cha-EK (34). To a solution of $33(7.44 \mathrm{mmol}, 2.32 \mathrm{~g})$ in DCM $(10 \mathrm{~mL})$ was added trifluoroacetic acid $(5 \mathrm{~mL})$, and the reaction<smiles>N[C@@H](CC1CCCCC1)C(=O)OC1CO1</smiles>
mixture was stirred under argon for 1 hour at r.t.. The mixture was then concentrated and co-evaporated with toluene $(3 \mathrm{x})$, followed by purification of the crude product using column chromatography over silica gel $(\mathrm{MeOH}$ in $\mathrm{DCM}-2 \%$ to $10 \% \mathrm{v} / \mathrm{v})$ to obtain the TFA salt of epoxyketone $34(4.15 \mathrm{mmol}, 1.35 \mathrm{~g}, 56 \%) .{ }^{1} \mathrm{H} \mathrm{NMR}(400 \mathrm{MHz}$, $\left.\mathrm{CDCl}_{3}\right) \delta 4.27-3.95(\mathrm{~m}, 1 \mathrm{H}), 3.15(\mathrm{~d}, J=4.5 \mathrm{~Hz}, 1 \mathrm{H}), 2.92(\mathrm{~d}, J=4.5 \mathrm{~Hz}, 1 \mathrm{H}), 1.83(\mathrm{~d}, J=12.5 \mathrm{~Hz}, 1 \mathrm{H}), 1.73-$ $1.61(\mathrm{~m}, 5 \mathrm{H}), 1.54(\mathrm{~s}, 3 \mathrm{H}), 1.52-1.46(\mathrm{~m}, 1 \mathrm{H}), 1.33-1.07(\mathrm{~m}, 4 \mathrm{H}), 1.03-0.85(\mathrm{~m}, 2 \mathrm{H}) .{ }^{13} \mathrm{C} \mathrm{NMR}(101 \mathrm{MHz}$ $\left.\mathrm{CDCl}_{3}\right) \delta 205.73,58.94,52.64,51.67,37.85,33.90,33.44,31.75,26.32,25.98,25.57,16.82$. LC-MS (linear gradient $10 \rightarrow 90 \%$ MeCN, 0.1\% TFA, $15 \mathrm{~min})$ : Rt (min): 6.54 (ESI-MS (m/z): $\left.212.43\left(\mathrm{M}+\mathrm{H}^{+}\right)\right)$. HRMS: calculated for $\mathrm{C}_{12} \mathrm{H}_{21} \mathrm{NO}_{2} 212.15723[\mathrm{M}+\mathrm{H}]^{+} ;$found 212.15865 . 
D) Synthesis of LU-035i
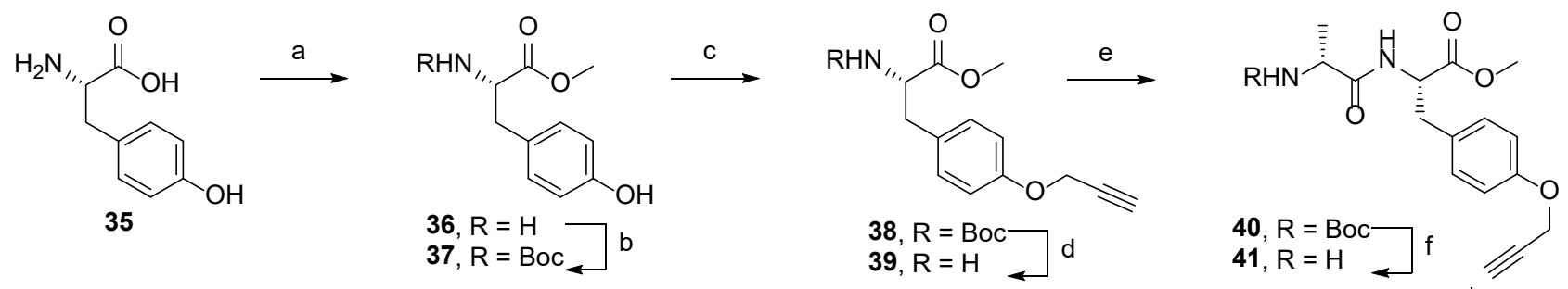

$$
\begin{aligned}
& 38, \mathrm{R}=\mathrm{Boc} \longrightarrow \mathrm{d} \\
& 39, \mathrm{R}=\mathrm{H}
\end{aligned}
$$

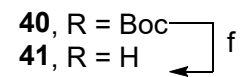<smiles>C1CCCC1</smiles>

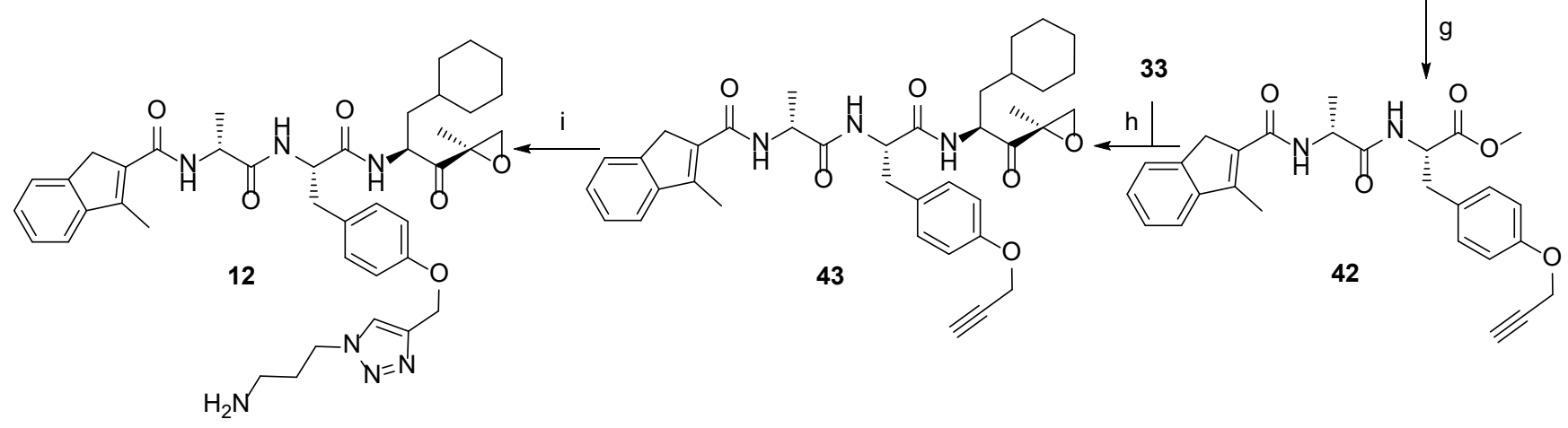

Scheme S4. Synthesis of functionalized immunoproteasome inhibitor 14. Reagents and conditions: a) $\mathrm{SOCl}_{2}, \mathrm{MeOH}$ quant.; b) $\mathrm{Boc}_{2} \mathrm{O}$, sat. aq. $\mathrm{NaHCO}_{3}$, dioxane, 93\%; c) Propargyl bromide, $\mathrm{K}_{2} \mathrm{CO}_{3}, \mathrm{DMF}, 96 \%$. d) TFA, DCM, 98\%; e) Boc-D-Ala, HCTU, DIPEA, DCM, quant.; f) TFA, DCM, quant.; g) 3-Methylindene-2-carboxylic acid, HCTU, DIPEA, DCM, 66\%. h) i. $\mathrm{N}_{2} \mathrm{H}_{4} \cdot \mathrm{H}_{2} \mathrm{O}, \mathrm{MeOH}, 16 \mathrm{~h}$; ii. tBuONO, $4 \mathrm{M} \mathrm{HCl}$ in dioxane, DMF, $-30^{\circ} \mathrm{C}$; iii. 33, DIPEA, DMF, 83\%.; i) 3-azidopropan-1-amine, $\mathrm{CuSO}_{4}, \mathrm{NaAsc}^{\mathrm{D}} \mathrm{DMF}, 2 \mathrm{~h}, 54 \%$

$\mathrm{H}_{2} \mathrm{~N}$-Tyr-OMe (36). L-tyrosine $35(25 \mathrm{mmol}, 4.5 \mathrm{~g})$ was dissolved in dry methanol $(42 \mathrm{~mL})$ and the solution was cooled to $0{ }^{\circ} \mathrm{C}$ in an<smiles>COC(=O)[C@H](N)Cc1ccc(O)cc1</smiles>
ice bath. Thionyl chloride $(42 \mathrm{mmol}, 3.8 \mathrm{~mL})$ was added dropwise, after which the reaction mixture was stirred for $18 \mathrm{~h}$ at r.t. under an argon atmosphere. Removal of the solvent under reduced pressure then afforded the colorless product methyl L-tyrosinate hydrochloride 36 (25 mmol, $5.9 \mathrm{~g}$, quant.). ${ }^{1} \mathrm{H}$ NMR (400 MHz, Methanol$\left.d_{4}\right) \delta 7.10-7.02(\mathrm{~m}, 2 \mathrm{H}), 6.83-6.73(\mathrm{~m}, 2 \mathrm{H}), 4.24(\mathrm{dd}, J=7.5,5.9 \mathrm{~Hz}, 1 \mathrm{H}), 3.81(\mathrm{~s}, 3 \mathrm{H}), 3.17(\mathrm{dd}, J=14.5$, $5.9 \mathrm{~Hz}, 1 \mathrm{H}), 3.06$ (dd, $J=14.5,7.5 \mathrm{~Hz}, 1 \mathrm{H}) .{ }^{13} \mathrm{C}$ NMR (101 MHz, MeOD) $\delta 170.56,158.42,131.49,125.54$, 116.90, 55.39, 53.56, 36.65. LC-MS (linear gradient $10 \rightarrow 90 \% \mathrm{MeCN}, 0.1 \%$ TFA, $15 \mathrm{~min}):$ Rt $(\mathrm{min}): 6.45$ (ESI-MS (m/z): 196.02 $\left(\mathrm{M}+\mathrm{H}^{+}\right)$). HRMS: calculated for $\mathrm{C}_{10} \mathrm{H}_{13} \mathrm{NO}_{3} 196.08954[\mathrm{M}+\mathrm{H}]^{+}$; found 196.08910 .

Boc-Tyr-OMe (37). To a mixture of $36(25 \mathrm{mmol}, 5.9 \mathrm{~g})$ in saturated aqueous $\mathrm{NaHCO}_{3}(65 \mathrm{~mL})$ was added dropwise a solution of diBocHN, tert-butyl dicarbonate $(34 \mathrm{mmol}, 7.4 \mathrm{~g})$ in 1,4-dioxane $(65 \mathrm{~mL})$, and the reaction mixture was stirred for $20 \mathrm{~h}$ at r.t.. The mixture was then concentrated until approximately $10 \mathrm{~mL}$ of aqueous solution remained and this was extracted with EtOAc $(3 \times 10 \mathrm{~mL})$. The combined organic layers were dried over $\mathrm{Na}_{2} \mathrm{SO}_{4}$, filtered and concentrated, and the crude was purified by chromatography on silica gel ( $\mathrm{MeOH}$ in $\mathrm{DCM}-0 \%$ to $10 \% \mathrm{v} / \mathrm{v})$ to give methyl (tert-butoxycarbonyl)-L-tyrosinate $37(23.3 \mathrm{mmol}, 6.87 \mathrm{~g}, 93 \%) .{ }^{1} \mathrm{H} \mathrm{NMR}\left(400 \mathrm{MHz}, \mathrm{CDCl}_{3}\right) \delta$ $6.97(\mathrm{~d}, J=8.3 \mathrm{~Hz}, 2 \mathrm{H}), 6.73(\mathrm{~d}, J=8.1 \mathrm{~Hz}, 2 \mathrm{H}), 5.00(\mathrm{~d}, J=8.1 \mathrm{~Hz}, 1 \mathrm{H}), 4.54(\mathrm{q}, J=6.0 \mathrm{~Hz}, 1 \mathrm{H}), 3.72(\mathrm{~s}, 3 \mathrm{H}), 3.04(\mathrm{dd}, J=13.9$, $5.7 \mathrm{~Hz}, 1 \mathrm{H}$ ), 2.97 (dd, $J=14.1,6.1 \mathrm{~Hz}, 1 \mathrm{H}), 1.42(\mathrm{~s}, 9 \mathrm{H}) .{ }^{13} \mathrm{C} \mathrm{NMR}\left(101 \mathrm{MHz}, \mathrm{CDCl}_{3}\right) \delta$ 165.14, 155.24, 130.40, 115.46, 54.42, 52.27, 37.59, 28.42. LC-MS (linear gradient $10 \rightarrow 90 \% \mathrm{MeCN}, 0.1 \%$ TFA, $15 \mathrm{~min}):$ Rt $(\mathrm{min}): 9.13\left(\mathrm{ESI}-\mathrm{MS}(\mathrm{m} / \mathrm{z}): 296.32\left(\mathrm{M}+\mathrm{H}^{+}\right)\right.$). HRMS: calculated for $\mathrm{C}_{15} \mathrm{H}_{21} \mathrm{NO}_{5} 296.14197[\mathrm{M}+\mathrm{H}]^{+}$; found 296.14288 . 
Boc-Tyr(Alkyne)-OMe (38). A mixture of methyl (tert-butoxycarbonyl)-L-tyrosinate 37 (0.50 mmol, $0.15 \mathrm{~g})$, propargyl bromide (0.55 BochN, $\mathrm{mmol}, 0.065 \mathrm{~g})$ and $\mathrm{K}_{2} \mathrm{CO}_{3}(1.00 \mathrm{mmol}, 0.139 \mathrm{~g})$ in DMF $(0.8 \mathrm{~mL})$ was stirred for $20 \mathrm{~h}$ at r.t. The reaction mixture was then diluted with $\mathrm{EtOAc}$, and the organic layer was washed with $1 \mathrm{M} \mathrm{HCl}(2 \mathrm{x})$, $\mathrm{H}_{2} \mathrm{O}(2 \mathrm{x})$ and brine (2x). The organic phase was then dried over $\mathrm{MgSO}_{4}$, filtered and concentrated to yield $38(0.48 \mathrm{mmol}, 0.16 \mathrm{~g}, 96 \%)$. ${ }^{1} \mathrm{H}$ NMR $\left(400 \mathrm{MHz}, \mathrm{CDCl}_{3}\right) \delta 7.06(\mathrm{~d}, J=8.5 \mathrm{~Hz}, 2 \mathrm{H}), 6.91(\mathrm{~d}, J=$ $8.6 \mathrm{~Hz}, 2 \mathrm{H}), 4.96(\mathrm{~d}, J=7.6 \mathrm{~Hz}, 1 \mathrm{H}), 4.67(\mathrm{~d}, J=2.4 \mathrm{~Hz}, 2 \mathrm{H}), 4.55(\mathrm{q}, J=6.0 \mathrm{~Hz}, 1 \mathrm{H}), 3.71(\mathrm{~s}, 3 \mathrm{H})$, 3.06 (dd, $J=13.9,5.7 \mathrm{~Hz}, 1 \mathrm{H}$ ), 3.00 (dd, $J=14.0,6.1 \mathrm{~Hz}, 1 \mathrm{H}), 2.52(\mathrm{t}, J=2.4 \mathrm{~Hz}, 1 \mathrm{H}), 1.42(\mathrm{~s}, 9 \mathrm{H})$.

${ }^{13} \mathrm{C}$ NMR $\left(101 \mathrm{MHz}, \mathrm{CDCl}_{3}\right) \delta 130.47,115.10,75.64,55.96,54.62,52.37,37.64,28.46$. LC-MS (linear gradient $10 \rightarrow 90 \% \mathrm{MeCN}$, 0.1\% TFA, $15 \mathrm{~min})$ : Rt (min): 10.35 (ESI-MS (m/z): $334.55\left(\mathrm{M}+\mathrm{H}^{+}\right)$). HRMS: calculated for $\mathrm{C}_{18} \mathrm{H}_{23} \mathrm{NO}_{5} 334.15762[\mathrm{M}+\mathrm{H}]^{+}$; found 334.15699 .

$\mathbf{H}_{2} \mathbf{N}-\mathbf{T y r}($ Alkyne)-OMe (39). Trifluoroacetic acid $(3.9 \mathrm{mmol}, 0.30 \mathrm{~mL})$ was added dropwise to a solution of $38(0.47 \mathrm{mmol}, 0.16 \mathrm{~g})$ in<smiles>C#CCOc1ccc(C[C@H](N)C(=O)OC)cc1</smiles>
DCM $(0.6 \mathrm{~mL})$. The mixture was stirred at r.t. and monitored by TLC until the protected amine was consumed. After 1 hour the solvents were removed in vacuo. The residue was co-evaporated with toluene (2x) and $\mathrm{CHCl}_{3}(2 \mathrm{x})$ to afford the methyl 39 as TFA salt $(0.46 \mathrm{mmol}, 0.16 \mathrm{~g}, 98 \%) .{ }^{1} \mathrm{H}$ NMR $(400$ $\mathrm{MHz}$, Methanol- $\left.d_{4}\right) \delta 7.18(\mathrm{~d}, J=8.7 \mathrm{~Hz}, 2 \mathrm{H}), 7.00(\mathrm{~d}, J=8.6 \mathrm{~Hz}, 2 \mathrm{H}), 4.73(\mathrm{~d}, J=2.4 \mathrm{~Hz}, 2 \mathrm{H}), 4.27$ (dd, $J=7.4,6.0 \mathrm{~Hz}, 1 \mathrm{H}), 3.81(\mathrm{~s}, 3 \mathrm{H}), 3.21(\mathrm{dd}, J=14.5,5.9 \mathrm{~Hz}, 1 \mathrm{H}), 3.11(\mathrm{dd}, J=14.5,7.5 \mathrm{~Hz}, 1 \mathrm{H}), 2.95(\mathrm{t}$, $J=2.3 \mathrm{~Hz}, 1 \mathrm{H}) .{ }^{13} \mathrm{C}$ NMR $(101 \mathrm{MHz}, \mathrm{MeOD}) \delta 170.51,158.89,131.50,127.83,116.60,76.83,56.60,55.28,53.58,36.61$. LC-MS (linear gradient $10 \rightarrow 90 \% \mathrm{MeCN}, 0.1 \%$ TFA, $15 \mathrm{~min}$ ): Rt $(\mathrm{min}): 7.22$ (ESI-MS (m/z): $234.67 .55\left(\mathrm{M}+\mathrm{H}^{+}\right)$). HRMS: calculated for $\mathrm{C}_{13} \mathrm{H}_{15} \mathrm{NO}_{3} 234.10519[\mathrm{M}+\mathrm{H}]^{+}$; found 234.10677.

Boc-Ala-Tyr(Alkyne)-OMe (40). To a mixture of Boc-D-Ala (17.9 mmol, $3.38 \mathrm{~g})$ in dry DCM (150 mL) were added HCTU (17.9 mmol,<smiles>C#CCOc1ccc(C[C@H](NC(=O)[C@H](C)NC(=O)c2ccccc2)C(=O)OC)cc1</smiles>
$7.39 \mathrm{~g})$ and DiPEA $(53.1 \mathrm{mmol}, 9.25 \mathrm{~mL})$. After waiting for all of the HCTU to dissolve, 39 (10.0 $\mathrm{mmol}, 3.47 \mathrm{~g}$ ) was added to the reaction mixture that was consequently left to stir for $22 \mathrm{~h}$ at r.t.. The solvents were evaporated under reduced pressure and the residue was dissolved in EtOAc. The organic phase was washed with $1 \mathrm{M} \mathrm{HCl}(2 \mathrm{x})$, saturated aqueous $\mathrm{NaHCO}_{3}(2 \mathrm{x})$ and brine $(2 \mathrm{x})$, then dried over $\mathrm{MgSO}_{4}$, filtered and concentrated. Finally, the crude was purified by flash column chromatography over silica gel ( $\mathrm{MeOH}$ in $\mathrm{DCM}-0 \%$ to $2 \% \mathrm{v} / \mathrm{v})$ to provide $40(10.0 \mathrm{mmol}, 4.10 \mathrm{~g}$, quant.). ${ }^{1} \mathrm{H}$ NMR $\left(400 \mathrm{MHz}, \mathrm{CDCl}_{3}\right) \delta 7.04(\mathrm{~d}, J=8.6 \mathrm{~Hz}, 2 \mathrm{H}), 6.89(\mathrm{~d}, J=8.6 \mathrm{~Hz}, 2 \mathrm{H}), 6.62(\mathrm{~s}, 1 \mathrm{H})$, $4.97(\mathrm{~s}, 1 \mathrm{H}), 4.87-4.77(\mathrm{~m}, 1 \mathrm{H}), 4.66(\mathrm{~d}, J=2.4 \mathrm{~Hz}, 2 \mathrm{H}), 4.17(\mathrm{~s}, 1 \mathrm{H}), 3.71(\mathrm{~s}, 3 \mathrm{H}), 3.09(\mathrm{dd}, J=14.0,5.6 \mathrm{~Hz}, 1 \mathrm{H}), 3.03(\mathrm{dd}, J=$ $14.1,6.1 \mathrm{~Hz}, 1 \mathrm{H}), 2.51(\mathrm{t}, J=2.3 \mathrm{~Hz}, 1 \mathrm{H}), 1.44(\mathrm{~s}, 10 \mathrm{H}), 1.30(\mathrm{~d}, J=7.1 \mathrm{~Hz}, 3 \mathrm{H}) .{ }^{13} \mathrm{C} \mathrm{NMR}\left(101 \mathrm{MHz}, \mathrm{CDCl}_{3}\right) \delta 172.33,171.91$, 156.83, 130.42, 128.80, 115.12, 78.63, 77.36, 75.65, 55.92, 53.28, 52.47, 50.10, 37.18, 28.43, 18.51. LC-MS (linear gradient $10 \rightarrow$ 90\% MeCN, 0.1\% TFA, 15 min): Rt (min): 10.56 (ESI-MS (m/z): $405.78\left(\mathrm{M}+\mathrm{H}^{+}\right)$). HRMS: calculated for $\mathrm{C}_{21} \mathrm{H}_{28} \mathrm{~N}_{2} \mathrm{O}_{6} 405.194474$ $[\mathrm{M}+\mathrm{H}]^{+}$; found 405.19412 .

$\mathbf{H}_{2} \mathrm{~N}$-Ala-Tyr(Alkyne)-OMe (41). Trifluoroacetic acid $(5.3 \mathrm{~mL}$ ) was added dropwise to a solution of 40 (8.42 $\mathrm{mmol}, 3.41 \mathrm{~g})$ in<smiles>COC(=O)[C@H](Cc1ccc(O)cc1)NC(=O)[C@H](C)N</smiles>
anhydrous DCM (12 mL). The mixture was stirred under argon at r.t., and after $19 \mathrm{~h}$ the solvents were removed in vacuo. The residue was co-evaporated with toluene $(2 \mathrm{x})$ and $\mathrm{CHCl}_{3}(2 \mathrm{x})$ to give 41 as a TFA salt (8.41 mmol, $3.52 \mathrm{~g}$, quant.). ${ }^{1} \mathrm{H}$ NMR $\left(400 \mathrm{MHz}, \mathrm{CDCl}_{3}\right) \delta 8.16(\mathrm{~d}, J=8.0 \mathrm{~Hz}, 1 \mathrm{H}), 7.05$ (d, $J=$ $8.6 \mathrm{~Hz}, 2 \mathrm{H}), 6.85(\mathrm{~d}, J=8.7 \mathrm{~Hz}, 2 \mathrm{H}), 4.74-4.65(\mathrm{~m}, 1 \mathrm{H}), 4.61(\mathrm{~d}, J=2.3 \mathrm{~Hz}, 2 \mathrm{H}), 4.10$ (q, $J=6.8 \mathrm{~Hz}$, 1H), 3.62 (s, 3H), 3.09 (dd, $J=14.1,5.5 \mathrm{~Hz}, 1 \mathrm{H}$ ), 2.87 (dd, $J=14.0,8.6 \mathrm{~Hz}, 1 \mathrm{H}), 2.52$ (t, $J=2.3 \mathrm{~Hz}$, 1H), $1.26(\mathrm{~d}, J=7.0 \mathrm{~Hz}, 3 \mathrm{H}) .{ }^{13} \mathrm{C}$ NMR $\left(101 \mathrm{MHz}, \mathrm{CDCl}_{3}\right) \delta 172.7,170.3,156.7,130.4,129.1,115.1$, 78.6, 75.9, 55.8, 54.0, 52.8, 49.4, 36.7, 17.2. LC-MS (linear gradient $10 \rightarrow 90 \%$ MeCN, 0.1\% TFA, 15 $\min$ ): Rt (min): 8.12 (ESI-MS (m/z): $305.12\left(\mathrm{M}+\mathrm{H}^{+}\right)$). HRMS: calculated for $\mathrm{C}_{16} \mathrm{H}_{20} \mathrm{~N}_{2} \mathrm{O}_{4} 305.14231$ [M+H] $]^{+}$found 305.14341 . 
3MelndAc-Ala-Tyr(Alkyne)-OMe (42). To a mixture of 3-methyl-1H-indene-2-carboxylic acid (6.61 mmol, $1.15 \mathrm{~g})$ in dry DCM (55 mL)

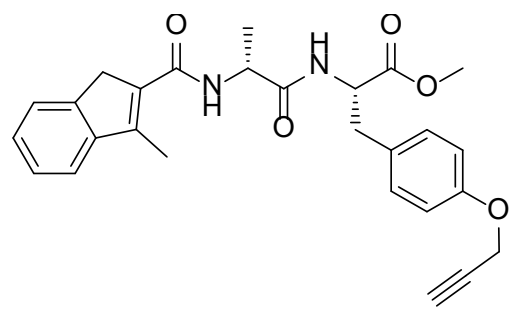
were added HCTU (6.61 mmol, $2.73 \mathrm{~g})$ and DiPEA (19.2 mmol, $3.35 \mathrm{~mL})$. After waiting for all of the HCTU to dissolve, $41(4.00 \mathrm{mmol}, 1.68 \mathrm{~g})$ was added to the reaction mixture that was consequently left to stir overnight under argon at r.t.. The solvents were evaporated under reduced pressure and the residue was dissolved in EtOAc. The organic phase was washed with $1 \mathrm{M} \mathrm{HCl}(2 \mathrm{x})$, saturated aqueous $\mathrm{NaHCO}_{3}(2 \mathrm{x})$ and brine $(2 \mathrm{x})$, then dried over $\mathrm{MgSO}_{4}$, filtered and concentrated. Finally, the crude was purified by flash column chromatography over silica gel $(\mathrm{MeOH}$ in $\mathrm{DCM}-0 \%$ to $5 \% \mathrm{v} / \mathrm{v})$ to provide $42(2.65 \mathrm{mmol}$, $1.22 \mathrm{~g}, 66 \%) .{ }^{1} \mathrm{H}$ NMR $\left(400 \mathrm{MHz}, \mathrm{CDCl}_{3}\right) \delta 7.48-7.30(\mathrm{~m}, 4 \mathrm{H}), 7.05(\mathrm{~d}, J=8.7 \mathrm{~Hz}, 2 \mathrm{H}), 6.84(\mathrm{~d}, J=8.7 \mathrm{~Hz}, 2 \mathrm{H}), 6.42(\mathrm{~d}, J=7.2 \mathrm{~Hz}$, $1 \mathrm{H}), 4.91-4.78(\mathrm{~m}, 1 \mathrm{H}), 4.68(\mathrm{p}, J=7.0 \mathrm{~Hz}, 1 \mathrm{H}), 4.54(\mathrm{~d}, J=2.4 \mathrm{~Hz}, 2 \mathrm{H}), 3.71(\mathrm{~s}, 3 \mathrm{H}), 3.63-3.53(\mathrm{~m}, 2 \mathrm{H}), 3.13(\mathrm{dd}, J=14.0,5.5$ $\mathrm{Hz}, 1 \mathrm{H}), 3.04(\mathrm{dd}, J=14.0,6.5 \mathrm{~Hz}, 1 \mathrm{H}), 2.53(\mathrm{t}, J=2.2 \mathrm{~Hz}, 3 \mathrm{H}), 2.47(\mathrm{t}, J=2.4 \mathrm{~Hz}, 1 \mathrm{H}), 1.39(\mathrm{~d}, J=7.0 \mathrm{~Hz}, 3 \mathrm{H}) .{ }^{13} \mathrm{C} \mathrm{NMR}(101 \mathrm{MHz}$, $\left.\mathrm{CDCl}_{3}\right) \delta 172.3,171.9,165.9,156.8,148.1,145.6,142.2,131.7,130.4,128.8,127.5,126.9,124.0,120.4,115.1,77.4,75.6,55.8$, 53.3, 52.5, 48.7, 38.4, 37.1, 18.8, 12.4. LC-MS (linear gradient $10 \rightarrow 90 \% \mathrm{MeCN}, 0.1 \%$ TFA, $15 \mathrm{~min}): \mathrm{Rt}(\mathrm{min}): 10.21$ (ESI-MS (m/z): $\left.461.23\left(\mathrm{M}+\mathrm{H}^{+}\right)\right)$. HRMS: calculated for $\mathrm{C}_{27} \mathrm{H}_{28} \mathrm{~N}_{2} \mathrm{O}_{5} 461.19982[\mathrm{M}+\mathrm{H}]^{+}$; found 461.20031.

LU-035i-alkyne (43). Compound $42(0.109 \mathrm{mmol}, 0.050 \mathrm{~g})$ and hydrazine monohydrate $(3.25 \mathrm{mmol}, 158 \mu \mathrm{L})$ were dissolved in<smiles>C#CCOc1ccc(C[C@H](NC(=O)[C@H](C)NC(=O)C2=C(C)c3ccccc3C2)C(=O)N[C@@H](CC2CCCCC2)C(=O)[C@@]2(C)CO2)cc1</smiles>
methanol $(5 \mathrm{~mL})$, and the reaction mixture was stirred overnight at r.t.. Once LC-MS analysis confirmed complete conversion to the product, the mixture was concentrated and the residue was co-evaporated with toluene $(3 \mathrm{x})$ and $\mathrm{CHCl}_{3}(3 \mathrm{x})$. The obtained crude was dissolved in anhydrous DMF $(2 \mathrm{~mL})$ and the resulting mixture was cooled to $-30^{\circ} \mathrm{C}$. Tert-butyl nitrite $(0.24 \mathrm{mmol}, 28.6 \mu \mathrm{L})$ and $4.0 \mathrm{M} \mathrm{HCl}$ in dioxane $(0.61 \mathrm{mmol}$, $152 \mu \mathrm{l})$ were added to the mixture, and the solution was stirred for $3 \mathrm{~h}$ at $-30^{\circ} \mathrm{C}$. Then a solution of epoxyketone $33(0.080 \mathrm{mmol}, 0.026 \mathrm{~g})$ in DMF $(0.2 \mathrm{~mL})$ and DiPEA (1.09 $\mathrm{mmol}, 189 \mu \mathrm{L})$ were added to the reaction mixture that was then stirred overnight while coming to r.t.. The mixture was diluted with EtOAc $(5 \mathrm{~mL})$, and the organic layer was washed with $\mathrm{H}_{2} \mathrm{O}(3 \mathrm{x})$ and brine $(1 \mathrm{x})$, dried over $\mathrm{MgSO}_{4}$, filtered and concentrated. Finally, the crude was purified using column chromatography over silica gel (MeOH in DCM $2.5 \% \mathrm{v} / \mathrm{v})$ to afford LU-035i-alkyne $43\left(0.070 \mathrm{mmol}, 43 \mathrm{mg}, 83 \%\right.$ over 2 steps). ${ }^{1} \mathrm{H}$ NMR $\left(400 \mathrm{MHz}, \mathrm{CDCl}_{3}\right) \delta 7.48-7.45(\mathrm{~m}, 2 \mathrm{H}), 7.37$ - $7.33(\mathrm{~m}, 2 \mathrm{H}), 7.15(\mathrm{~d}, J=8.6 \mathrm{~Hz}, 2 \mathrm{H}), 6.87(\mathrm{~d}, J=8.6 \mathrm{~Hz}, 2 \mathrm{H}), 6.71(\mathrm{~d}, J=7.8 \mathrm{~Hz}, 1 \mathrm{H}), 6.32(\mathrm{~d}, J=4.9 \mathrm{~Hz}, 1 \mathrm{H}), 6.31(\mathrm{~d}, J=3.8$ $\mathrm{Hz}, 1 \mathrm{H}), 4.62-4.60(\mathrm{~m}, 1 \mathrm{H}), 4.59(\mathrm{~d}, J=2.4 \mathrm{~Hz}, 2 \mathrm{H}), 4.57-4.54(\mathrm{~m}, 1 \mathrm{H}), 4.54-4.52(\mathrm{~m}, 1 \mathrm{H}), 3.61-3.59(\mathrm{~m}, 2 \mathrm{H}), 3.24(\mathrm{~d}, J=5.0$ $\mathrm{Hz}, 1 \mathrm{H}), 3.09(\mathrm{dd}, J=14.0,6.7 \mathrm{~Hz}, 1 \mathrm{H}), 3.02(\mathrm{dd}, J=11.7,5.6 \mathrm{~Hz}, 1 \mathrm{H}), 2.86(\mathrm{~d}, J=5.0 \mathrm{~Hz}, 1 \mathrm{H}), 2.52(\mathrm{t}, J=2.2 \mathrm{~Hz}, 3 \mathrm{H}), 2.49(\mathrm{t}, J=$ $2.4 \mathrm{~Hz}, 1 \mathrm{H}), 1.74(\mathrm{~d}, J=11.3 \mathrm{~Hz}, 1 \mathrm{H}), 1.61-1.52(\mathrm{~m}, 3 \mathrm{H}), 1.45(\mathrm{~s}, 3 \mathrm{H}), 1.42(\mathrm{~s}, 1 \mathrm{H}), 1.39(\mathrm{~d}, J=7.0 \mathrm{~Hz}, 3 \mathrm{H}), 1.18-1.09(\mathrm{~m}, 5 \mathrm{H})$, $0.91-0.78(\mathrm{~m}, 3 \mathrm{H}) .{ }^{13} \mathrm{C}$ NMR $\left(101 \mathrm{MHz}, \mathrm{CDCl}_{3}\right) \delta 209.5,172.4,170.7,155.4,153.3,148.6,146.0,142.2,131.3,130.6,129.3,127.6$, 127.0, 124.0, 121.0, 115.2, 75.6, 55.9, 54.3, 52.5, 50.5, 49.8, 49.2, 38.6, 38.3, 36.9, 34.4, 34.0, 32.0, 26.4, 26.3, 26.0, 18.3, 16.8, 12.5. LC-MS (linear gradient $10 \rightarrow 90 \% \mathrm{MeCN}, 0.1 \%$ TFA, $15 \mathrm{~min}): \mathrm{Rt}(\mathrm{min}): 9.23$ (ESI-MS (m/z): $640.12\left(\mathrm{M}+\mathrm{H}^{+}\right)$). HRMS: calculated for $\mathrm{C}_{38} \mathrm{H}_{45} \mathrm{~N}_{3} \mathrm{O}_{6} 640.33084[\mathrm{M}+\mathrm{H}]^{+}$; found 640.33189 .

LU-035i-amine (12). To a solution of $43(0.45 \mathrm{mmol}, 0.29 \mathrm{~g})$ in dry DMF $(5 \mathrm{~mL}), \mathrm{CuSO}_{4}(0.11 \mathrm{mmol}, 0.028 \mathrm{~g})$ and sodium ascorbate<smiles>CC1=C(C(=O)N[C@@H](C)C(=O)N[C@@H](Cc2ccc(OCc3cn(CCCN)nn3)cc2)C(=O)N[C@@H](CC2CCCCC2)C(=O)[C@@]2(C)CO2)Cc2ccccc21</smiles>
$(0.22 \mathrm{mmol}, 0.045 \mathrm{~g})$ were added. 3-azidopropan-1-amine $(0.9 \mathrm{mmol}, 0.09 \mathrm{~g})$ was added and stirred for $2 \mathrm{~h}$ at r.t.. After concentration, the crude was purified using column chromatography over silica gel (MeOH in DCM $-0 \%$ to $20 \% \mathrm{v} / \mathrm{v}$ ) to afford LU035i-amine 12 (0.33 mmol, $0.25 \mathrm{mg}, 54 \%)$. ${ }^{1} \mathrm{H}$ NMR (400 MHz, MeOD) $\delta 8.15(\mathrm{~s}, 1 \mathrm{H})$, 8.01 (s, 1H), 7.60 (t, $J=6.4 \mathrm{~Hz}, 3 \mathrm{H}), 7.42$ (q, $J=6.8 \mathrm{~Hz}, 4 \mathrm{H}), 7.22$ (d, J = 8.3 Hz, 3H), $6.90(\mathrm{t}, J=8.5 \mathrm{~Hz}, 4 \mathrm{H}), 5.08(\mathrm{~d}, J=6.0 \mathrm{~Hz}, 1 \mathrm{H}), 4.78-4.61(\mathrm{~m}, 5 \mathrm{H}), 4.55(\mathrm{~d}, J=7.2$ $\mathrm{Hz}, 1 \mathrm{H}), 3.79-3.71(\mathrm{~m}, 2 \mathrm{H}), 3.33(\mathrm{~d}, J=5.1 \mathrm{~Hz}, 1 \mathrm{H}), 3.23(\mathrm{dd}, J=14.0,4.9 \mathrm{~Hz}, 1 \mathrm{H})$, $3.02(\mathrm{~d}, J=5.1 \mathrm{~Hz}, 1 \mathrm{H}), 2.98-2.89(\mathrm{~m}, 1 \mathrm{H}), 2.58(\mathrm{~d}, J=2.4 \mathrm{~Hz}, 3 \mathrm{H}), 2.37(\mathrm{~s}, 4 \mathrm{H})$, $1.90(\mathrm{~d}, J=12.6 \mathrm{~Hz}, 1 \mathrm{H}), 1.84-1.61(\mathrm{~m}, 9 \mathrm{H}), 1.53(\mathrm{~d}, J=11.6 \mathrm{~Hz}, 7 \mathrm{H}), 1.34$ (dd, $J=$ 39.4, 8.8 Hz, 5H), 1.05 (q, J = 14.0, $12.4 \mathrm{~Hz}, 6 \mathrm{H}) .{ }^{13} \mathrm{C}$ NMR (101 MHz, MeOD) $\delta 175.2$, 
173.5, 158.6, 148.8, 146.7, 143.9, 133.2, 131.6, 130.8, 128.4, 127.8, 124.9, 121.8, 115.7, 62.2, 60.1, 55.3, 51.2, 50.9, 39.2, 38.6, 37.8, 35.6, 35.1, 33.0, 27.5, 27.3, 27.1, 17.9, 17.0, 12.6. LC-MS (linear gradient $10 \rightarrow 90 \% \mathrm{MeCN}, 0.1 \% \mathrm{TFA}, 15 \mathrm{~min}): \mathrm{Rt}(\mathrm{min}): 7.89$ (ESI-MS (m/z): $740.78\left(\mathrm{M}+\mathrm{H}^{+}\right)$). HRMS: calculated for $\mathrm{C}_{41} \mathrm{H}_{53} \mathrm{~N}_{7} \mathrm{O}_{6} 740.40573[\mathrm{M}+\mathrm{H}]^{+}$; found 740.40667

E) Synthesis of conjugates 1 and 2

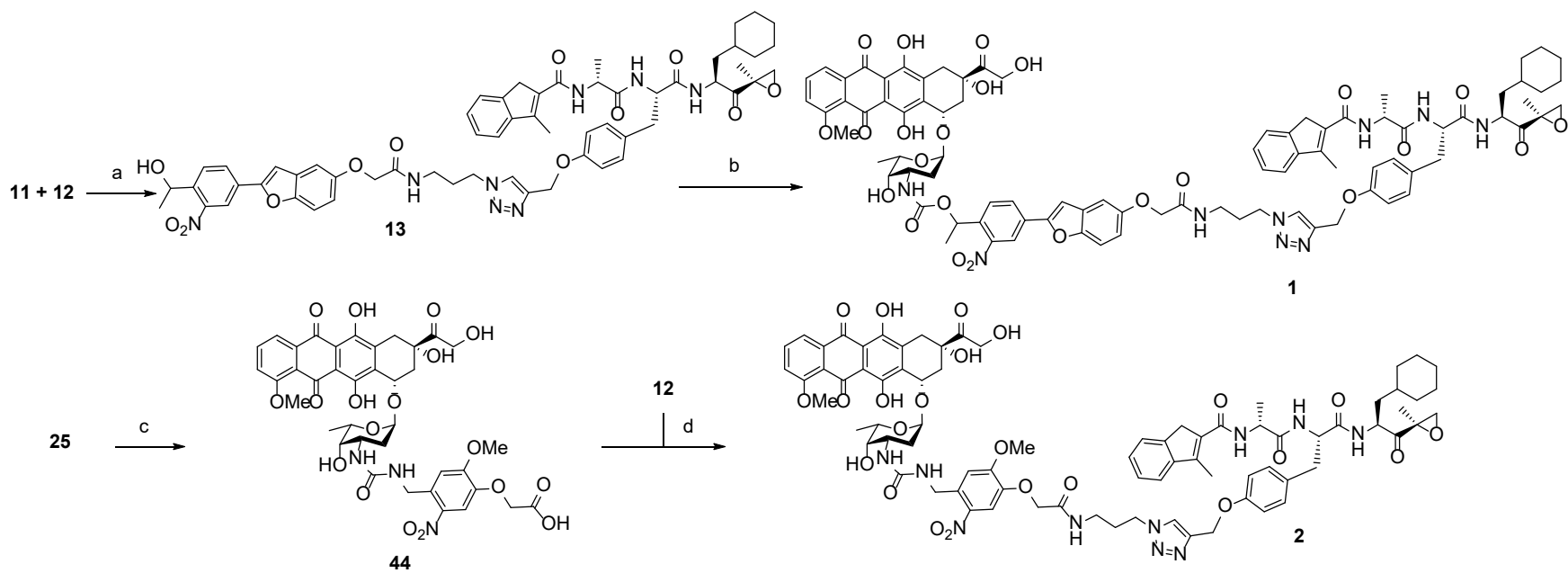

Scheme S5. Synthesis of conjugates 1 and 2. Reagents and conditions: a) HCTU, DiPEA, DCM, rt, 16h, quant; b) i. N-succinimidyl carbonate, $\mathrm{Et}_{3} \mathrm{~N}, \mathrm{DMF}$; ii. doxorubicin, DMF, r.t., protected from UV, 16h, 59\%; c) Doxorubicin, $\mathrm{Et}_{3} \mathrm{~N}, \mathrm{NMP}, 16 \mathrm{~h}, 40 \%$; d) 12 , HCTU, DiPEA, DMF, protected from UV, $0{ }^{\circ} \mathrm{C}-$ r.t., $18 \mathrm{~h}, 54 \%$.

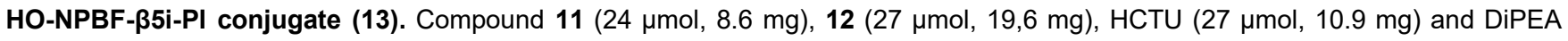

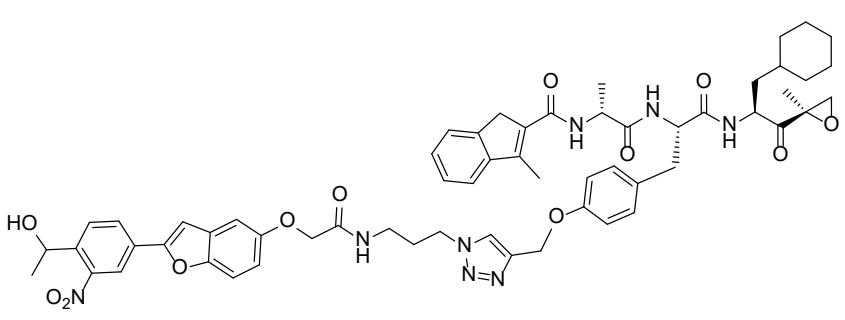
$(106 \mu \mathrm{mol}, 20 \mu \mathrm{L})$ were dissolved in DCM $(0.5 \mathrm{~mL})$ in a from light covered Eppendorf tube. After shaking the tube for $16 \mathrm{~h}$, the solvent was evaporated. The crude was purified using column chromatography over silica gel ( $\mathrm{MeOH}$ in $\mathrm{DCM}-0 \%$ to $4 \% \mathrm{v} / \mathrm{v})$ to provide 13 (24 $\mu \mathrm{mol}, 0.026 \mathrm{~g}$, quant.). ${ }^{1} \mathrm{H} \mathrm{NMR}\left(500 \mathrm{MHz}, \mathrm{CDCl}_{3}\right)$ $\delta 8.33(\mathrm{~d}, J=2.0 \mathrm{~Hz}, 1 \mathrm{H}), 8.01(\mathrm{~s}, 3 \mathrm{H}), 7.99(\mathrm{~d}, J=8.3 \mathrm{~Hz}, 1 \mathrm{H})$, $7.79(\mathrm{~d}, J=8.6 \mathrm{~Hz}, 1 \mathrm{H}), 7.65(\mathrm{~s}, 1 \mathrm{H}), 7.43(\mathrm{~d}, J=6.8 \mathrm{~Hz}, 3 \mathrm{H})$, $7.37-7.27(\mathrm{~m}, 2 \mathrm{H}), 7.13-7.03(\mathrm{~m}, 4 \mathrm{H}), 7.03(\mathrm{~d}, J=2.6 \mathrm{~Hz}, 1 \mathrm{H}), 6.99(\mathrm{dd}, J=8.9,2.6 \mathrm{~Hz}, 1 \mathrm{H}), 6.93(\mathrm{~s}, 2 \mathrm{H}), 6.78-6.73(\mathrm{~m}, 2 \mathrm{H})$, $6.71(\mathrm{~s}, 1 \mathrm{H}), 6.49(\mathrm{~s}, 1 \mathrm{H}), 5.55(\mathrm{q}, J=6.3 \mathrm{~Hz}, 1 \mathrm{H}), 5.30(\mathrm{~s}, 5 \mathrm{H}), 4.94(\mathrm{~s}, 2 \mathrm{H}), 4.60-4.47(\mathrm{~m}, 1 \mathrm{H}), 4.47(\mathrm{~s}, 2 \mathrm{H}), 4.42(\mathrm{~s}, 2 \mathrm{H}), 3.70(\mathrm{pd}$, $J=6.6,3.9 \mathrm{~Hz}, 2 \mathrm{H}), 3.57(\mathrm{~d}, J=9.6 \mathrm{~Hz}, 2 \mathrm{H}), 3.43(\mathrm{~s}, 2 \mathrm{H}), 3.25(\mathrm{~d}, J=5.0 \mathrm{~Hz}, 1 \mathrm{H}), 3.16$ (qd, $J=7.4,4.4 \mathrm{~Hz}, 2 \mathrm{H}), 3.04(\mathrm{dt}, J=14.3$, $4.3 \mathrm{~Hz}, 1 \mathrm{H}), 2.96(\mathrm{~s}, 6 \mathrm{H}), 2.88(\mathrm{~s}, 6 \mathrm{H}), 2.84(\mathrm{~d}, J=5.1 \mathrm{~Hz}, 1 \mathrm{H}), 2.48(\mathrm{q}, J=2.0 \mathrm{~Hz}, 3 \mathrm{H}), 2.19(\mathrm{q}, J=7.5,6.9 \mathrm{~Hz}, 2 \mathrm{H}), 1.73(\mathrm{~d}, J=$ $13.3 \mathrm{~Hz}, 1 \mathrm{H}), 1.64-1.59(\mathrm{~m}, 3 \mathrm{H}), 1.58-1.52(\mathrm{~m}, 1 \mathrm{H}), 1.51-1.38(\mathrm{~m}, 17 \mathrm{H}), 1.38-1.31(\mathrm{~m}, 3 \mathrm{H}), 1.26(\mathrm{~s}, 5 \mathrm{H}), 1.16-1.07(\mathrm{~m}, 1 \mathrm{H})$, $0.89(\mathrm{~d}, J=24.7 \mathrm{~Hz}, 8 \mathrm{H}), 0.86(\mathrm{~s}, 3 \mathrm{H}), 0.10(\mathrm{~s}, 4 \mathrm{H}) .{ }^{13} \mathrm{C}$ NMR $\left(126 \mathrm{MHz}, \mathrm{CDCl}_{3}\right) \delta 171.06,168.98,166.22,162.75,157.28,154.73$, $153.93,151.05,146.67,145.51,143.14,142.27,135.27,131.39,130.51,129.54,127.51,126.89,125.48,123.93,123.85,120.93$, $114.99,114.93,112.43,105.18,105.02,68.04,65.71,61.91,59.16,55.47,55.45,54.50,53.55,49.91,49.28,48.32,43.45,38.29$, 36.64, 36.55, 34.37, 33.96, 32.01, 31.58, 29.94, 29.81, 26.42, 26.24, 25.98, 25.77, 24.81, 18.69, 18.28, 17.31, 16.82, $12.59,12.47$. LC-MS (linear gradient $10 \rightarrow 90 \% \mathrm{MeCN}, 0.1 \%$ TFA, $15 \mathrm{~min}): \mathrm{Rt}(\mathrm{min}): 9.18$ (ESI-MS (m/z): $1079.47\left(\mathrm{M}+\mathrm{H}^{+}\right)$). HRMS: calculated for $\mathrm{C}_{59} \mathrm{H}_{66} \mathrm{~N}_{8} \mathrm{O}_{12} 1079.48002[\mathrm{M}+\mathrm{H}]^{+}$; found 1079.48423 
Doxo-NPBF-B5i-PI conjugate (1). Compound $13(5.6 \mu \mathrm{mol}, 3 \mathrm{mg})$ and NHS-carbonate $(5.6 \mu \mathrm{mol}, 1.4 \mathrm{mg})$ were dissolved in dry

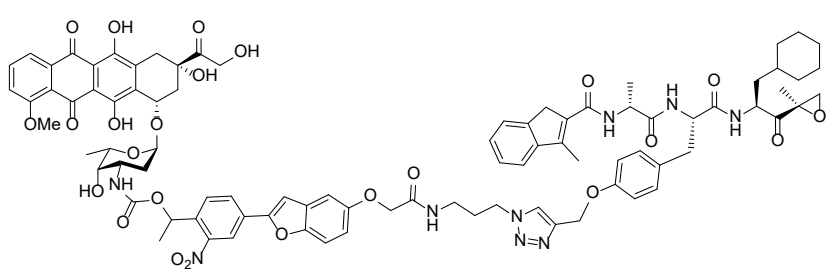
DMF $(150 \mu \mathrm{L})$ in an Eppendorf tube. $\mathrm{Et}_{3} \mathrm{~N}(16.8 \mu \mathrm{mol}, 2.3 \mu \mathrm{L})$ was then added and the mixture was shaken overnight covered from light. Doxorubicin $(5,6 \mu \mathrm{mol}, 3.04 \mathrm{mg})$ was added and the shaking was continued. The solvent was removed and the crude was purified by column chromatography $-0 \%$ to $4 \% \mathrm{v} / \mathrm{v}$ ) to give 1 as a red solid. (3.3 $\mu \mathrm{mol}, 5.4 \mathrm{mg}, 59 \%$, purity by LC-MS > 95\%). ${ }^{1} \mathrm{H}$ NMR $\left(500 \mathrm{MHz}, \mathrm{CDCl}_{3}\right) \delta 8.33(\mathrm{~d}, J=2.0 \mathrm{~Hz}, 1 \mathrm{H}), 8.00(\mathrm{~d}, J=4.5 \mathrm{~Hz}, 3 \mathrm{H}), 7.79(\mathrm{~d}, J=8.6 \mathrm{~Hz}, 1 \mathrm{H}), 7.65(\mathrm{~s}, 1 \mathrm{H}), 7.42(\mathrm{t}, J=6.6 \mathrm{~Hz}$, $3 \mathrm{H}), 7.36-7.28(\mathrm{~m}, 2 \mathrm{H}), 7.14-6.97(\mathrm{~m}, 5 \mathrm{H}), 6.93(\mathrm{~s}, 2 \mathrm{H}), 6.80-6.73(\mathrm{~m}, 2 \mathrm{H}), 6.49(\mathrm{~s}, 1 \mathrm{H}), 5.55(\mathrm{q}, J=6.3 \mathrm{~Hz}, 1 \mathrm{H}), 5.30(\mathrm{~s}, 5 \mathrm{H})$, $4.94(\mathrm{~s}, 2 \mathrm{H}), 4.63-4.49(\mathrm{~m}, 1 \mathrm{H}), 4.47(\mathrm{~s}, 2 \mathrm{H}), 4.41(\mathrm{~d}, J=6.8 \mathrm{~Hz}, 2 \mathrm{H}), 3.75-3.66(\mathrm{~m}, 2 \mathrm{H}), 3.59-3.54(\mathrm{~m}, 2 \mathrm{H}), 3.43(\mathrm{~s}, 2 \mathrm{H}), 3.25$ $(\mathrm{d}, J=5.1 \mathrm{~Hz}, 1 \mathrm{H}), 3.16$ (qd, $J=7.4,4.4 \mathrm{~Hz}, 2 \mathrm{H}), 3.09-3.01(\mathrm{~m}, 1 \mathrm{H}), 2.96(\mathrm{~s}, 7 \mathrm{H}), 2.88(\mathrm{~s}, 7 \mathrm{H}), 2.48(\mathrm{q}, J=2.0 \mathrm{~Hz}, 3 \mathrm{H}), 2.24-2.16$ $(\mathrm{m}, 2 \mathrm{H}), 1.98(\mathrm{~d}, J=24.6 \mathrm{~Hz}, 5 \mathrm{H}), 1.65-1.58(\mathrm{~m}, 3 \mathrm{H}), 1.46-1.38(\mathrm{~m}, 19 \mathrm{H}), 1.33(\mathrm{~d}, J=7.2 \mathrm{~Hz}, 3 \mathrm{H}), 1.26(\mathrm{~s}, 5 \mathrm{H}), 0.91(\mathrm{~s}, 6 \mathrm{H}), 0.89$ - $0.82(\mathrm{~m}, 5 \mathrm{H}), 0.10(\mathrm{~s}, 4 \mathrm{H}) .{ }^{13} \mathrm{C}$ NMR $(126 \mathrm{MHz}, \mathrm{CDCl} 3) \delta 171.1,169.0,166.2,162.8,157.3,154.7,153.9,151.1,146.7,145.5$, $143.1,142.3,135.3,131.4,130.5,129.5,127.5,126.9,125.5,123.9,123.9,120.9,115.0,112.4,105.2,105.0,77.4,77.2,76.9,68.0$, 65.7, 61.9, 59.3, 55.5, 54.5, 53.6, 49.9, 49.3, 48.3, 47.3, 43.6, 38.3, 36.6, 36.6, 34.4, 34.0, 32.0, 31.6, 29.9, 29.8, 26.4, 26.2, 26.0, 25.8, 24.8, 18.7, 18.3, 17.3, 16.8, 12.6, 12.5. LC-MS (linear gradient $10 \rightarrow 90 \% \mathrm{MeCN}, 0.1 \% \mathrm{TFA}, 15 \mathrm{~min}$ ): Rt (min): 9.37 (ESI-MS $\left.(\mathrm{m} / \mathrm{z}): 1648.00\left(\mathrm{M}+\mathrm{H}^{+}\right)\right)$. HRMS: calculated for $\mathrm{C}_{87} \mathrm{H}_{93} \mathrm{~N}_{9} \mathrm{O}_{24} 1648.63335[\mathrm{M}+\mathrm{H}]^{+}$; found 1648.63583

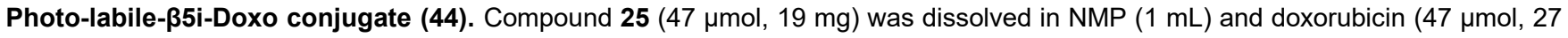

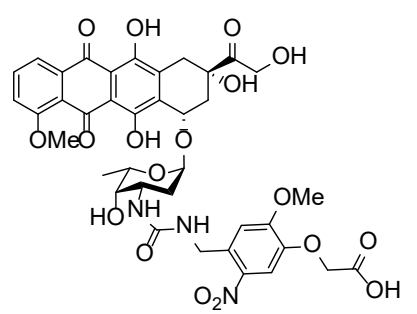
$\mathrm{mg}$ ) and TEA ( $47 \mu \mathrm{mol}, 6.5 \mu \mathrm{L})$ were added under $\mathrm{N}_{2}$. The mixture was stirred for $3 \mathrm{~d}$ at r.t., covered from light. The solvent was removed and the crude product was purified by column chromatography $(\mathrm{DCM} / \mathrm{MeOH}, 98: 2)$ to give 44 as a red-purple powder (19 $\mu \mathrm{mol}, 15 \mathrm{mg}, 40 \%)$. LC-MS (linear gradient $10 \rightarrow 90 \% \mathrm{MeCN}, 0.1 \%$ TFA, $15 \mathrm{~min}): \mathrm{Rt}(\mathrm{min}): 8.18\left(\mathrm{ESI}-\mathrm{MS}(\mathrm{m} / \mathrm{z}): 826.23\left(\mathrm{M}+\mathrm{H}^{+}\right)\right.$). HRMS: calculated for $\mathrm{C}_{38} \mathrm{H}_{39} \mathrm{~N}_{3} \mathrm{O}_{18} 826.22286[\mathrm{M}+\mathrm{H}]^{+}$; found 826.22312

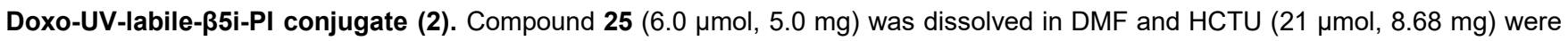

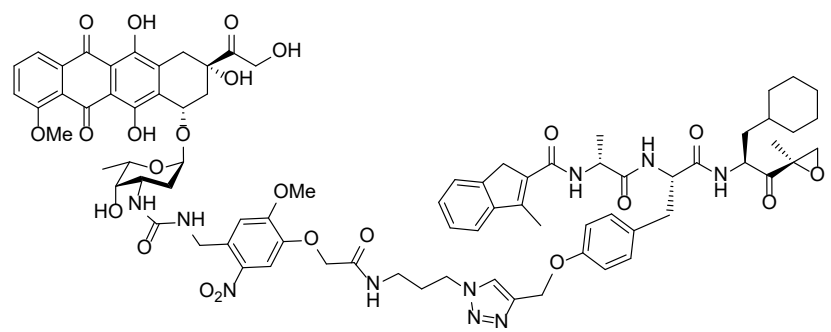
added. $44(7.0 \mu \mathrm{mol}, 4.9 \mathrm{mg})$ and DiPEA $(21 \mu \mathrm{mol}, 3.66 \mu \mathrm{L})$ were then added and the mixture was stirred overnight covered from light. The solvent was removed and the crude was purified by column chromatography (DCM:MeOH, 98:2), followed by Prep-HPLC purification, to give 2 as a red solid. $(3.2 \mu \mathrm{mol}, 4.9 \mathrm{mg}, 54 \%$, purity by LC-MS > 99\%). LC-MS (linear gradient $10 \rightarrow 90 \% \mathrm{MeCN}, 0.1 \%$ TFA, $15 \mathrm{~min})$ : Rt $(\mathrm{min}): 8.32$ (ESI-MS (m/z): $1547.87\left(\mathrm{M}+\mathrm{H}^{+}\right)$).

HRMS: calculated for $\mathrm{C}_{79} \mathrm{H}_{90} \mathrm{~N}_{10} \mathrm{O}_{23} 1547.61803[\mathrm{M}+\mathrm{H}]^{+}$; found 1547.61342

F) Synthesis of control compound NPBF-Doxo 


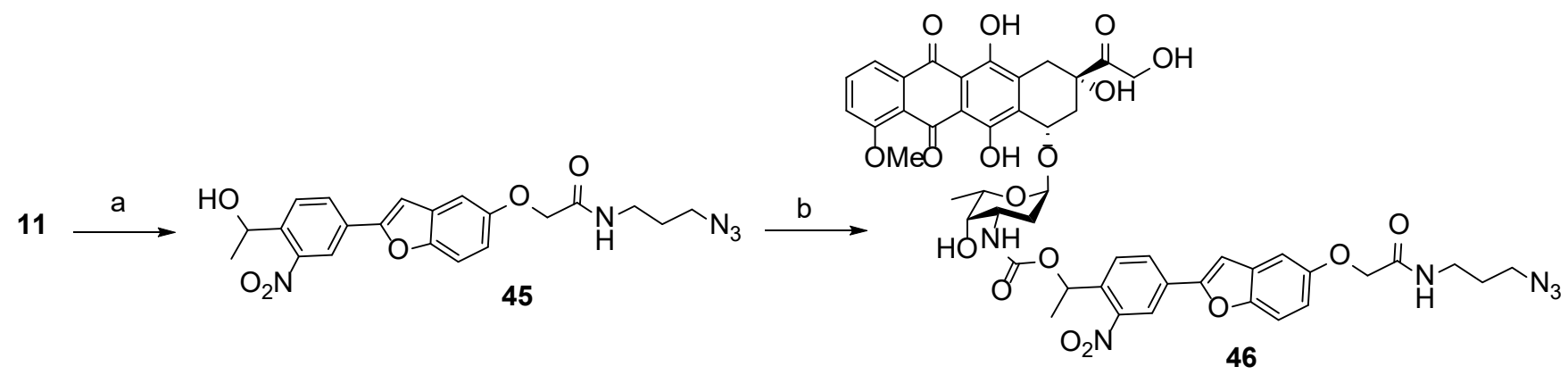

Scheme S6. Synthesis of control conjugate 46. Reagents and conditions: a) 3-azidopropan-1-amine, HCTU, DiPEA, DCM, rt, 1h, $60 \%$; b) i. $N$-succinimidyl carbonate, $\mathrm{Et}_{3} \mathrm{~N}, \mathrm{DMF} ;$ ii. doxorubicin, DMF, r.t., protected from UV, $16 \mathrm{~h}, 59 \%$

\section{$\mathrm{N}_{3}-\mathrm{NPBF}$ conjugate (45).}<smiles>N#CCCNC(=O)COc1ccc2oc(-c3ccc(C(O)O)c([N+](=O)[O-])c3)cc2c1</smiles>

Compound 11 (56 $\mu \mathrm{mol}, 20 \mathrm{mg})$, 3-azidopropan-1-amine (100 $\mu \mathrm{mol}, 10 \mu \mathrm{L})$, HCTU (100 $\mu \mathrm{mol}, 41 \mathrm{mg})$ and DiPEA $(200 \mu \mathrm{mol}, 35 \mu \mathrm{L})$ were dissolved in DMF $(1 \mathrm{~mL})$ in a from light covered Eppendorf tube. After shaking the tube for $1 \mathrm{~h}$, the solvent was evaporated. The crude was purified using column chromatography over silica gel (MeOH in $\mathrm{DCM}-0 \%$ to $1 \% \mathrm{v} / \mathrm{v}$ ) to provide $45(31 \mu \mathrm{mol}, 13.7 \mathrm{mg}, 60 \%) .{ }^{1} \mathrm{H} \mathrm{NMR}\left(400 \mathrm{MHz}, \mathrm{CDCl}_{3}\right) \delta 8.35(\mathrm{q}, \mathrm{J}=2.3,1.9 \mathrm{~Hz}, 1 \mathrm{H}), 8.03(\mathrm{dt}, \mathrm{J}=8.5,2.3 \mathrm{~Hz}$, $1 \mathrm{H}), 7.84(\mathrm{dd}, J=8.7,2.0 \mathrm{~Hz}, 1 \mathrm{H}), 7.65(\mathrm{~d}, J=2.1 \mathrm{~Hz}, 0 \mathrm{H}), 7.48(\mathrm{~d}, J=8.7 \mathrm{~Hz}, 1 \mathrm{H}), 7.38-7.28(\mathrm{~m}, 1 \mathrm{H}), 7.20(\mathrm{~d}, J=1.6 \mathrm{~Hz}, 1 \mathrm{H})$, 7.08 (q, $J=2.6 \mathrm{~Hz}, 1 \mathrm{H}$ ), 6.99 (ddd, $J=9.0,4.5,2.6 \mathrm{~Hz}, 2 \mathrm{H}), 5.58-5.49(\mathrm{~m}, 1 \mathrm{H}), 4.54(\mathrm{t}, J=2.3 \mathrm{~Hz}, 2 \mathrm{H}), 3.53-3.43(\mathrm{~m}, 2 \mathrm{H}), 3.43-$ $3.35(\mathrm{~m}, 2 \mathrm{H}), 2.84-2.76(\mathrm{~m}, 1 \mathrm{H}), 1.86(\mathrm{tt}, J=6.7,3.5 \mathrm{~Hz}, 2 \mathrm{H}), 1.62(\mathrm{dd}, J=6.4,1.6 \mathrm{~Hz}, 3 \mathrm{H}), 1.33-1.23(\mathrm{~m}, 3 \mathrm{H})$.

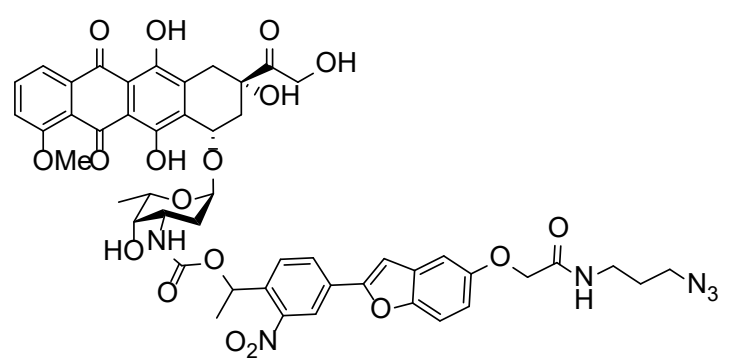

\section{$\mathrm{N}_{3}$-NPBF-Doxo conjugate (46).}

Compound $45(31 \mu \mathrm{mol}, 13.7 \mathrm{mg})$ and NHS-carbonate $(45 \mu \mathrm{mol}, 11.5 \mathrm{mg})$ were dissolved in dry MeCN $(1 \mathrm{~mL})$ in an Eppendorf tube. DiPEA (120 $\mu \mathrm{mol}$, $21 \mu \mathrm{L}$ ) was then added and the mixture was shaken for $6 \mathrm{~h}$ covered from light. Doxorubicin (60 $\mu \mathrm{mol}, 35 \mathrm{mg}$ ) was added and the shaking was continued for $16 \mathrm{~h}$. The solvent was removed and the crude was purified by column chromatography twice (MeOH in DCM $-0 \%$ to $4 \% \mathrm{v} / \mathrm{v}$ and acetone in toluene $-40 \%$ to $50 \% \mathrm{v} / \mathrm{v}$ ) to give $\mathbf{4 6}$ as a red solid ( $13 \mu \mathrm{mol}, 13.1 \mathrm{mg}$, 42\%). LC-MS (linear gradient $10 \rightarrow 90 \% \mathrm{MeCN}, 0.1 \%$ TFA, $15 \mathrm{~min}): \mathrm{Rt}(\mathrm{min}): 8.07$ (ESI-MS (m/z): $1008.87\left(\mathrm{M}+\mathrm{H}^{+}\right)$). ${ }^{1} \mathrm{H} \mathrm{NMR}(500$ $\left.\mathrm{MHz}, \mathrm{CDCl}_{3}\right) \delta 8.03-7.98(\mathrm{~m}, 1 \mathrm{H}), 8.01-7.90(\mathrm{~m}, 2 \mathrm{H}), 7.90-7.85(\mathrm{~m}, 1 \mathrm{H}), 7.76(\mathrm{dt}, J=22.5,8.0 \mathrm{~Hz}, 2 \mathrm{H}), 7.47(\mathrm{~d}, J=8.9 \mathrm{~Hz}, 1 \mathrm{H})$, $7.41-7.30(\mathrm{~m}, 2 \mathrm{H}), 7.25(\mathrm{~d}, J=7.5 \mathrm{~Hz}, 1 \mathrm{H}), 7.20-7.13(\mathrm{~m}, 2 \mathrm{H}), 7.07-7.01(\mathrm{~m}, 1 \mathrm{H}), 6.97(\mathrm{dd}, J=9.0,2.6 \mathrm{~Hz}, 1 \mathrm{H}), 6.89(\mathrm{~d}, J=8.3$ $\mathrm{Hz}, 2 \mathrm{H}), 6.23(\mathrm{~s}, 1 \mathrm{H}), 5.51-5.44(\mathrm{~m}, 1 \mathrm{H}), 5.39(\mathrm{dd}, J=8.8,4.2 \mathrm{~Hz}, 1 \mathrm{H}), 5.23(\mathrm{~d}, J=10.4 \mathrm{~Hz}, 1 \mathrm{H}), 4.73(\mathrm{~s}, 1 \mathrm{H}), 4.69(\mathrm{~d}, J=6.4 \mathrm{~Hz}$, $1 \mathrm{H}), 4.54(\mathrm{~s}, 1 \mathrm{H}), 4.49(\mathrm{~s}, 1 \mathrm{H}), 4.08(\mathrm{~s}, 2 \mathrm{H}), 4.04(\mathrm{~s}, 1 \mathrm{H}), 4.00(\mathrm{~s}, 2 \mathrm{H}), 3.82(\mathrm{~d}, J=11.4 \mathrm{~Hz}, 1 \mathrm{H}), 3.73(\mathrm{p}, J=6.7 \mathrm{~Hz}, 1 \mathrm{H}), 3.59(\mathrm{~s}, 1 \mathrm{H})$, $3.47(\mathrm{p}, J=6.6 \mathrm{~Hz}, 3 \mathrm{H}), 3.39(\mathrm{td}, J=6.5,1.8 \mathrm{~Hz}, 3 \mathrm{H}), 3.22-3.11(\mathrm{~m}, 1 \mathrm{H}), 3.00-2.94(\mathrm{~m}, 2 \mathrm{H}), 2.94-2.81(\mathrm{~m}, 3 \mathrm{H}), 2.70(\mathrm{~s}, 4 \mathrm{H})$, $2.68(\mathrm{~s}, 7 \mathrm{H}), 2.36(\mathrm{~s}, 1 \mathrm{H}), 2.27(\mathrm{~d}, J=15.9 \mathrm{~Hz}, 1 \mathrm{H}), 2.18(\mathrm{~s}, 1 \mathrm{H}), 2.11(\mathrm{td}, J=14.1,4.2 \mathrm{~Hz}, 1 \mathrm{H}), 1.96-1.85(\mathrm{~m}, 1 \mathrm{H}), 1.85(\mathrm{dd}, J=$ 6.6, $2.8 \mathrm{~Hz}, 1 \mathrm{H}), 1.64(\mathrm{dd}, J=6.6,2.7 \mathrm{~Hz}, 4 \mathrm{H}), 1.51-1.38(\mathrm{~m}, 4 \mathrm{H}), 1.35-1.20(\mathrm{~m}, 6 \mathrm{H})$. 


\section{References}

(1) C. Bonini , G. Cristiani , M. Funicello, L. Viggianil; Facile Entry to 4- and 5- Hydroxybenzofuran and to Their Amino Derivatives. Synth. Commun. 2006, 36, 1983

(2) P. Barker, P. Finke, K. Thompson; Preparation and cyclization of aryloxyacetaldehyde acetals; a general synthesis of 2, 3unsubstituted benzofurans. Synth. Commun. 1989, 19, 257

(3) A. Konishi, R. Yasunaga, K. Chiba, M. Yasuda; Synthesis, characterization, and properties of a benzofuran-based cage-shaped borate: photo activation of Lewis acid catalysts. Chem. Commun. 2016, 52, 3348 


\section{5. ${ }^{1} \mathrm{H}-\mathrm{NMR}$ and ${ }^{13} \mathrm{C}$-NMR APT spectra}

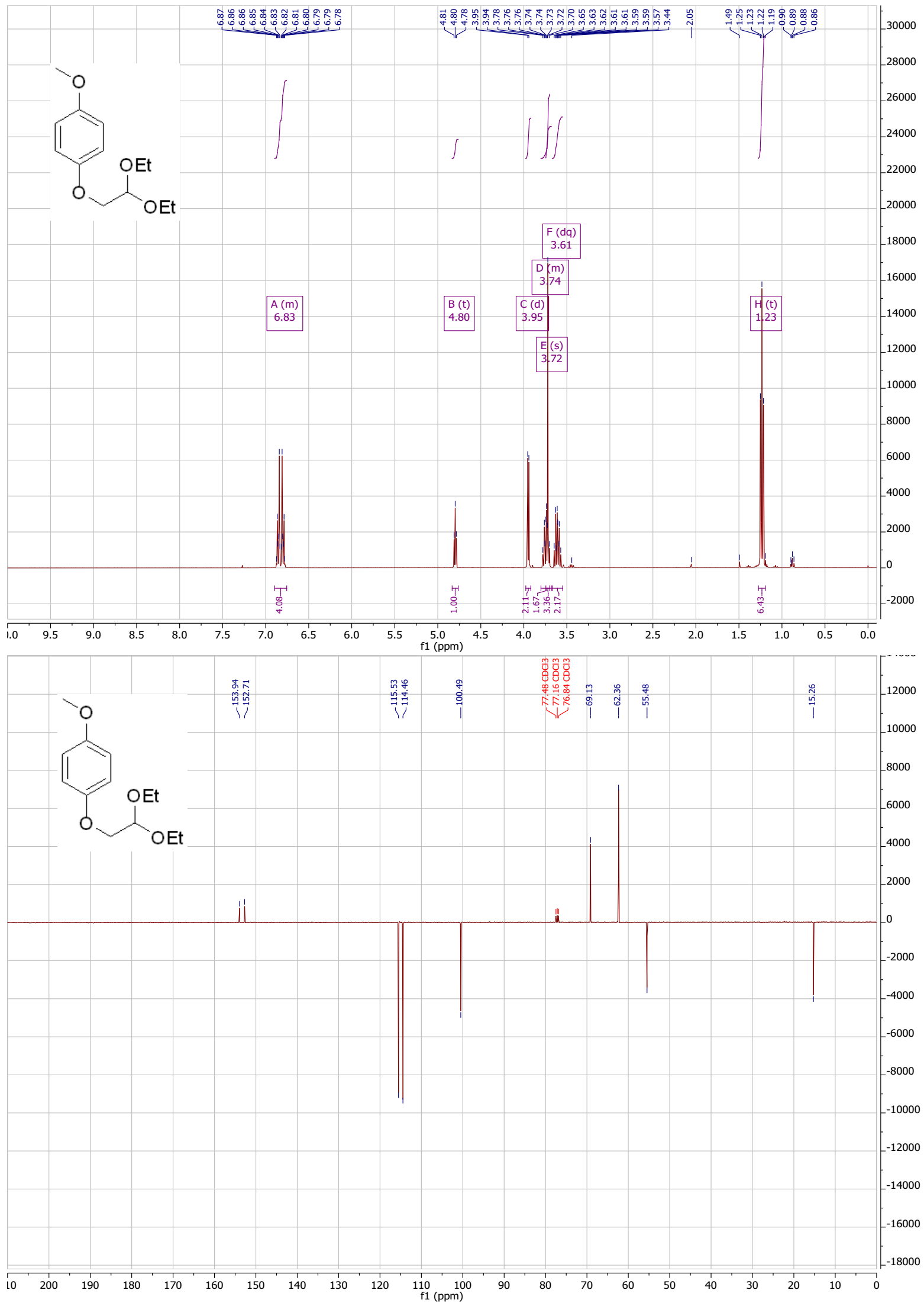




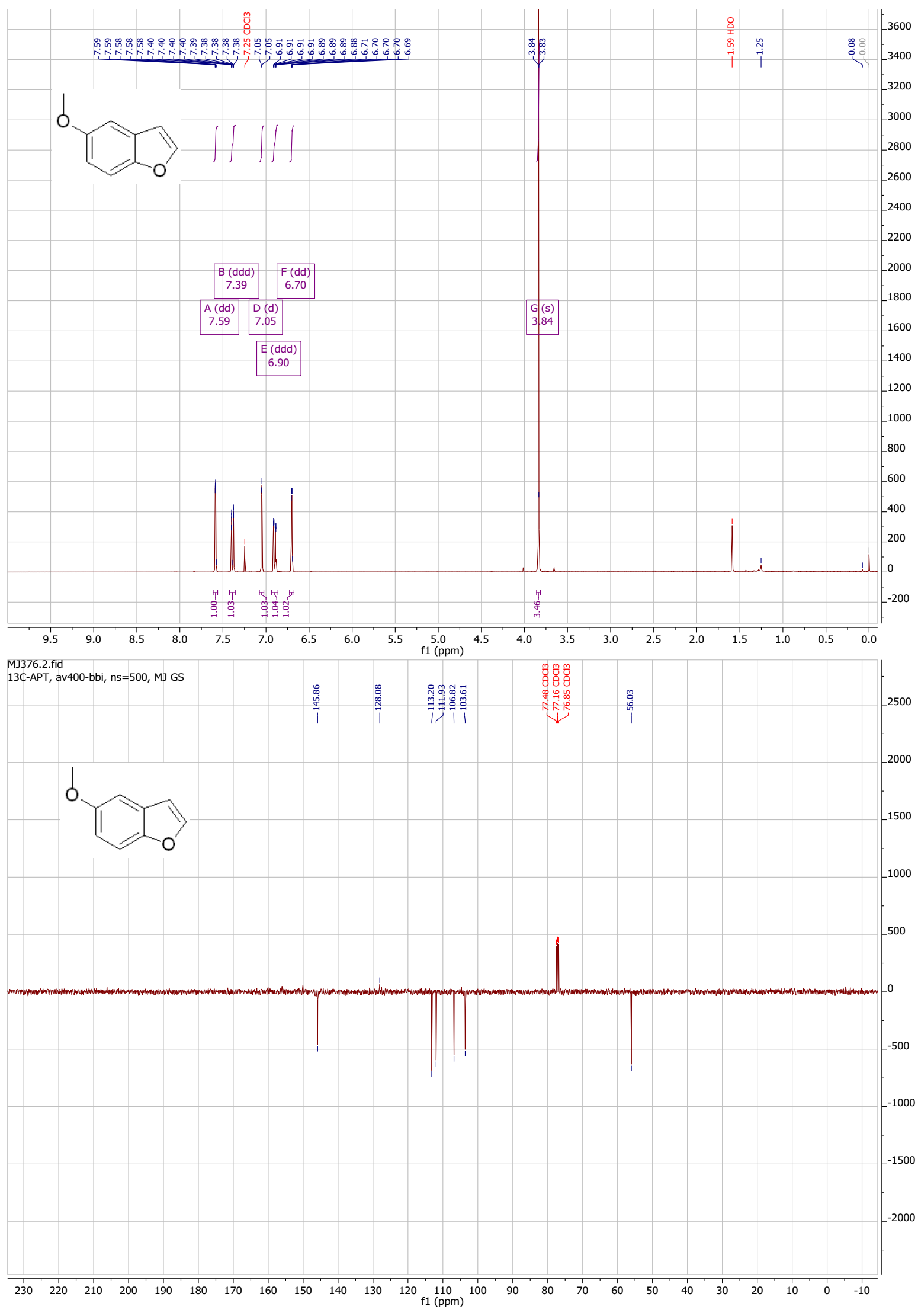




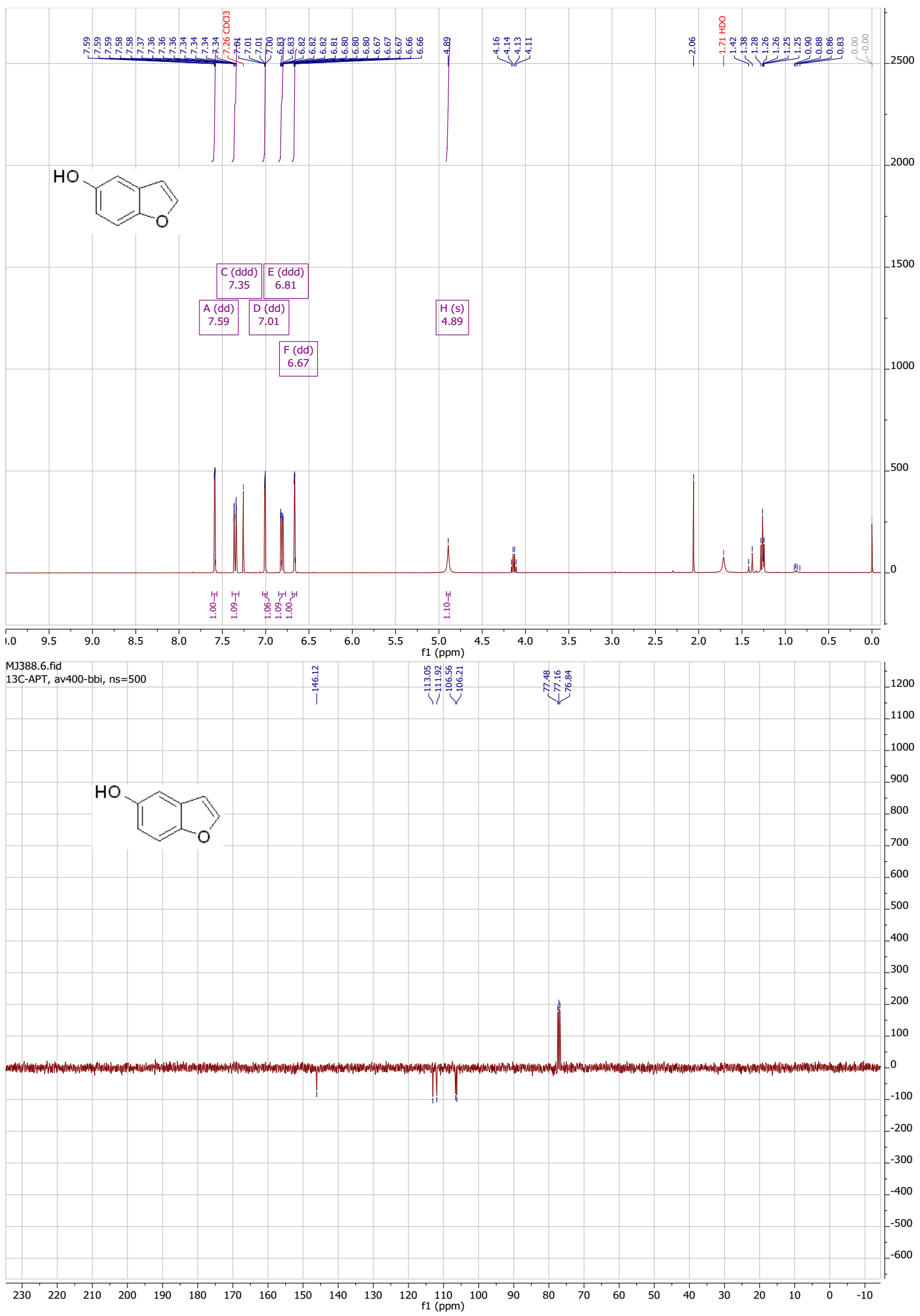




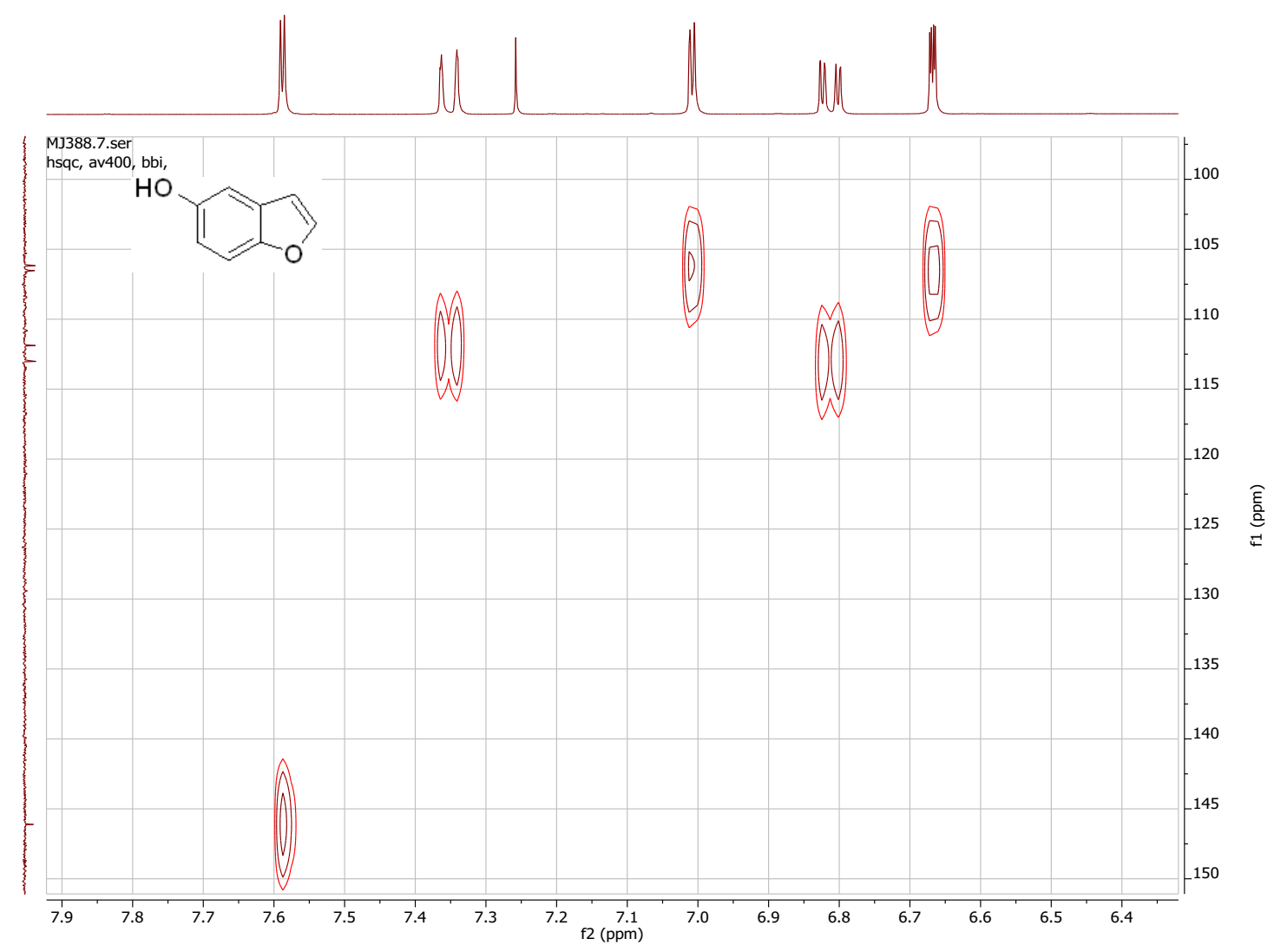




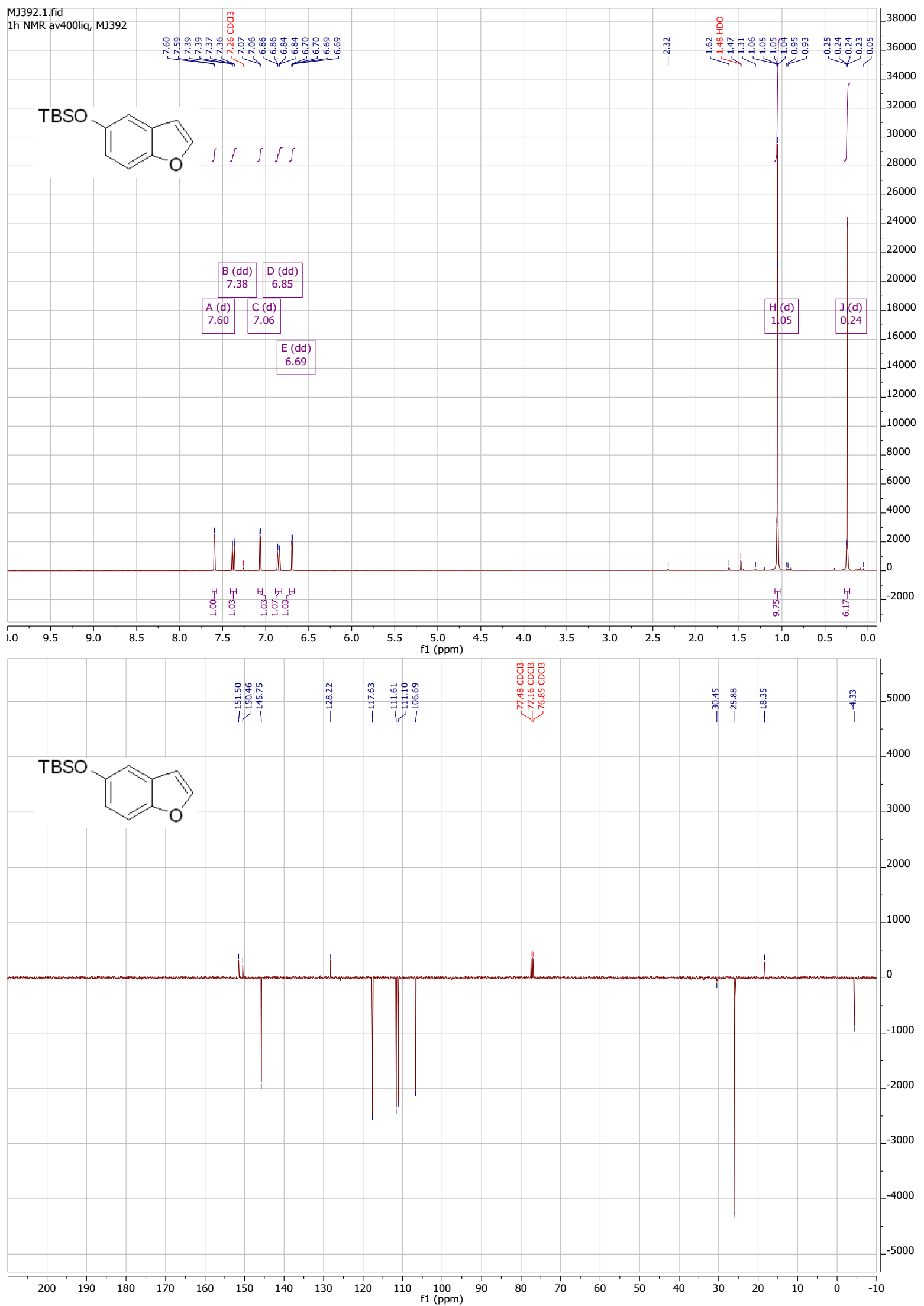




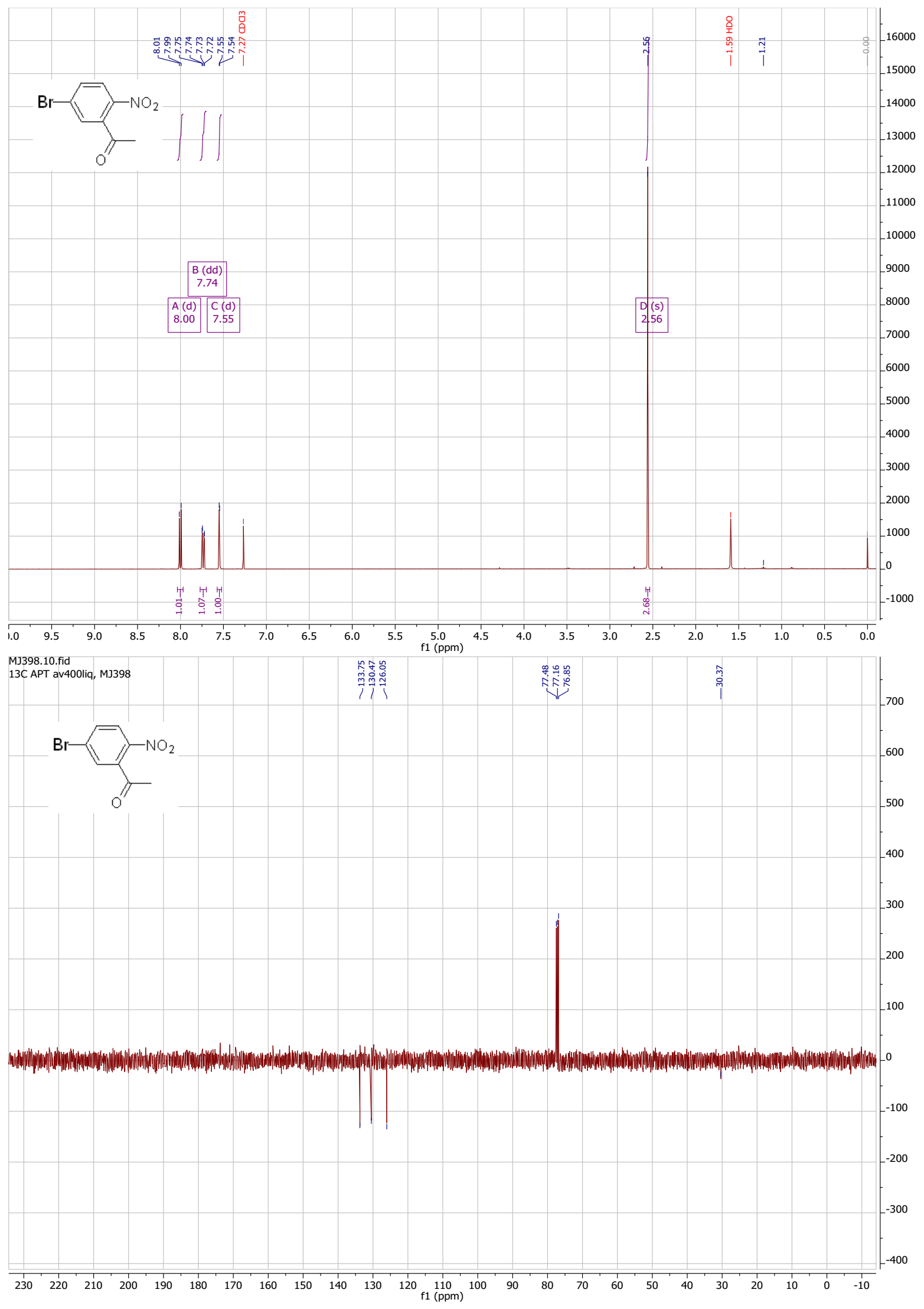




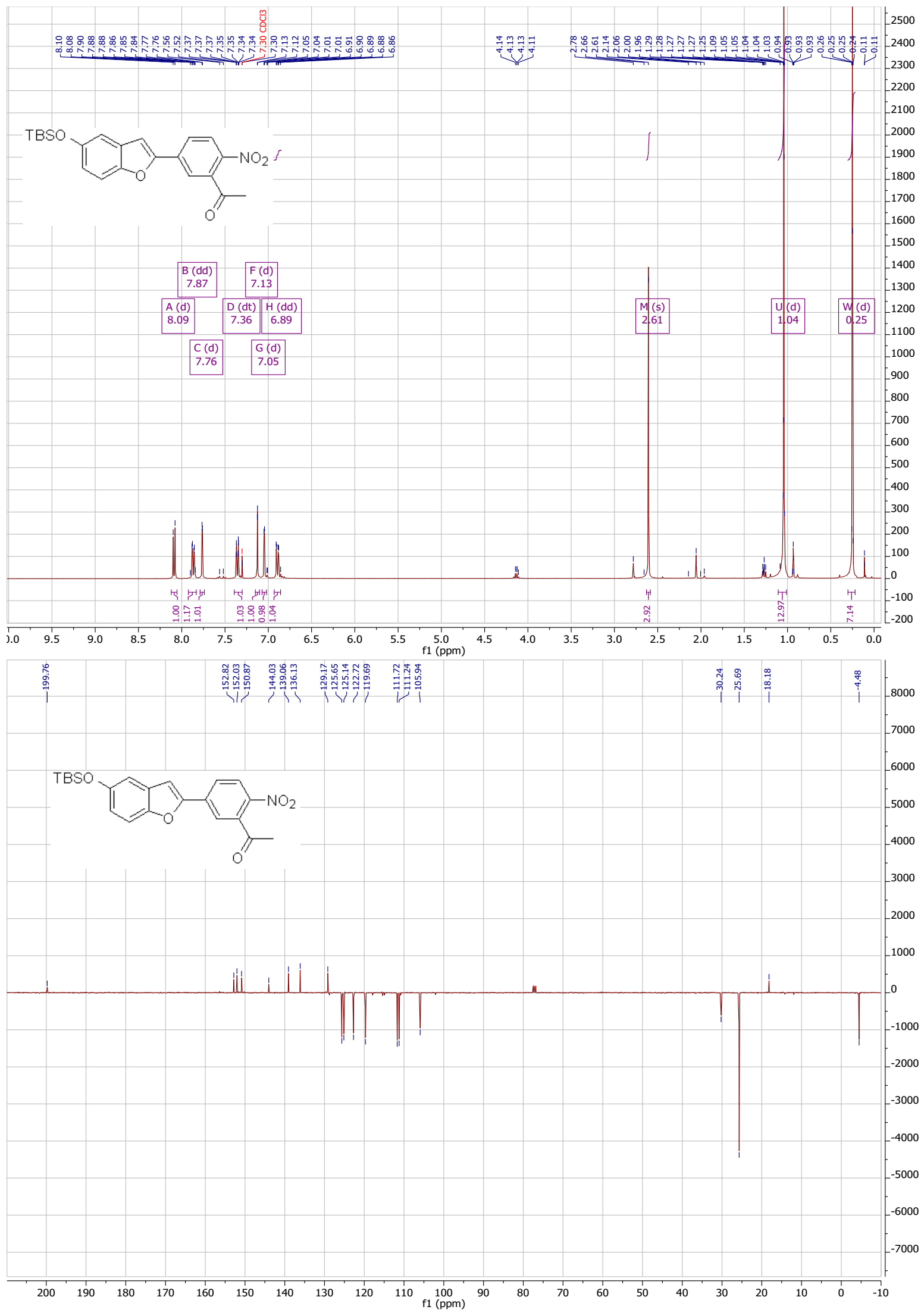




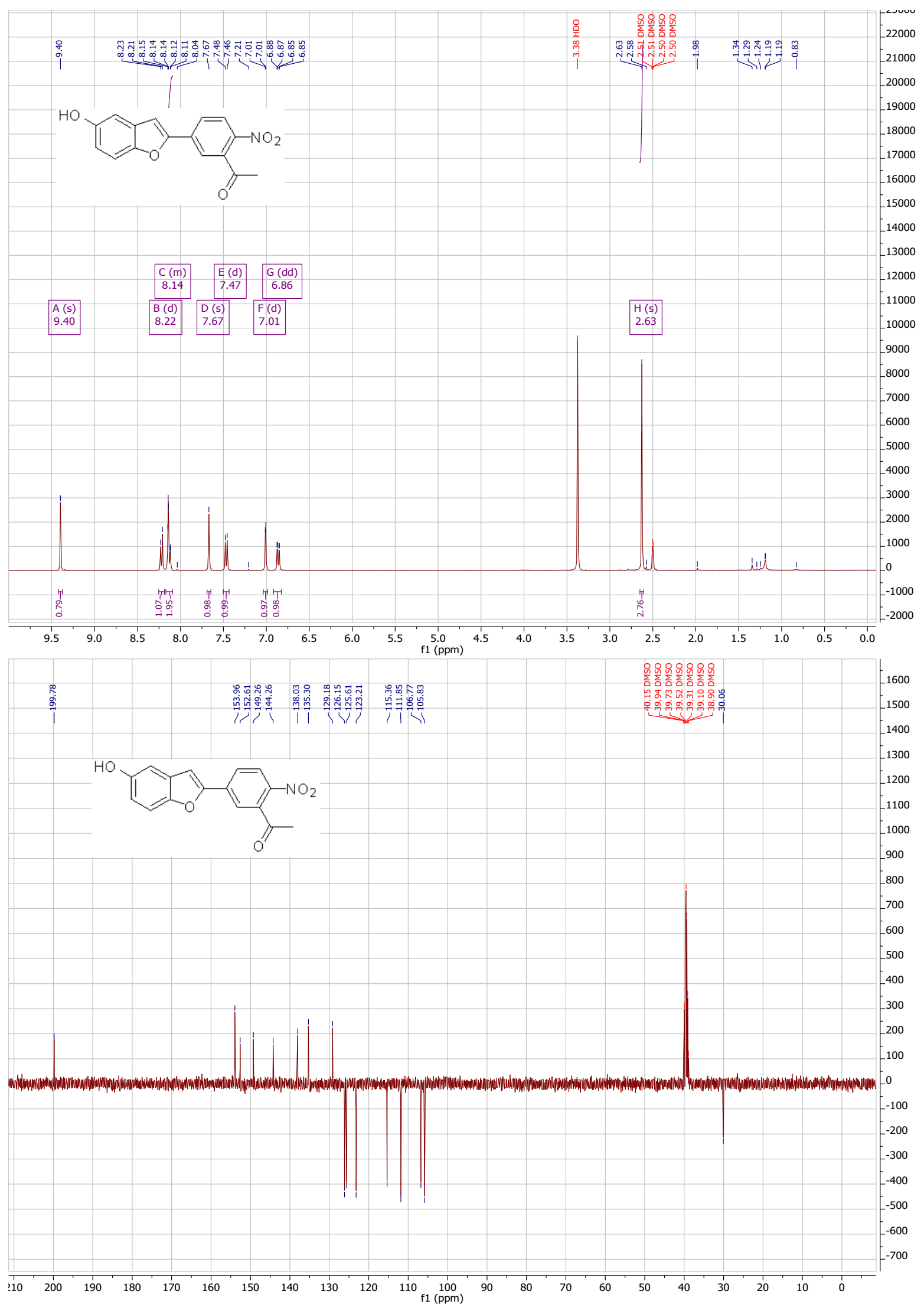




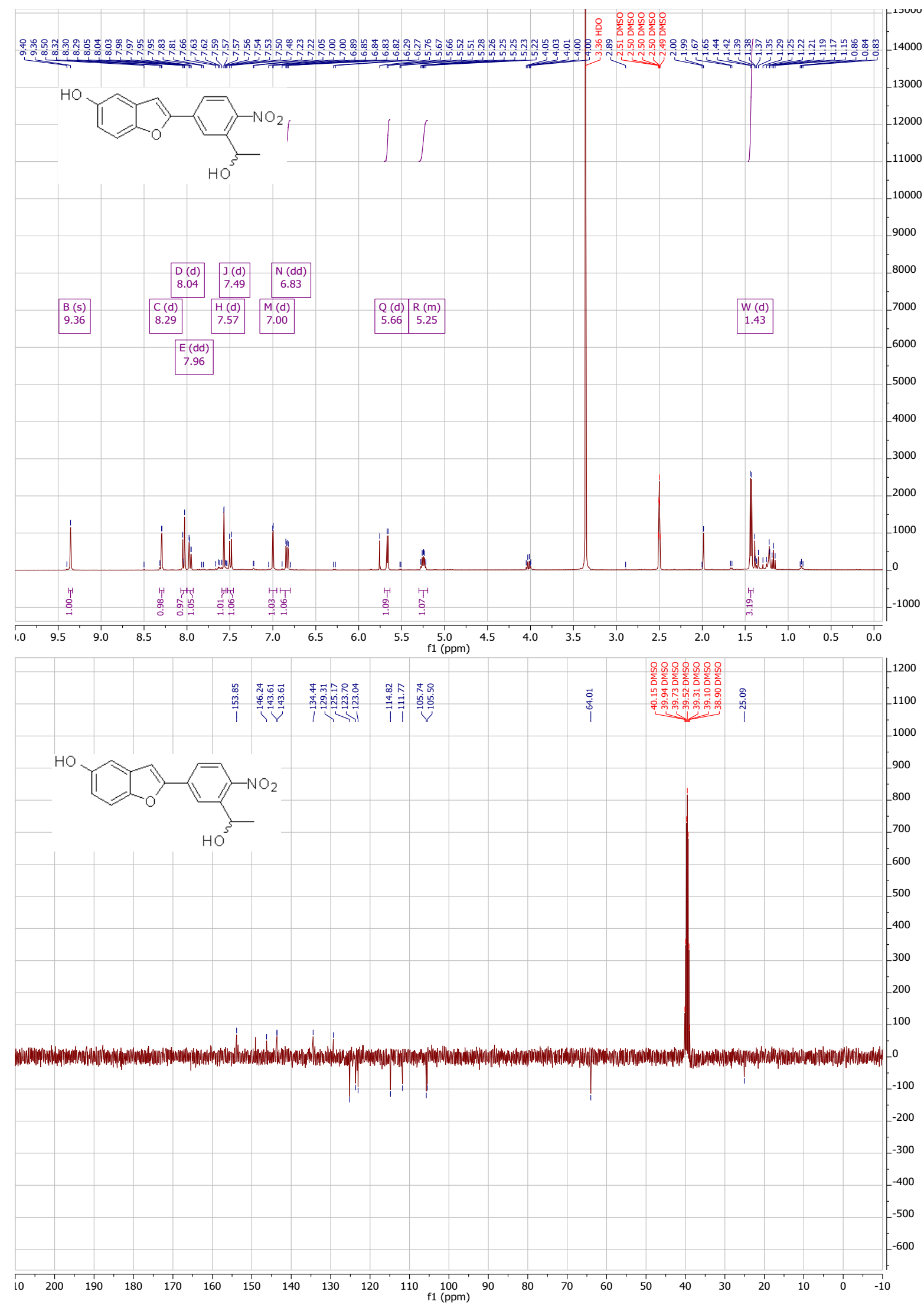




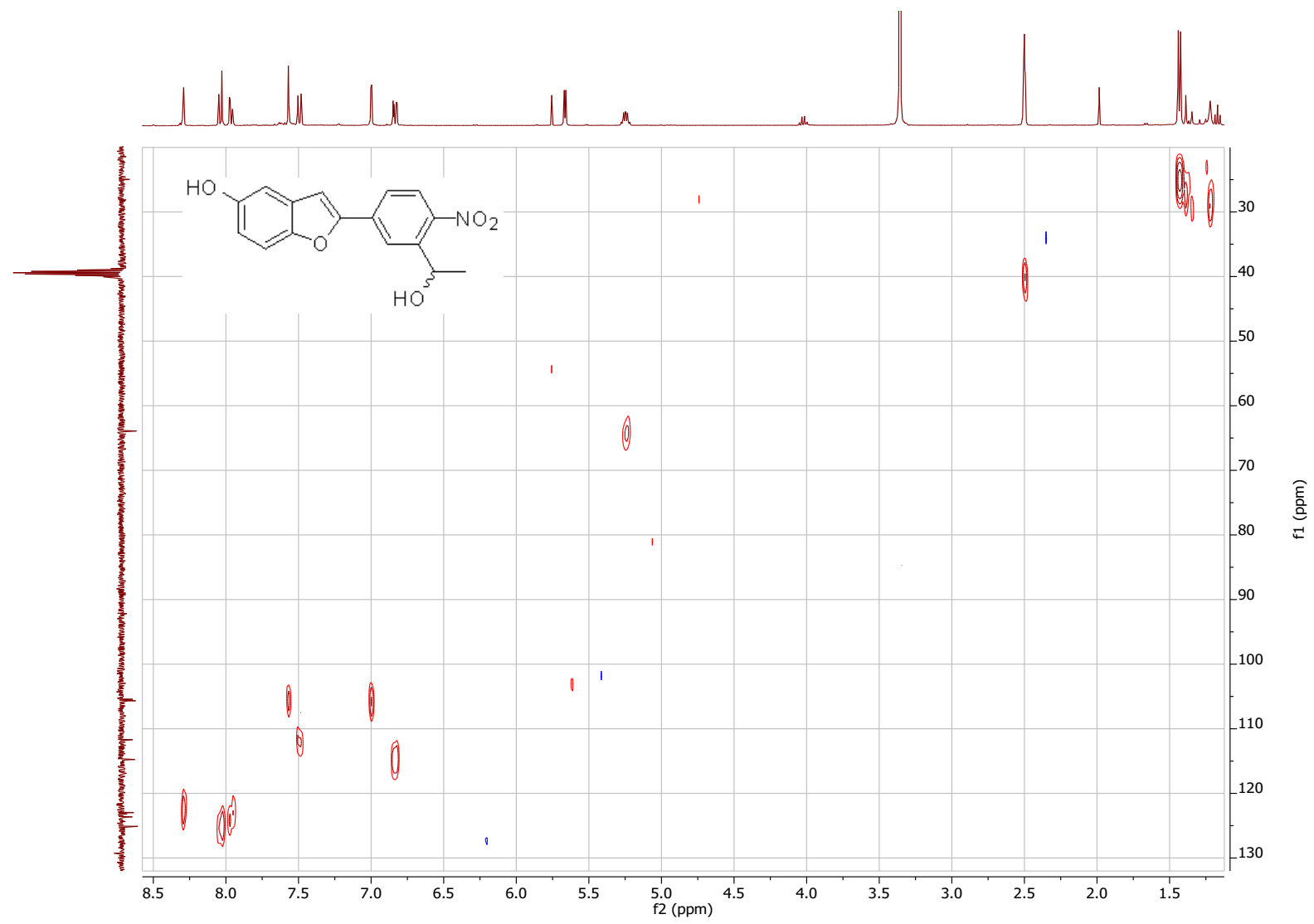




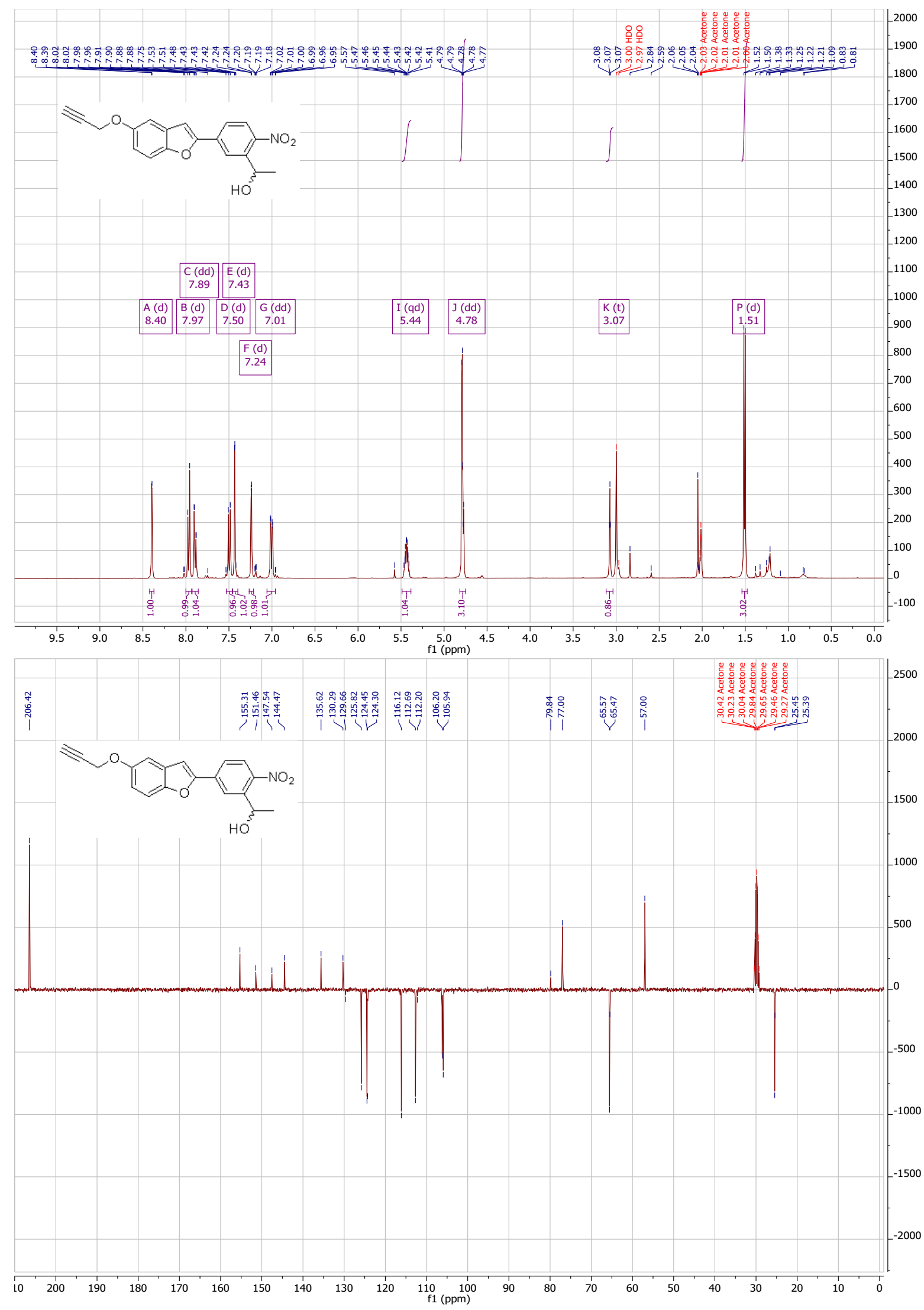




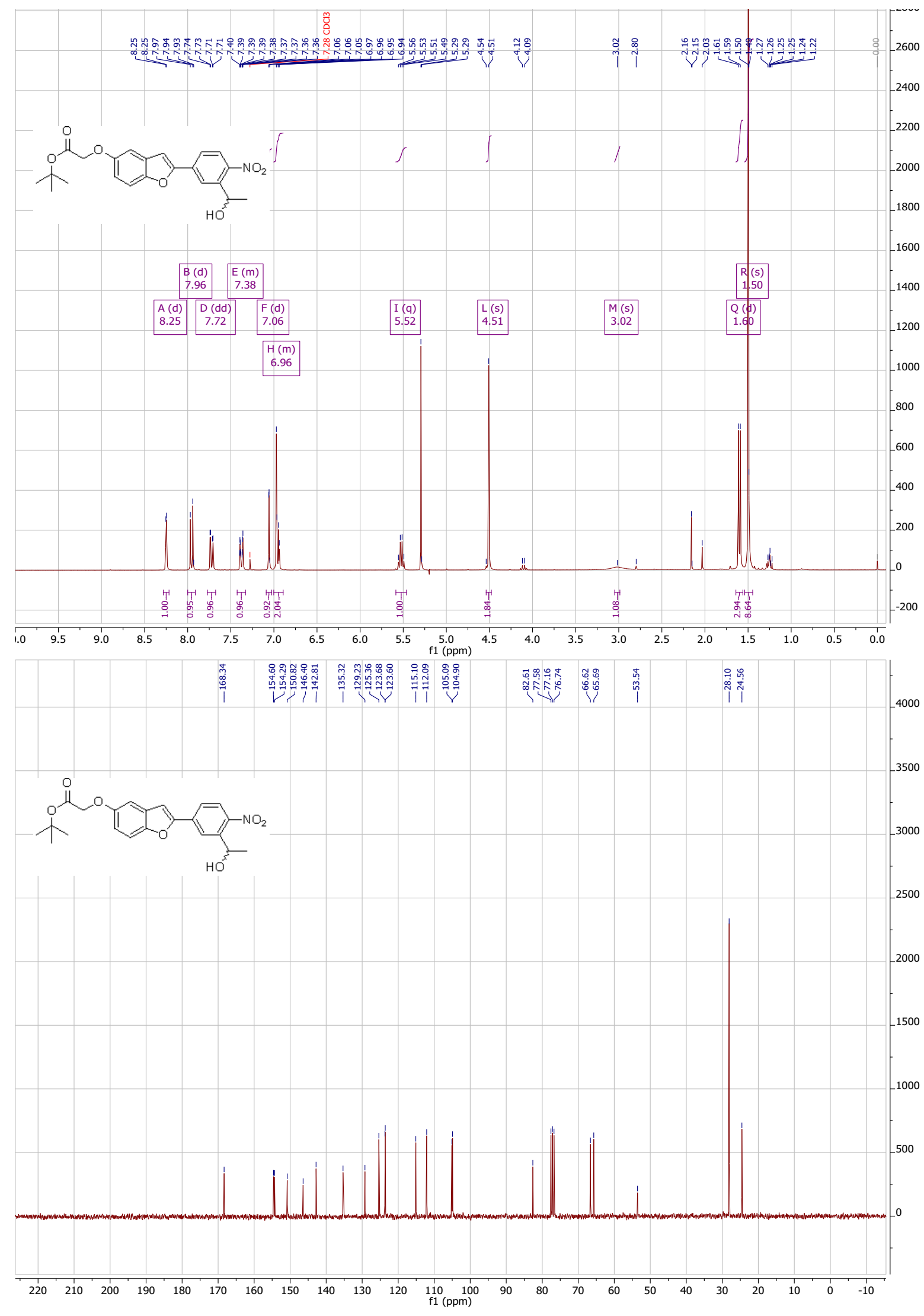




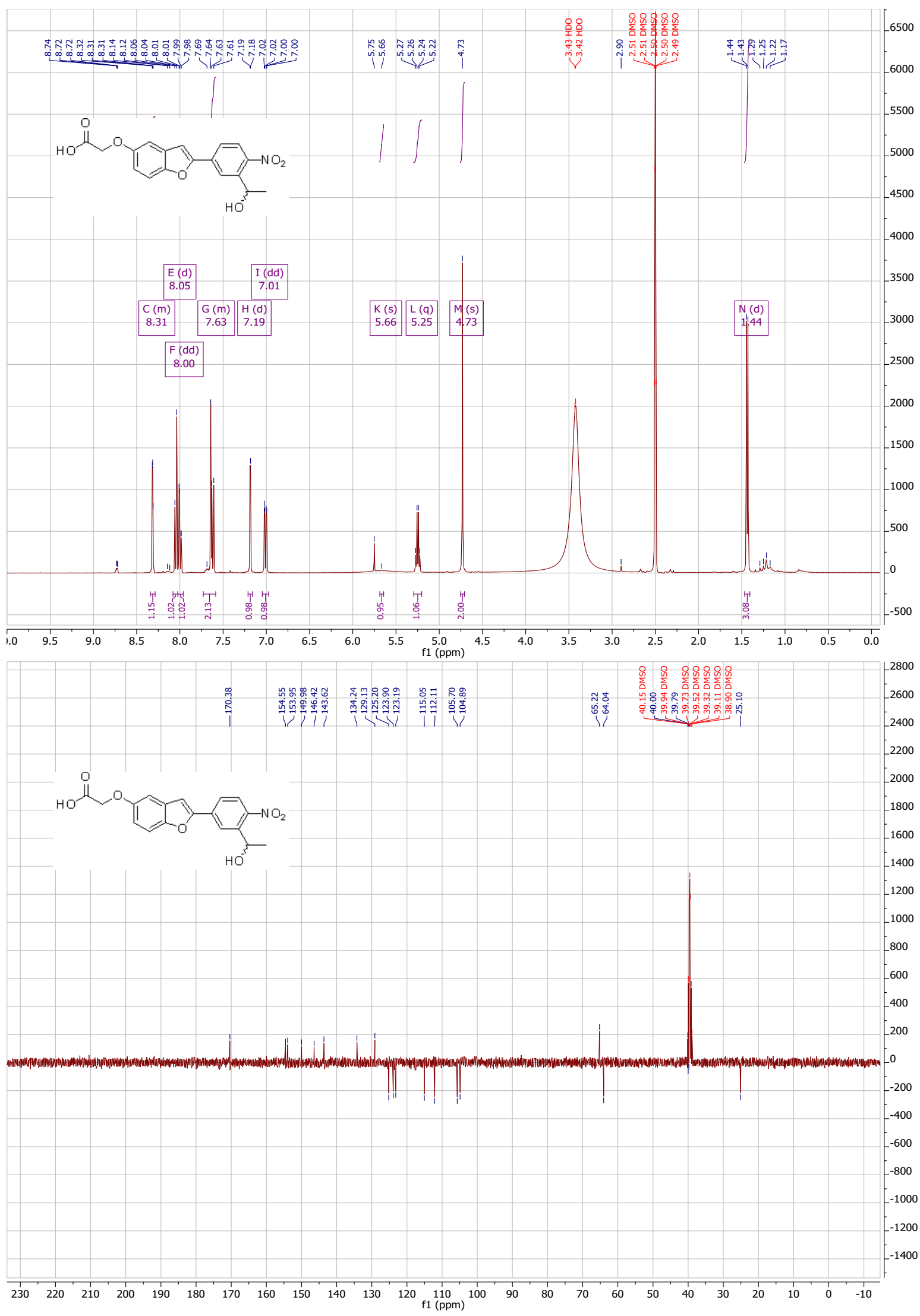




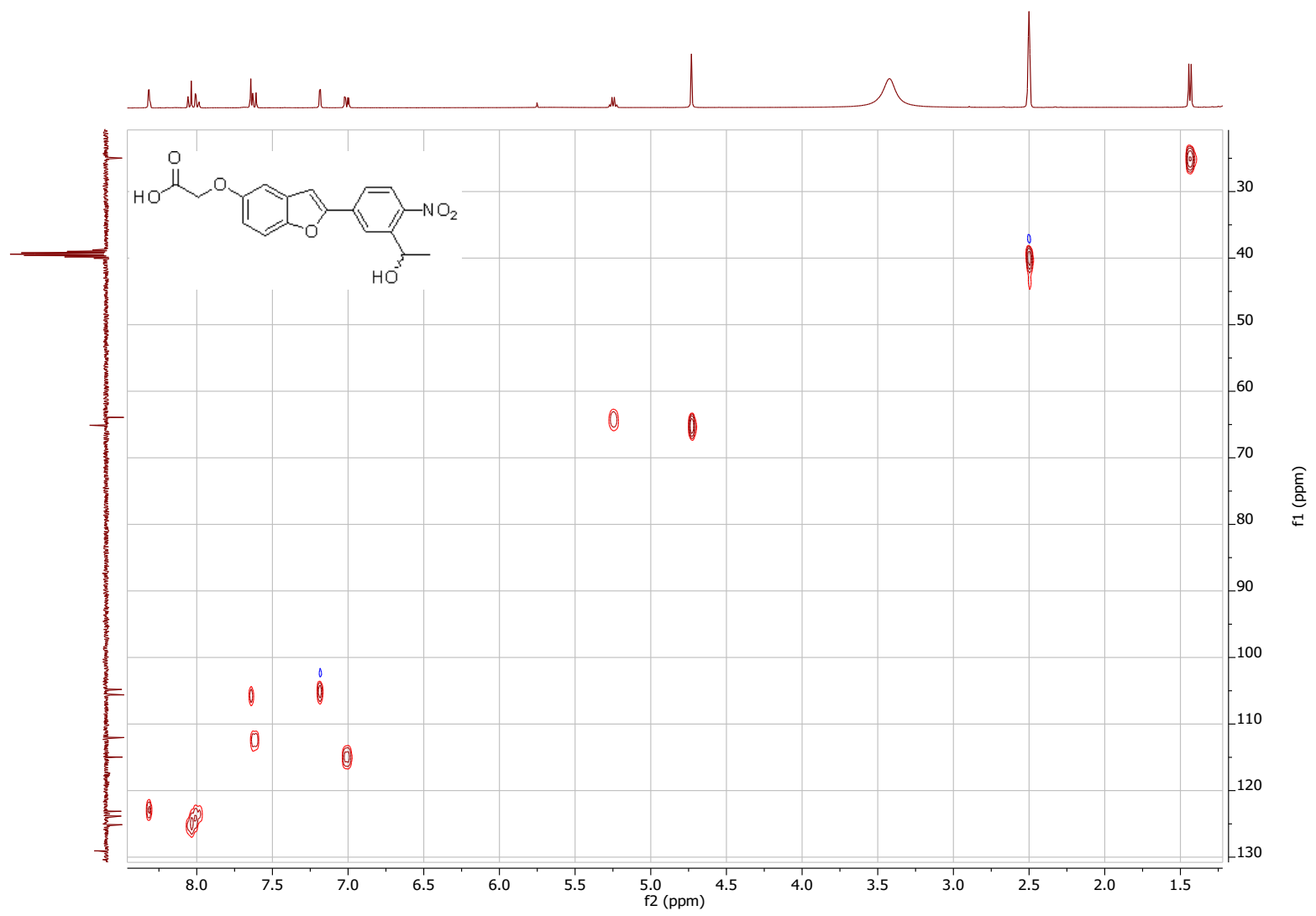




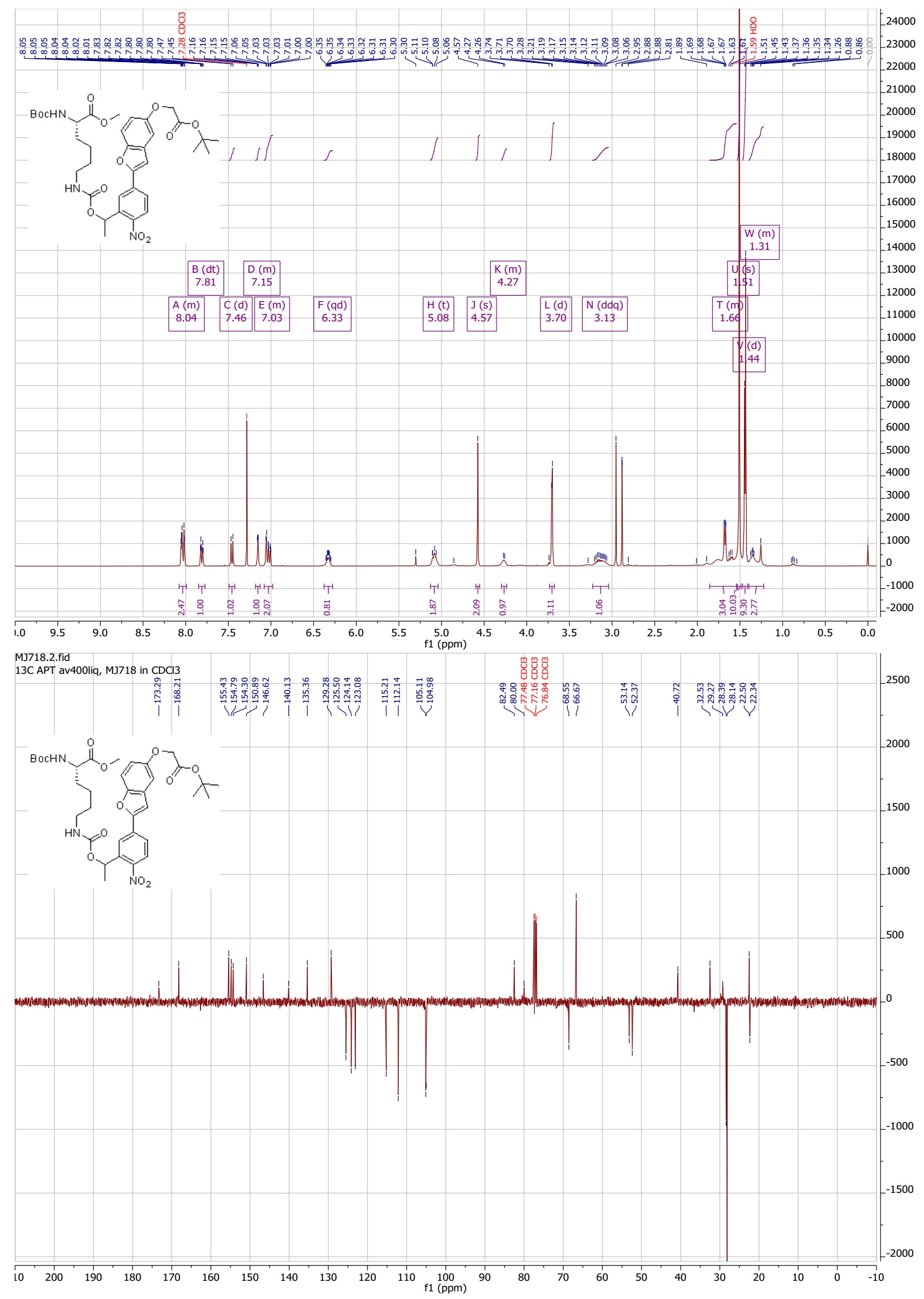




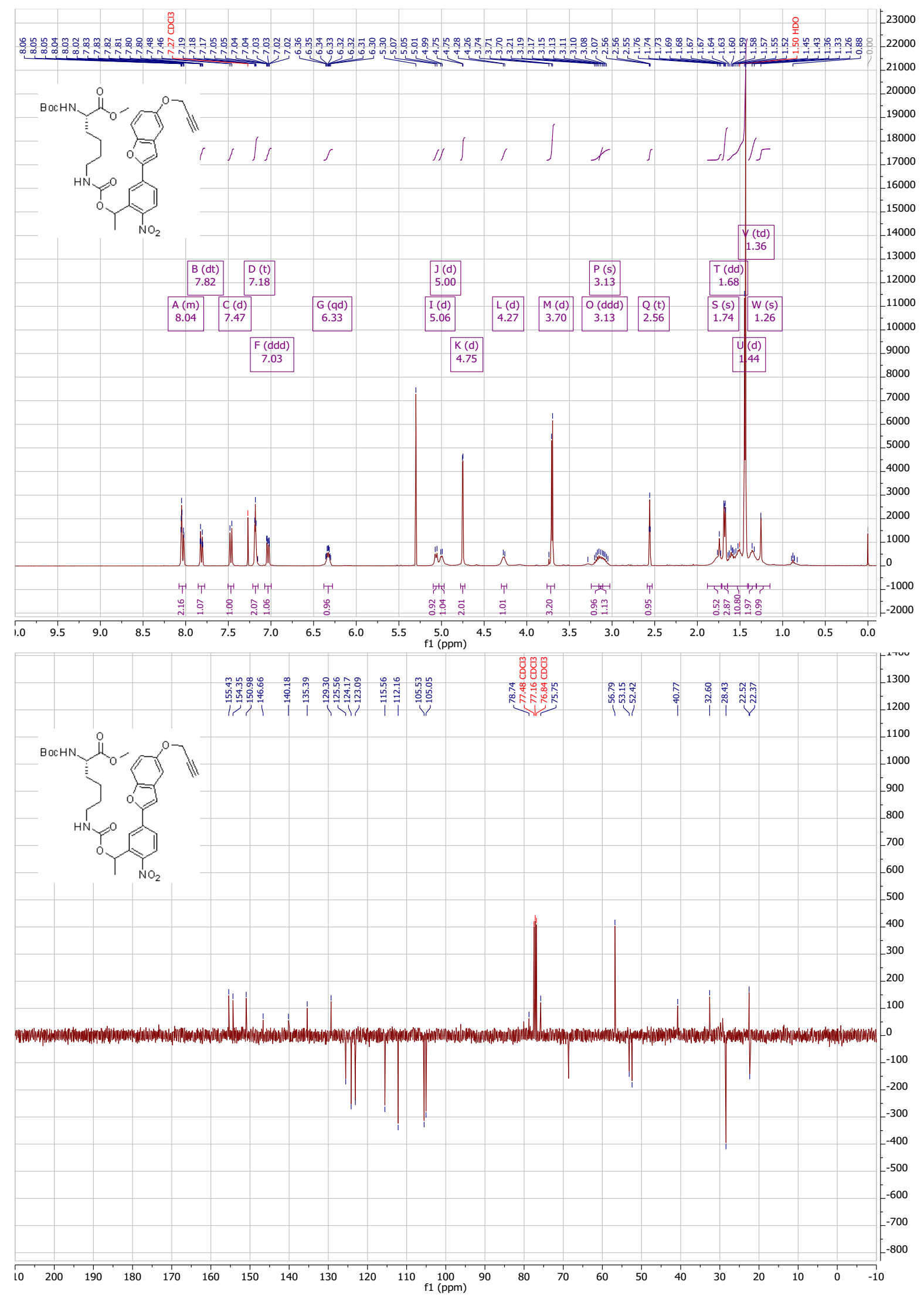




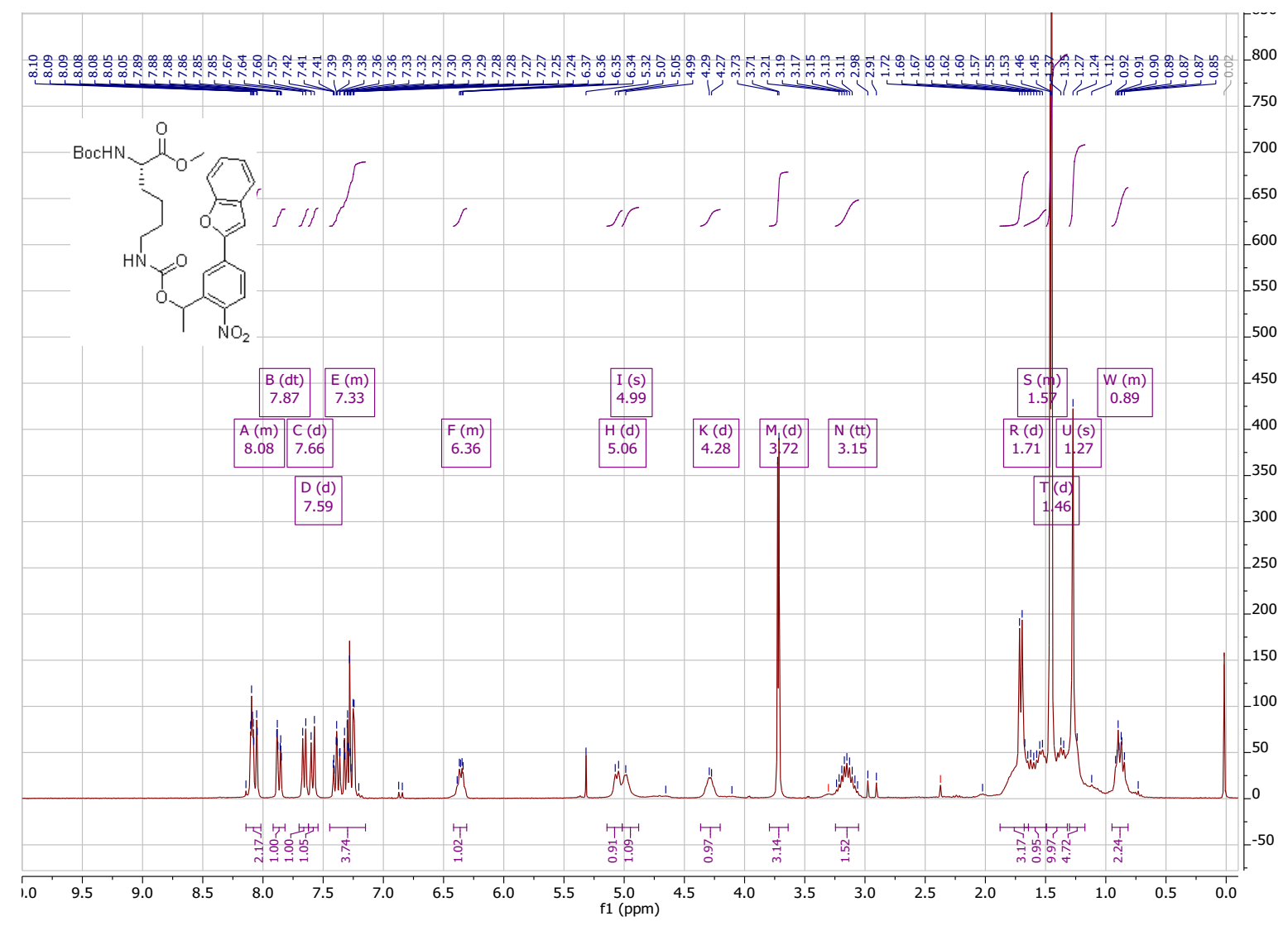




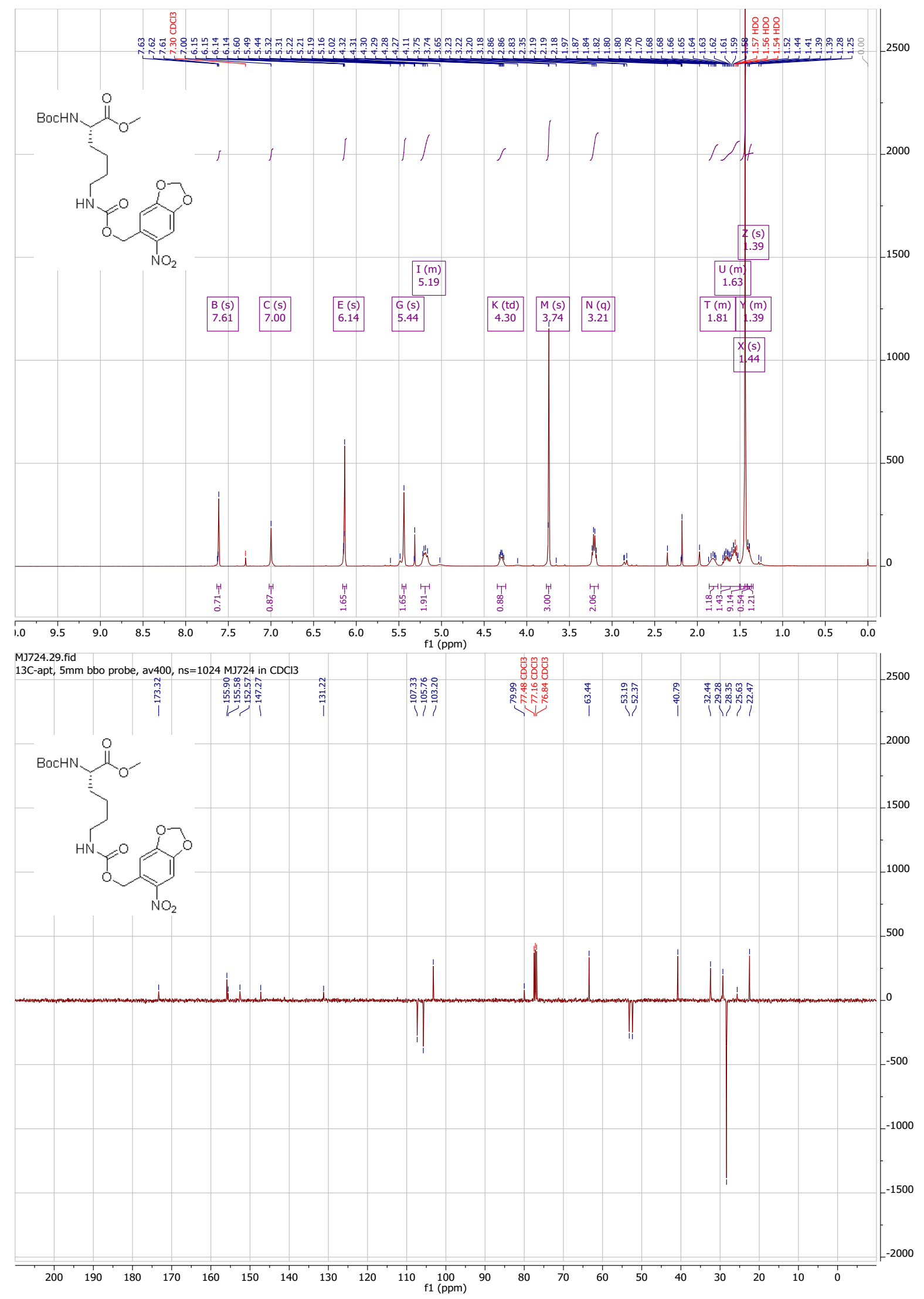




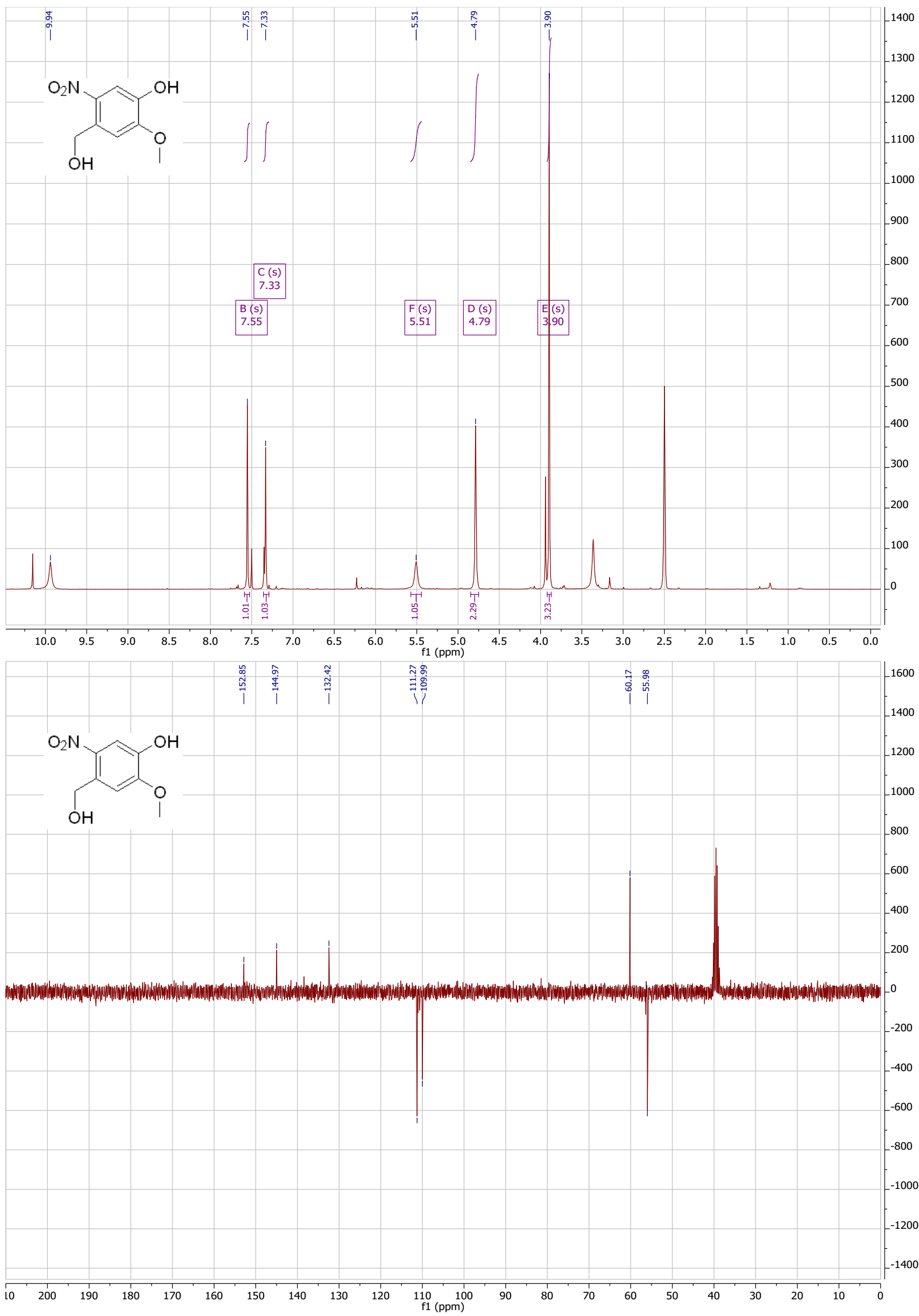




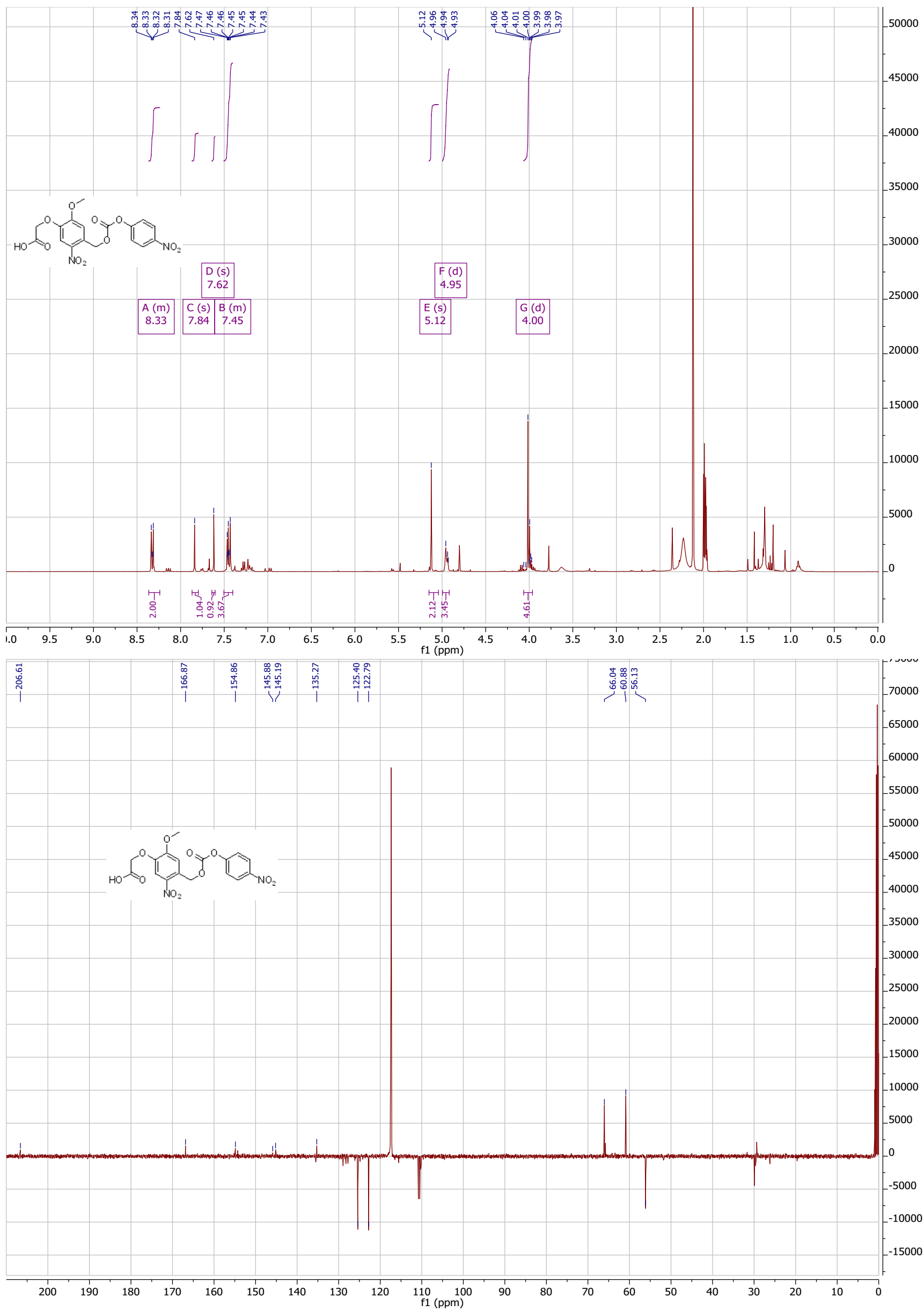




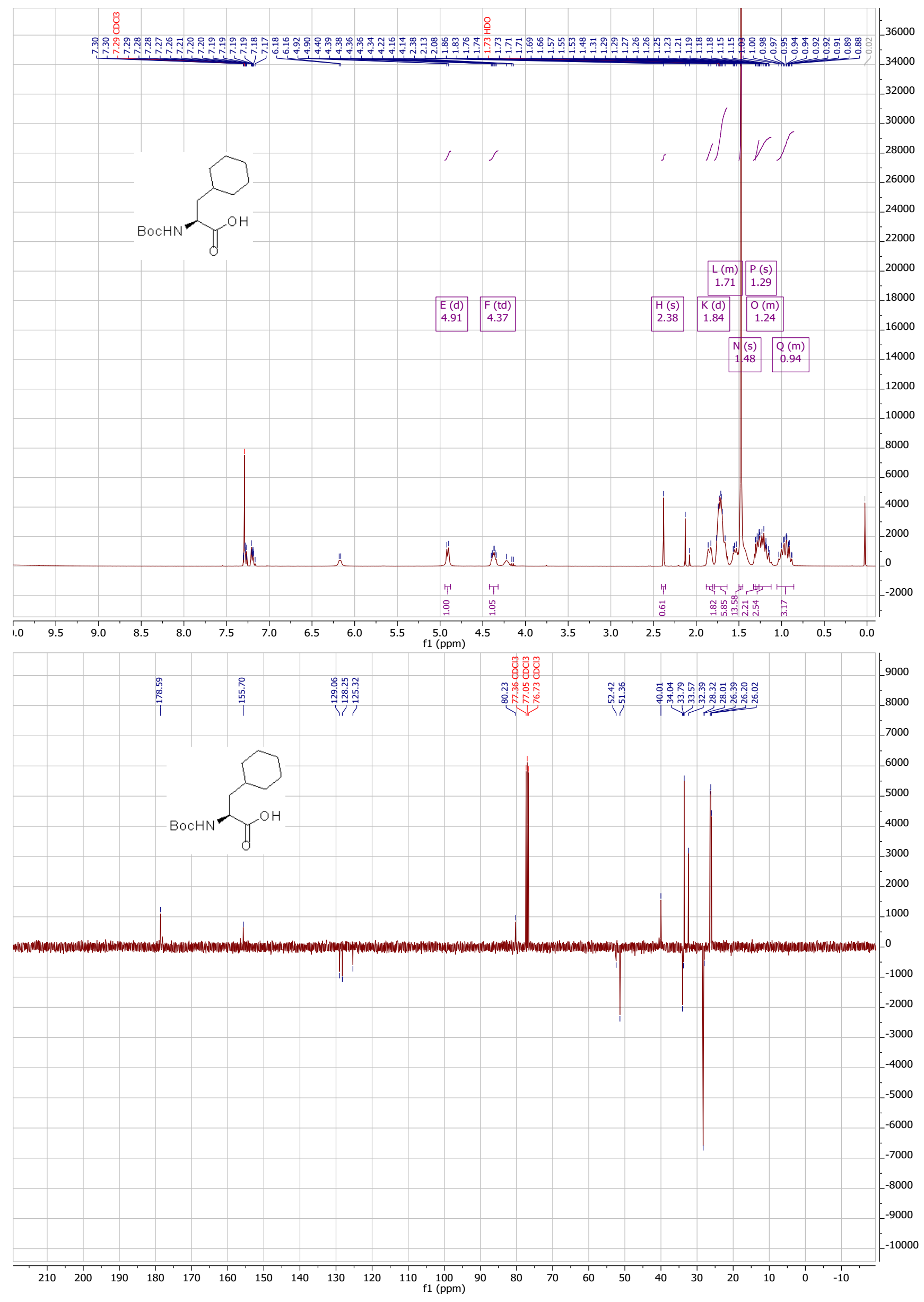




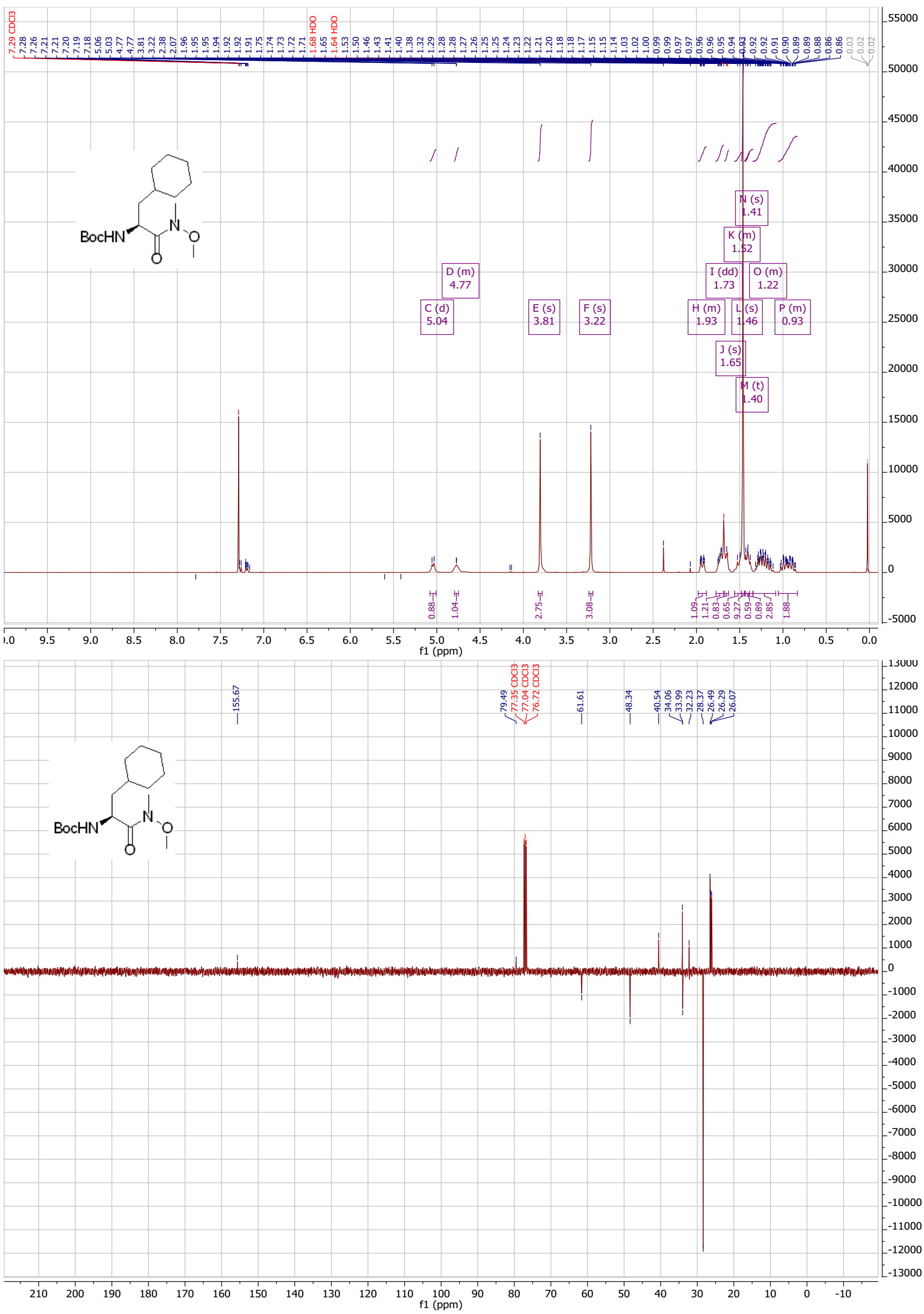




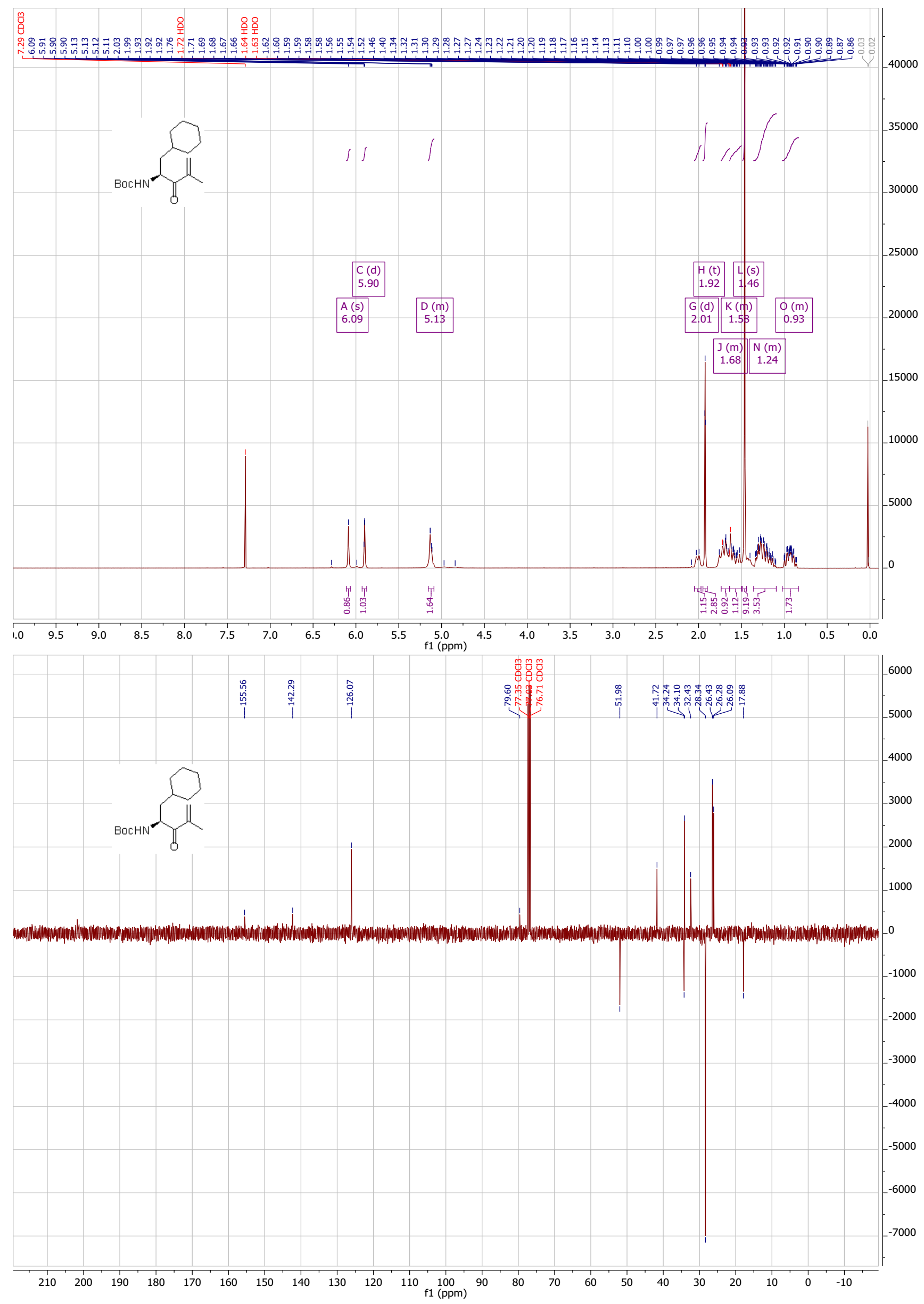




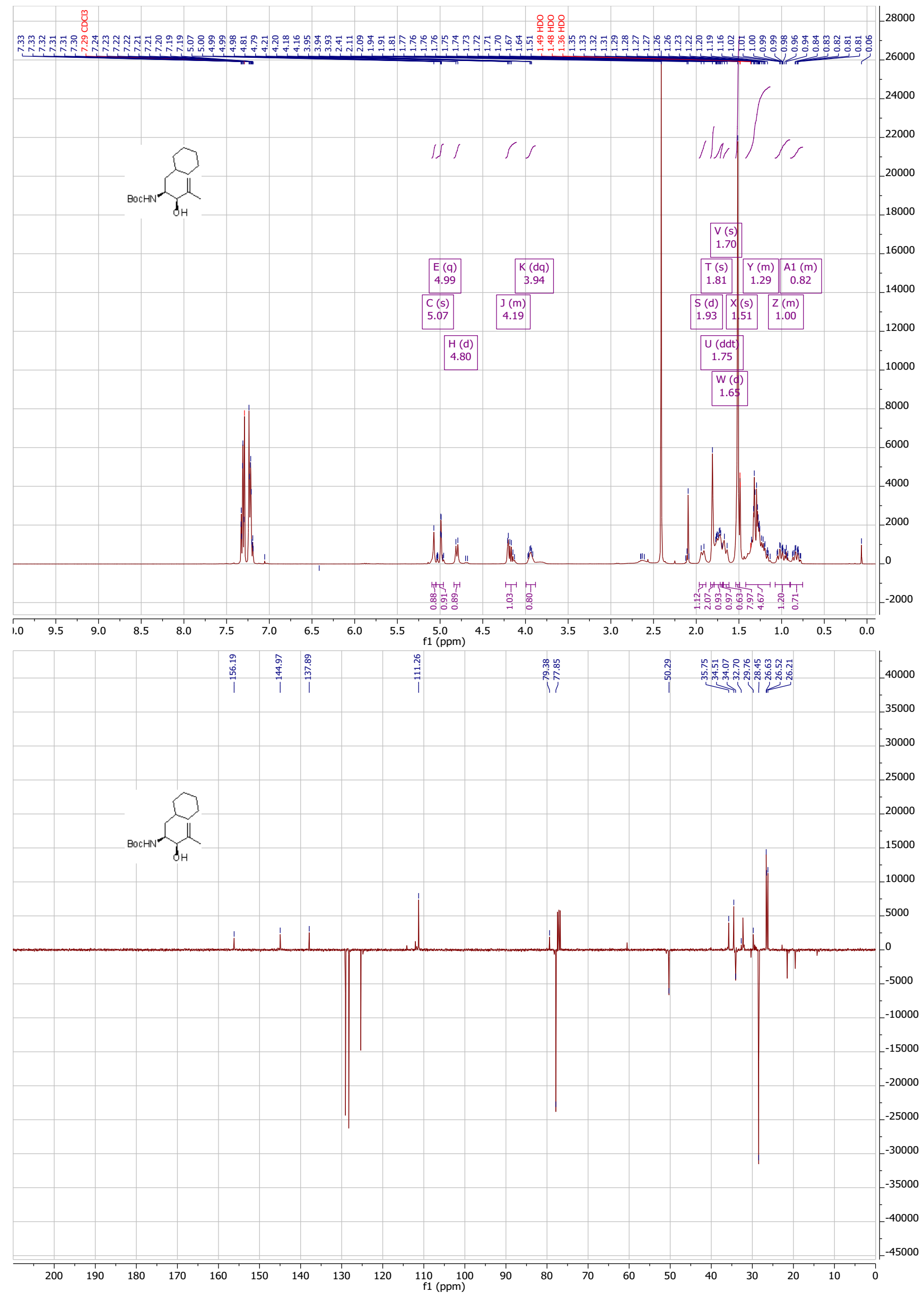




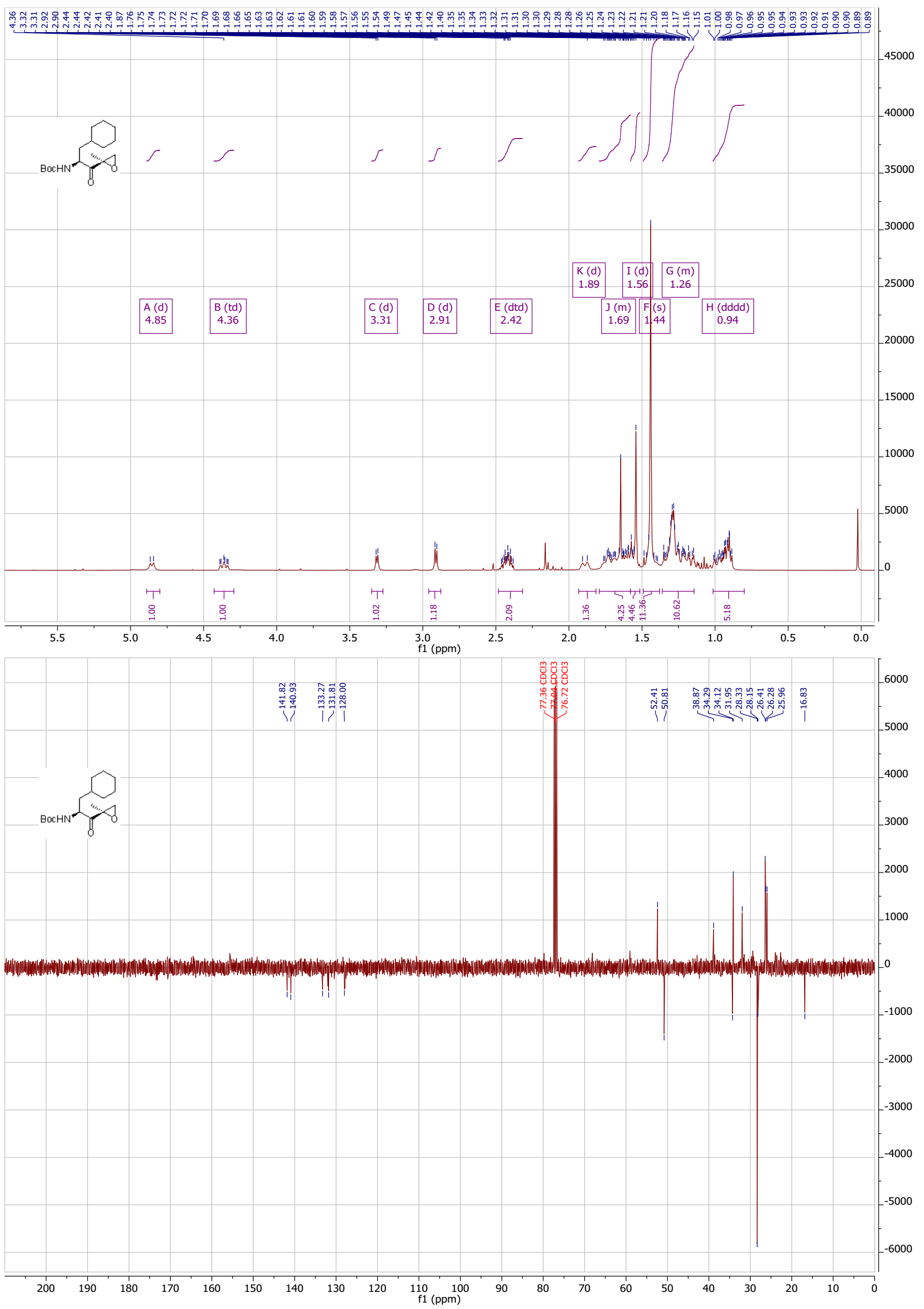




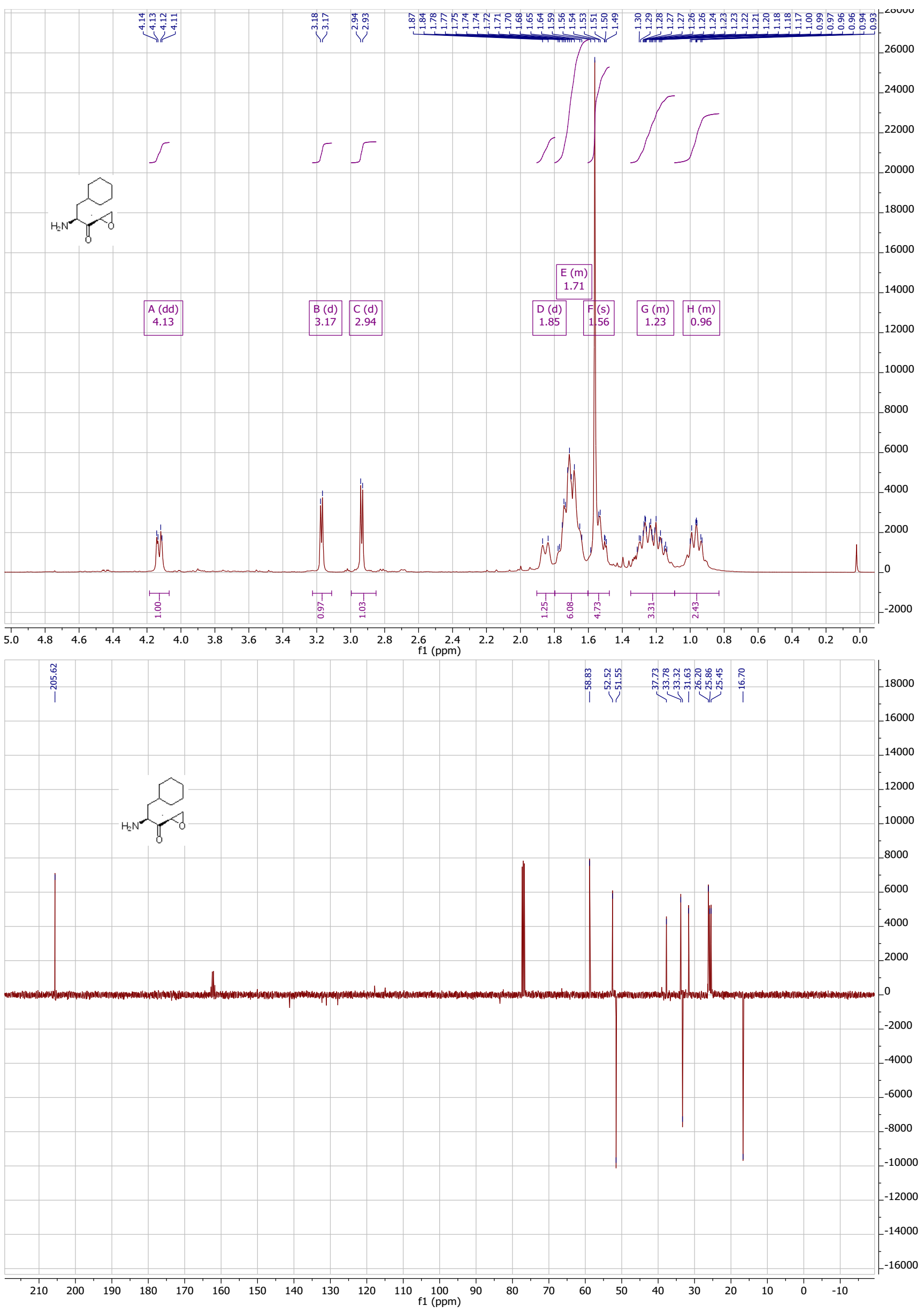




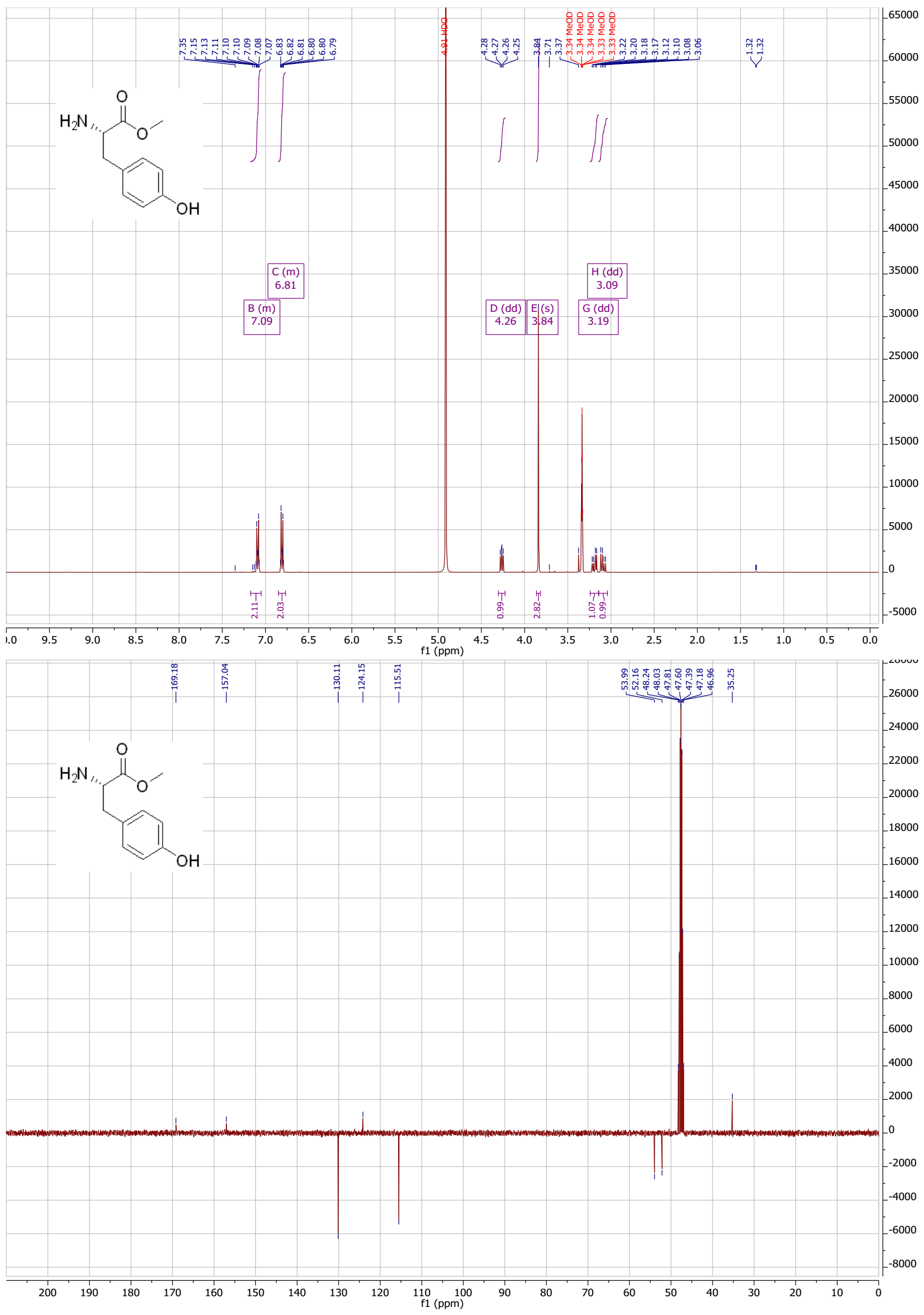




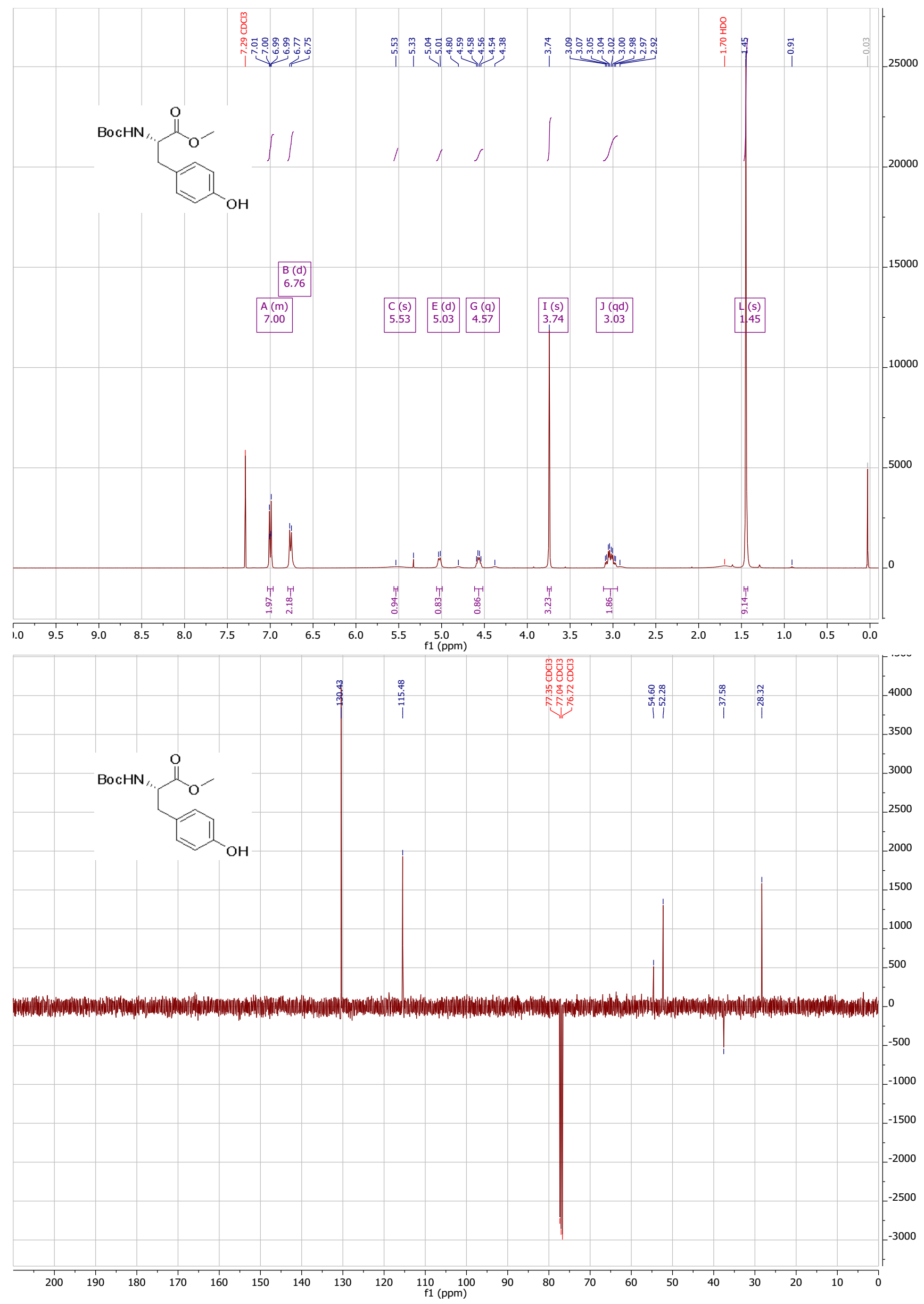




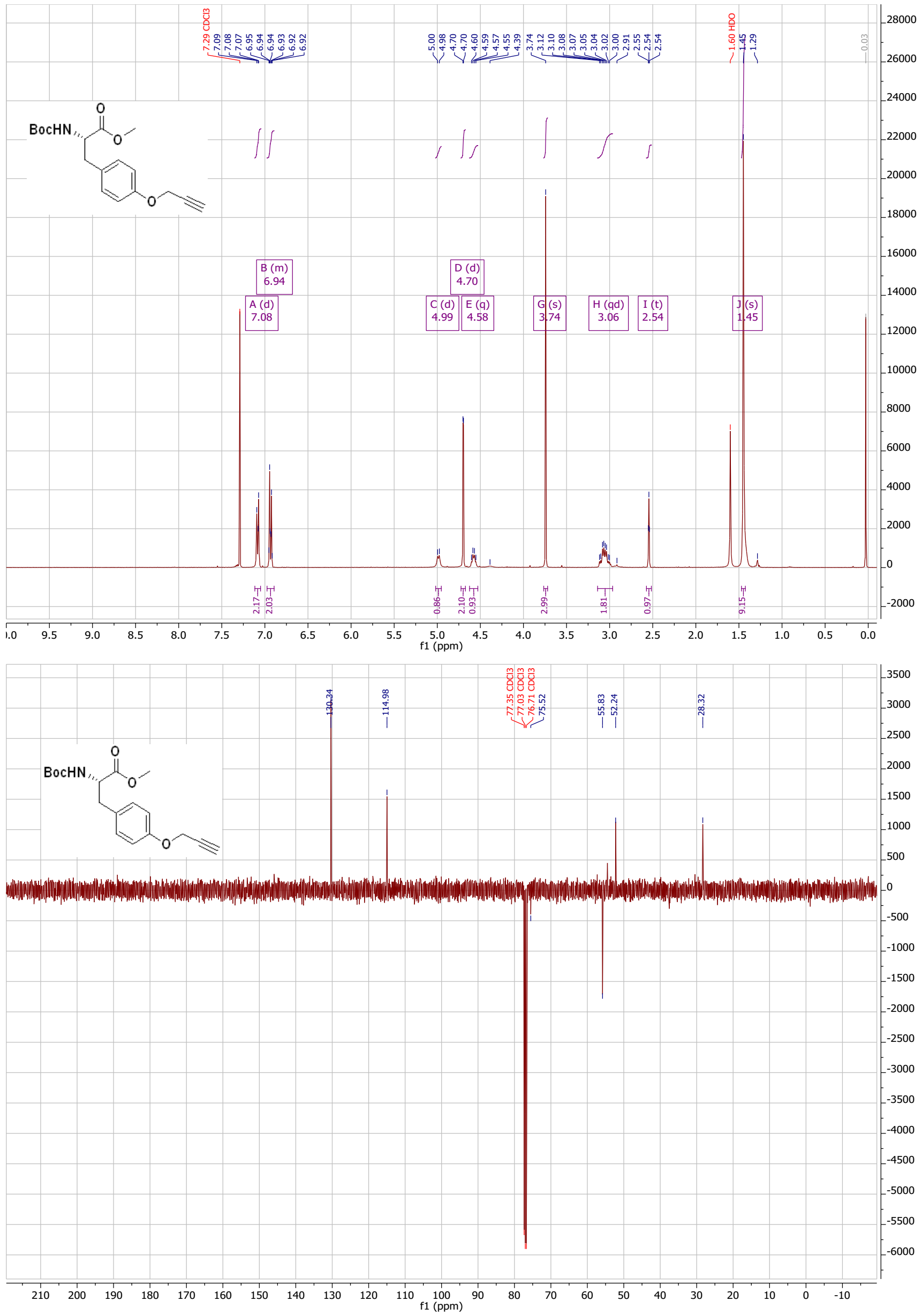




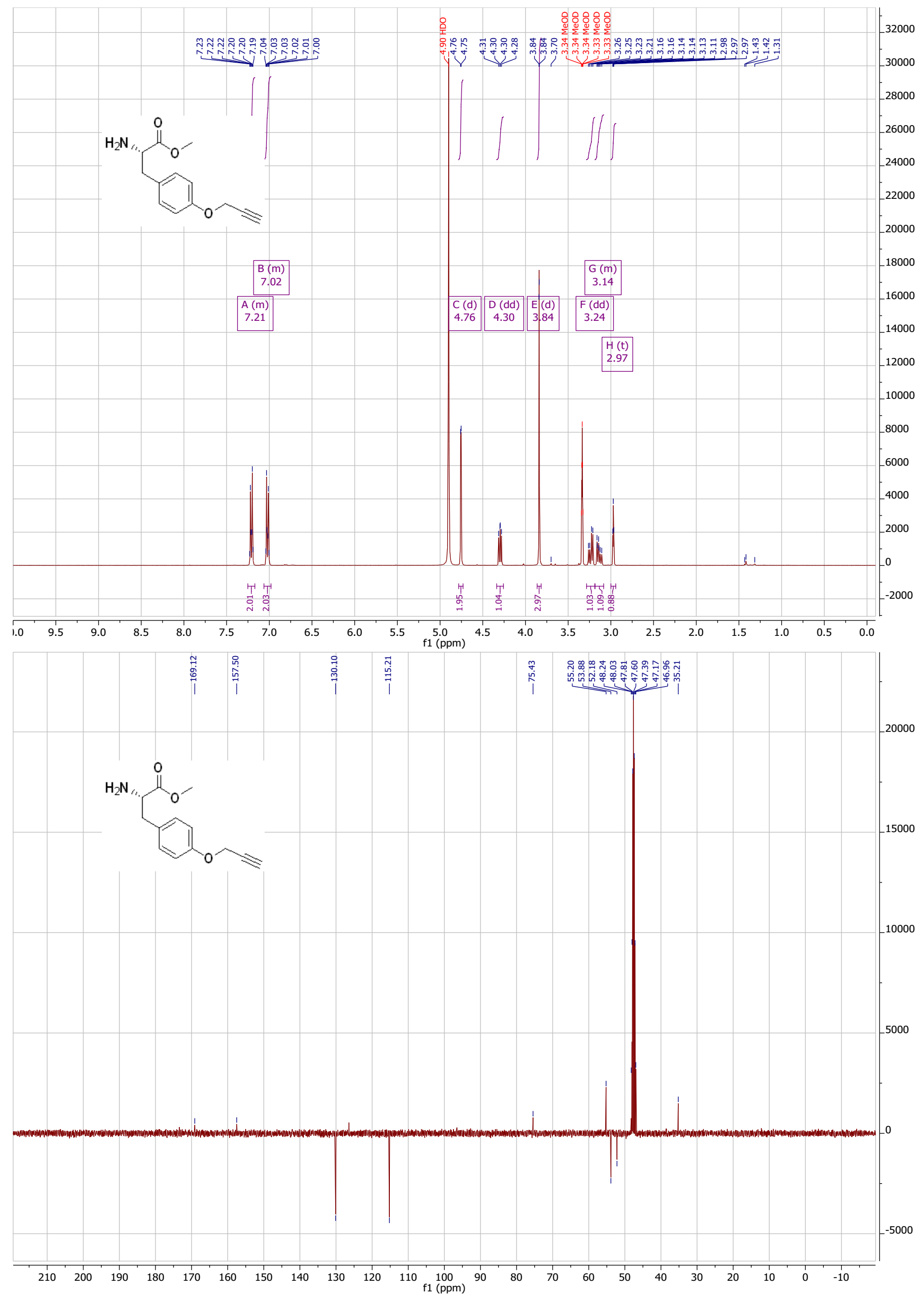




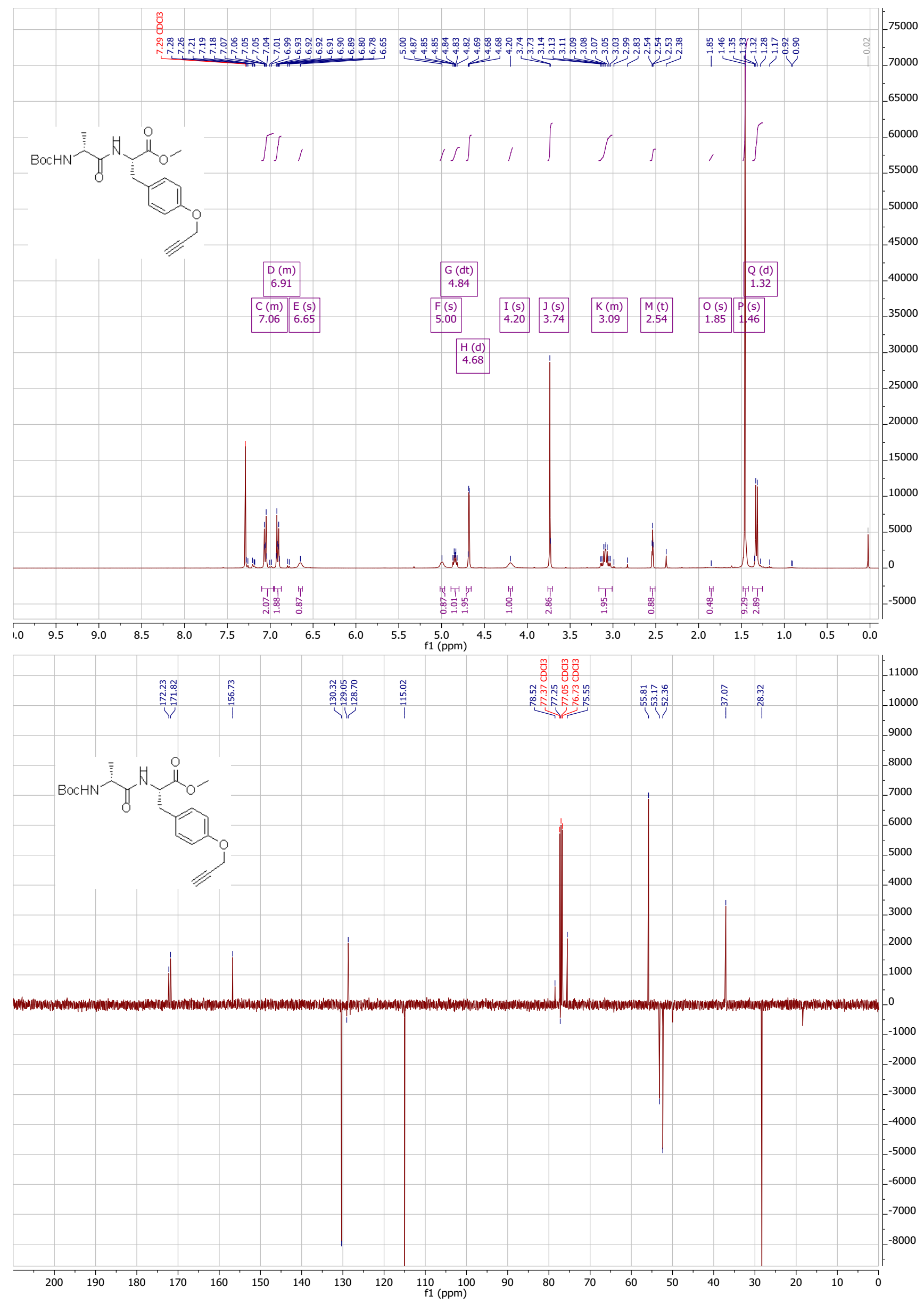




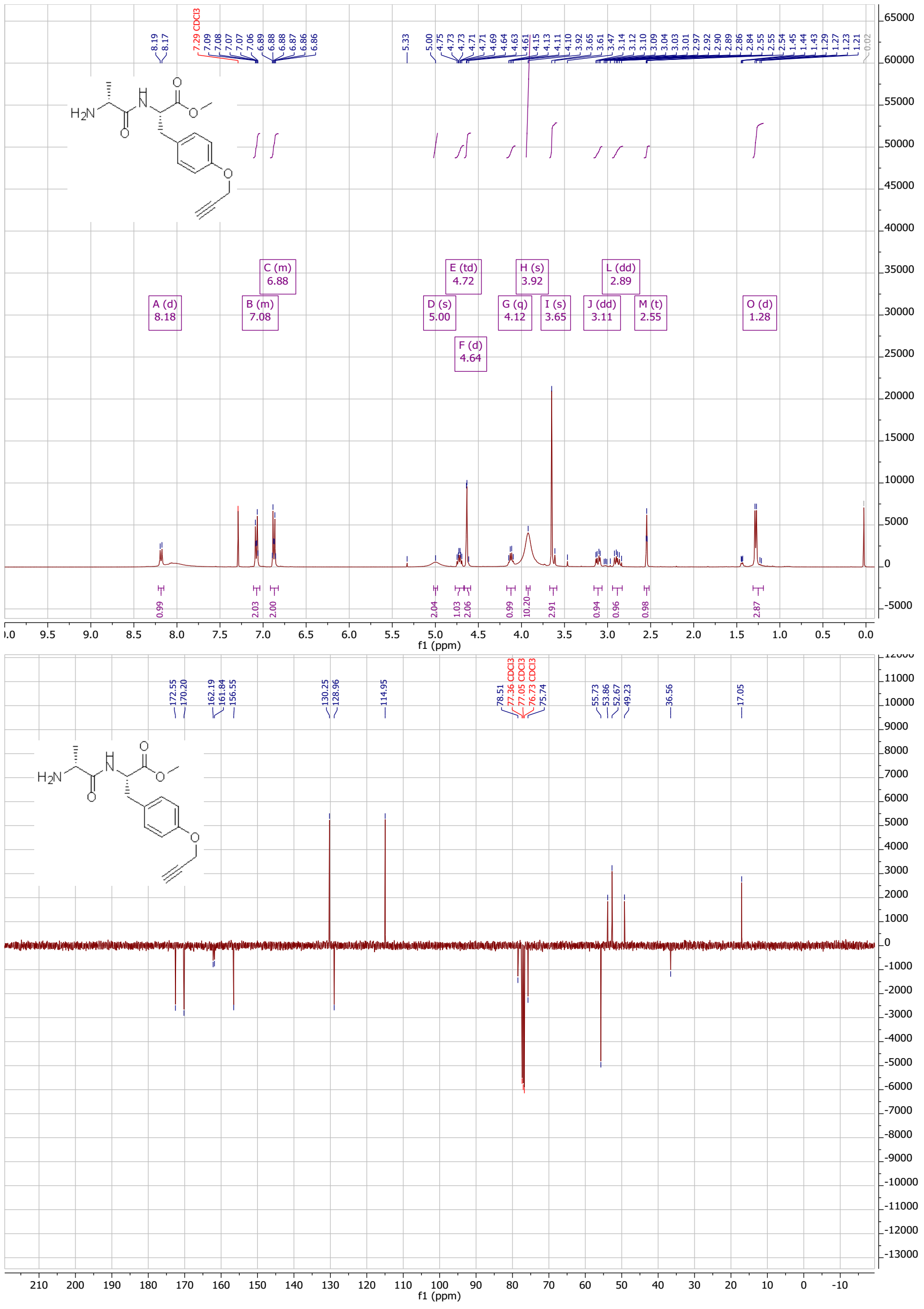




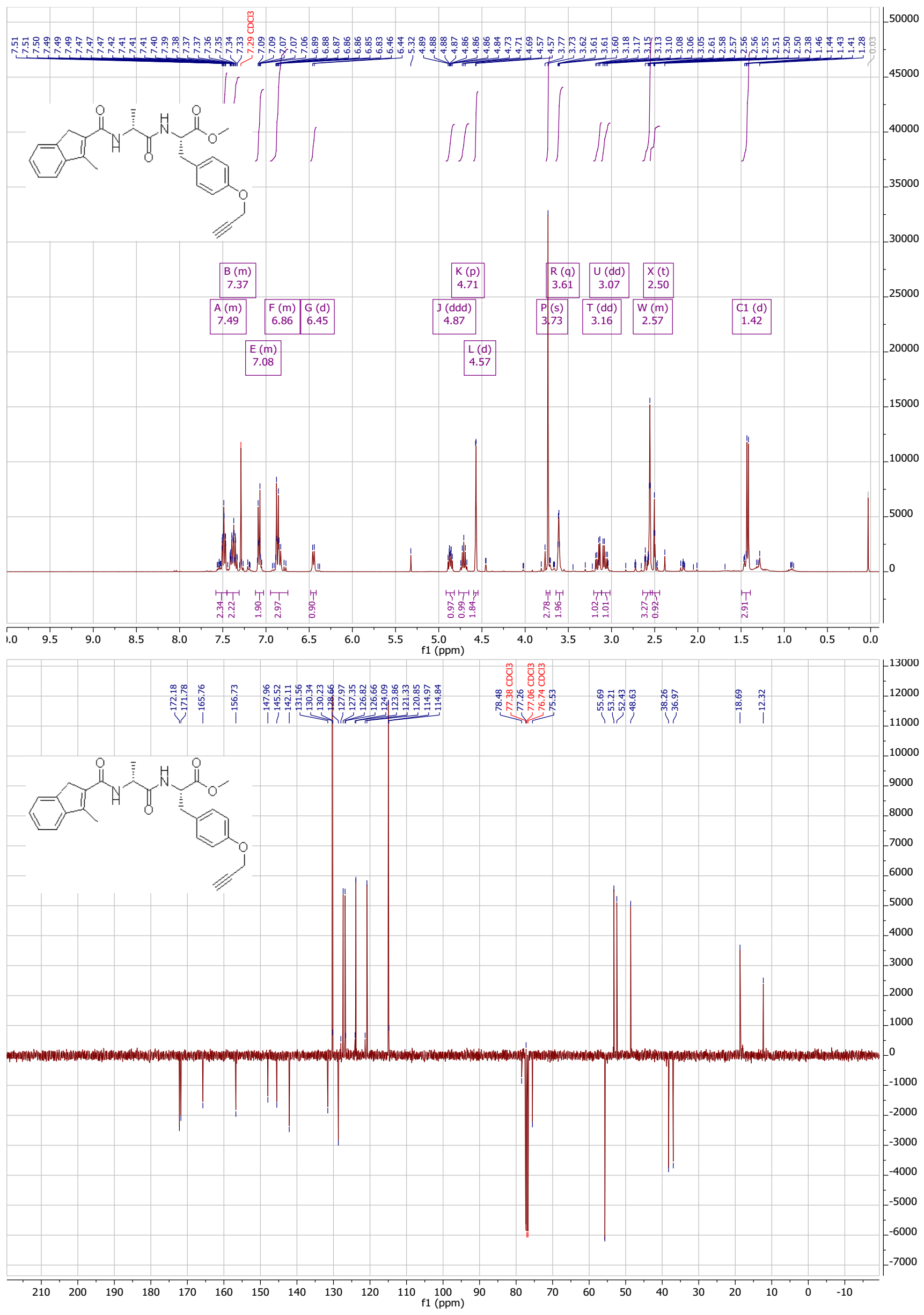




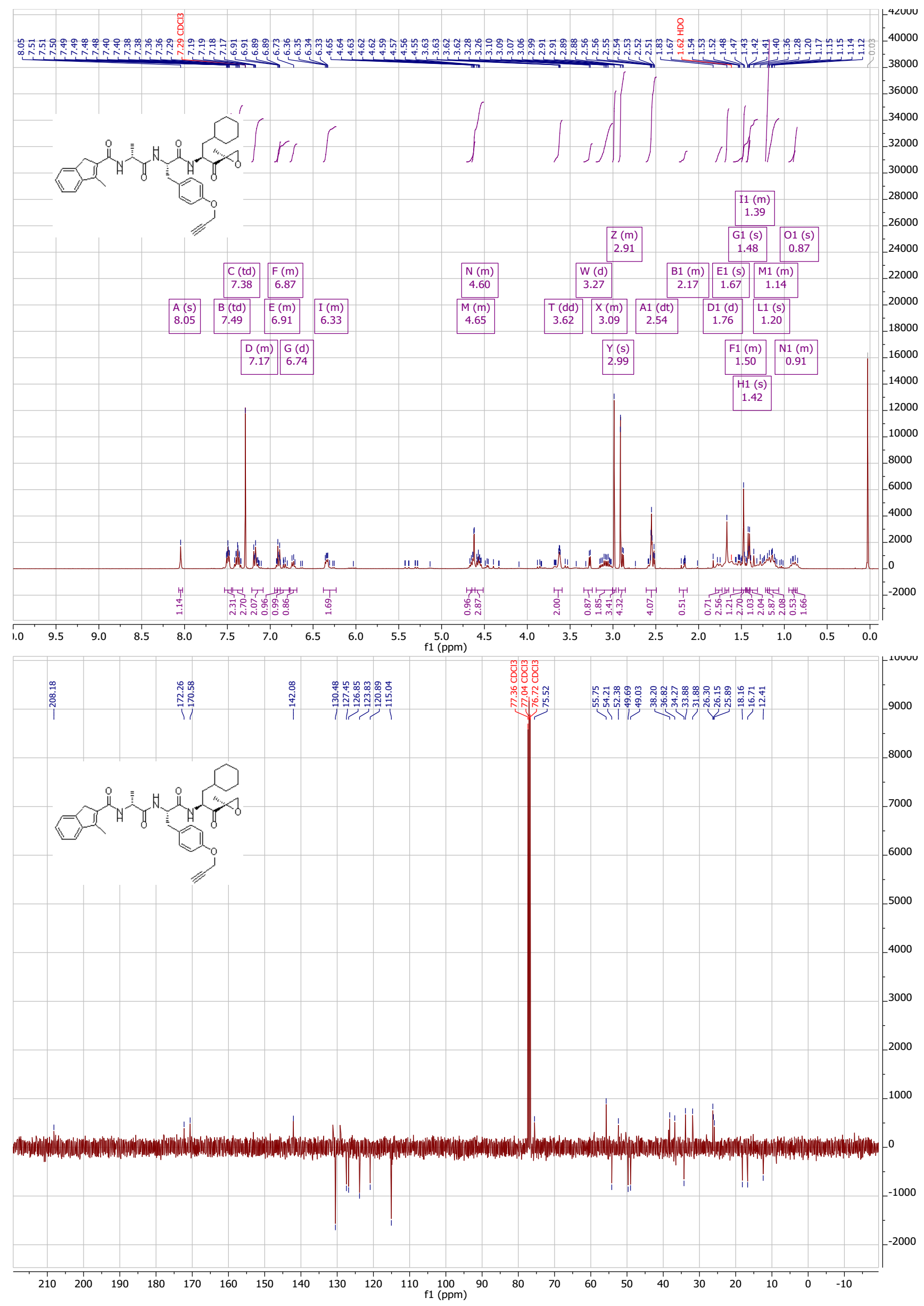




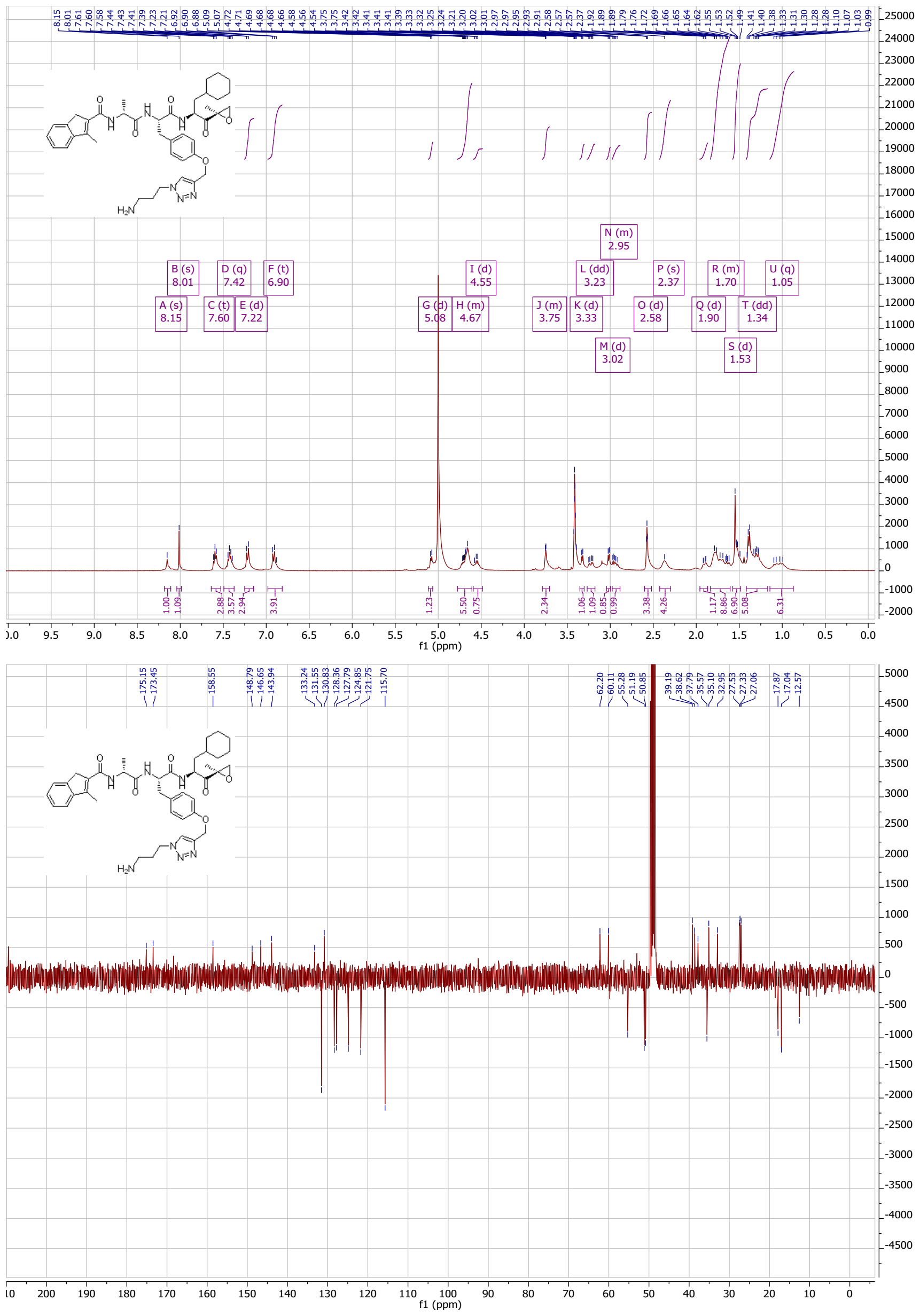




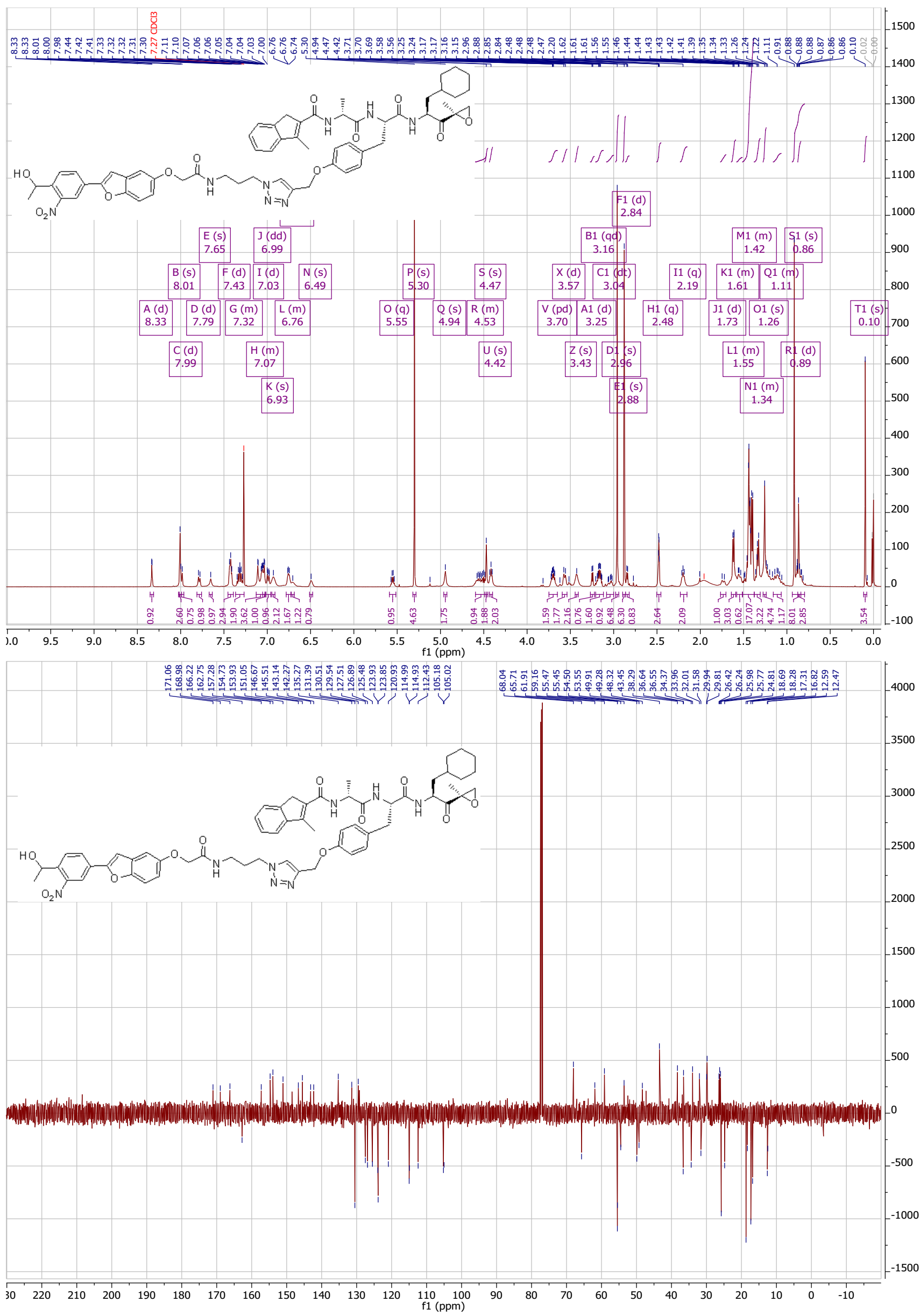




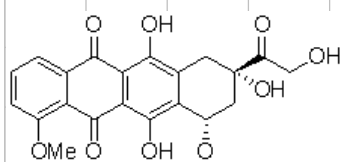

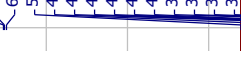

OM

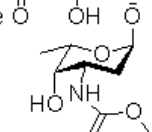

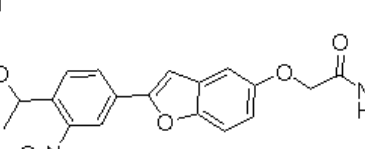<smiles>CCC(=O)NCCCN1CCCC1</smiles>

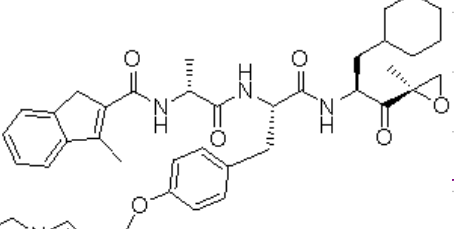

促
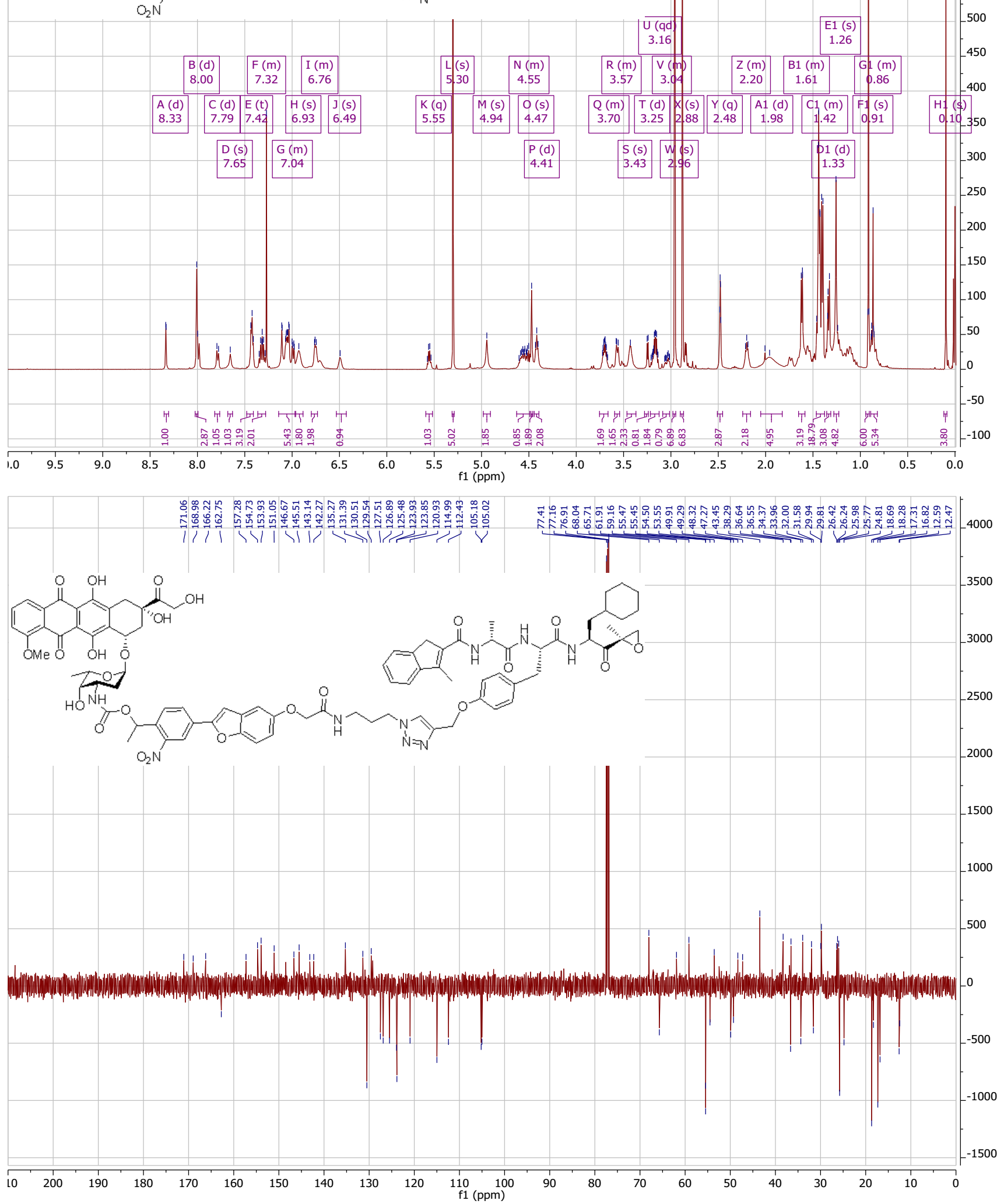


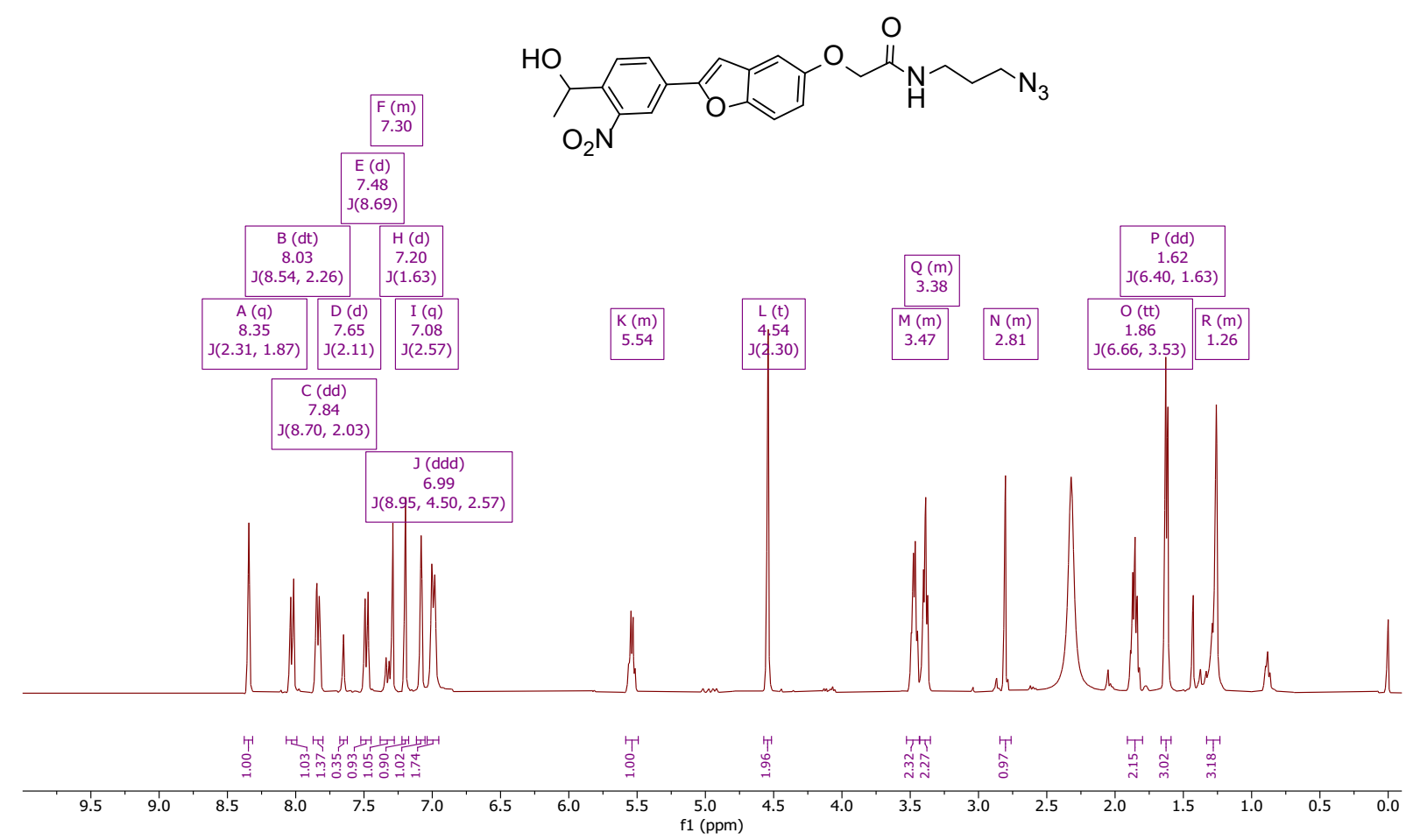

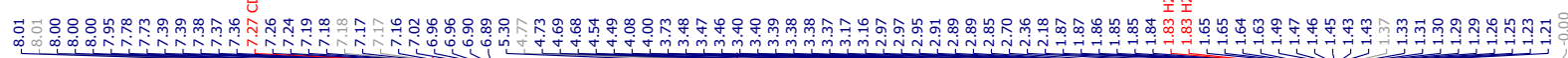

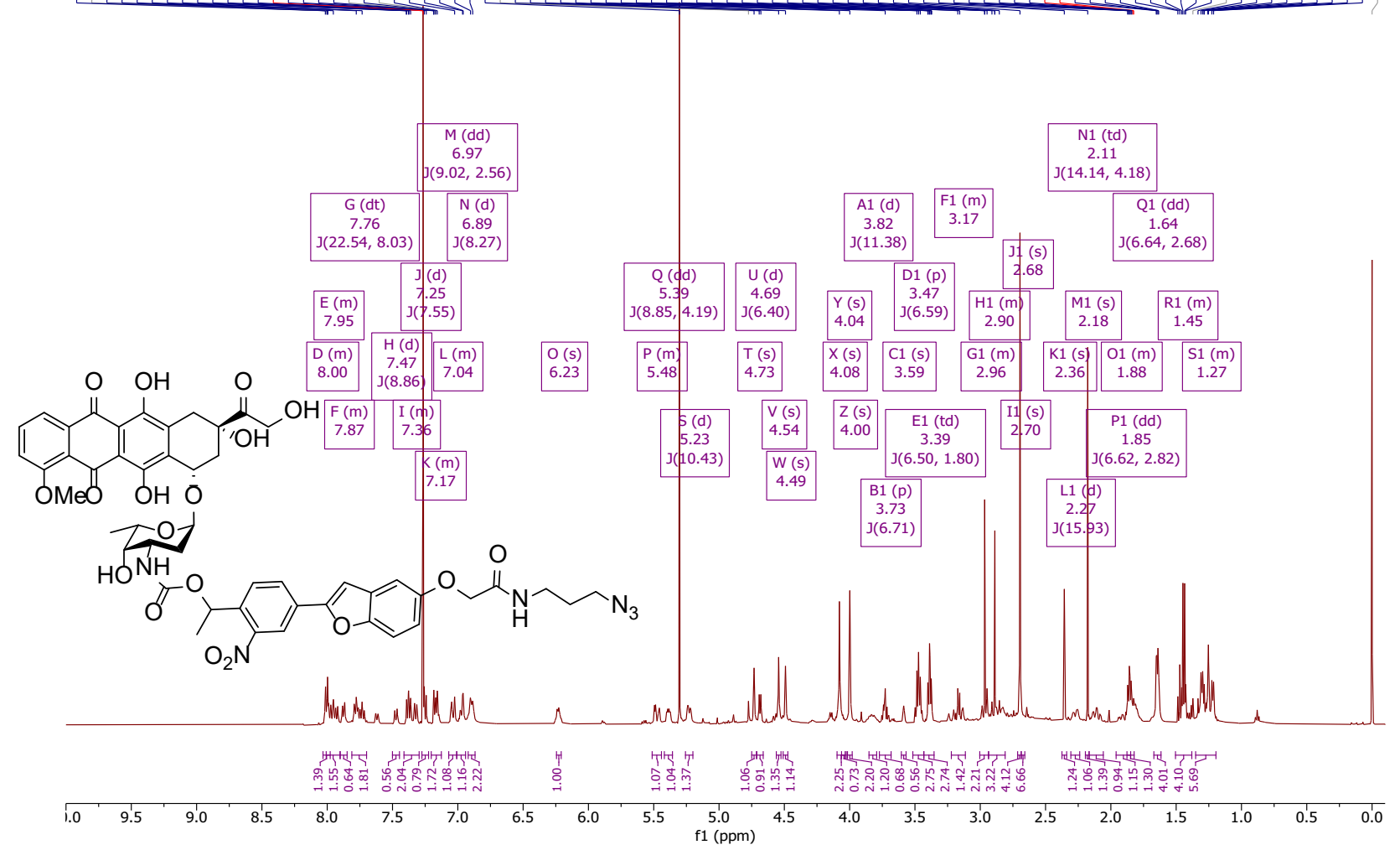


6. LC-MS spectra

MResearchDatal.i.ISontinalSMO15HPLC

RT: $0.00-13.20$

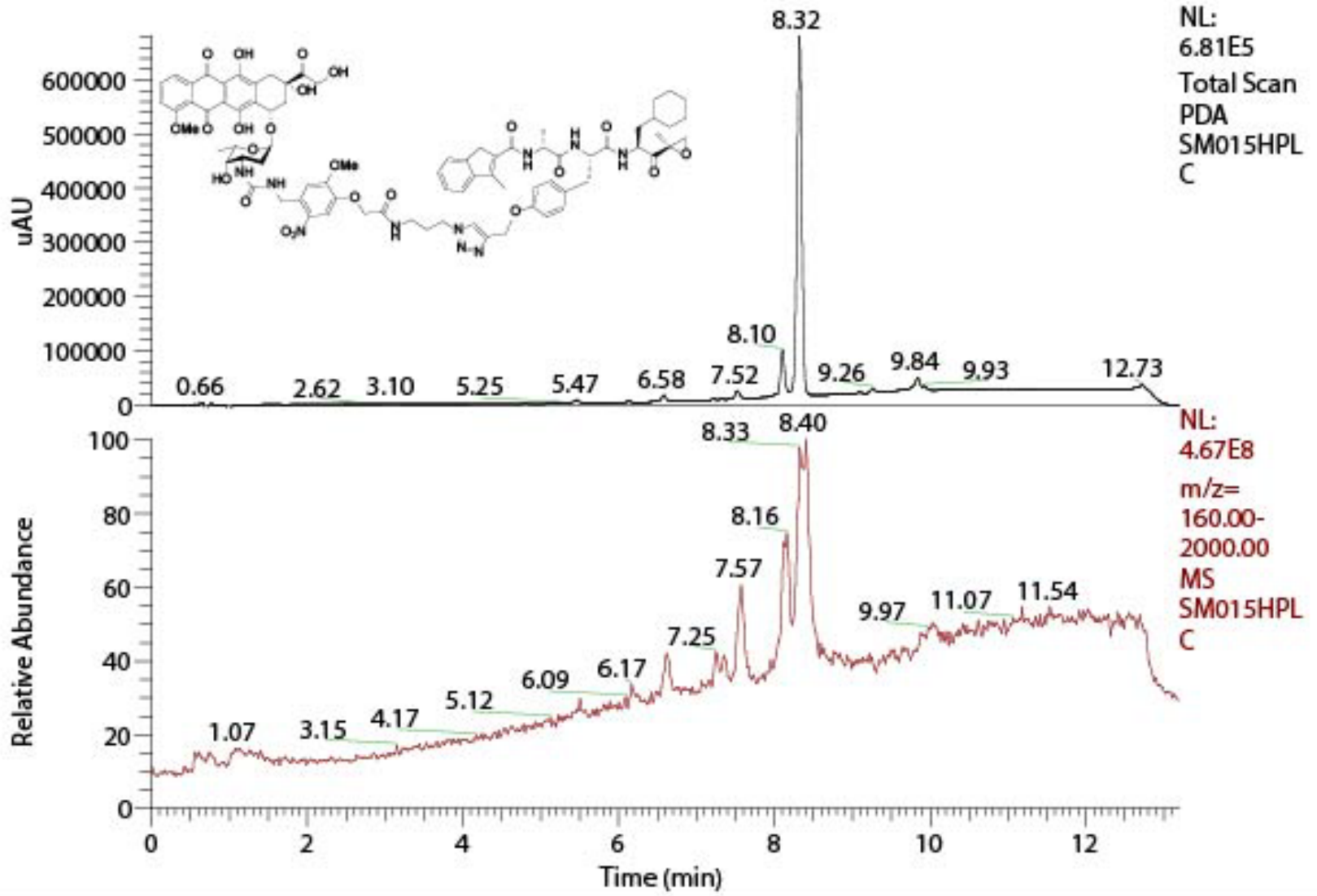

SM015HPLC \#438 RT: 8.36 AV: 1 NL: $6.95 E 6$

$\mathrm{T}:+\mathrm{pESI}$ Full ms [160.00-2000.00]

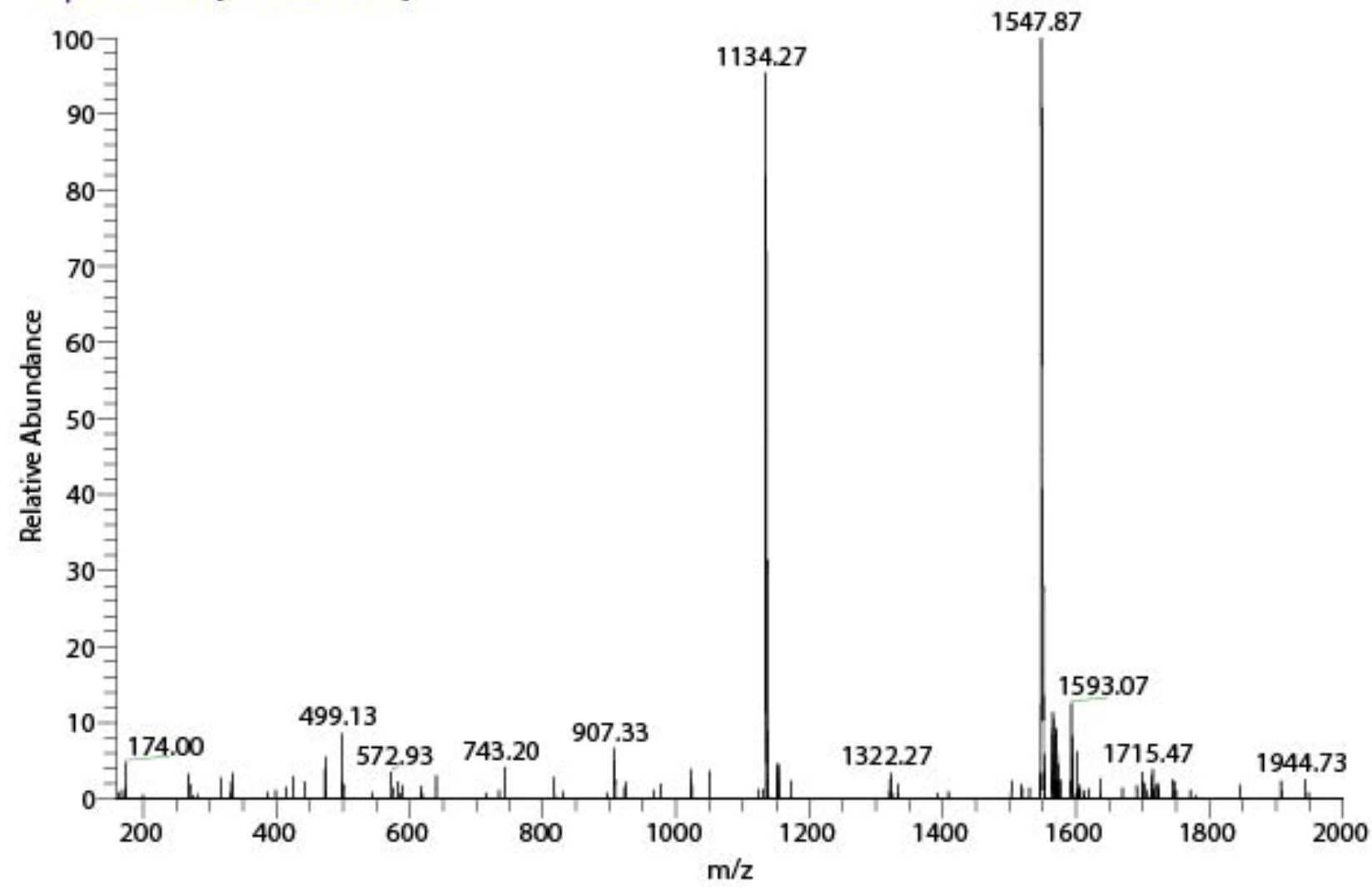


RT: $0.00-13.20$

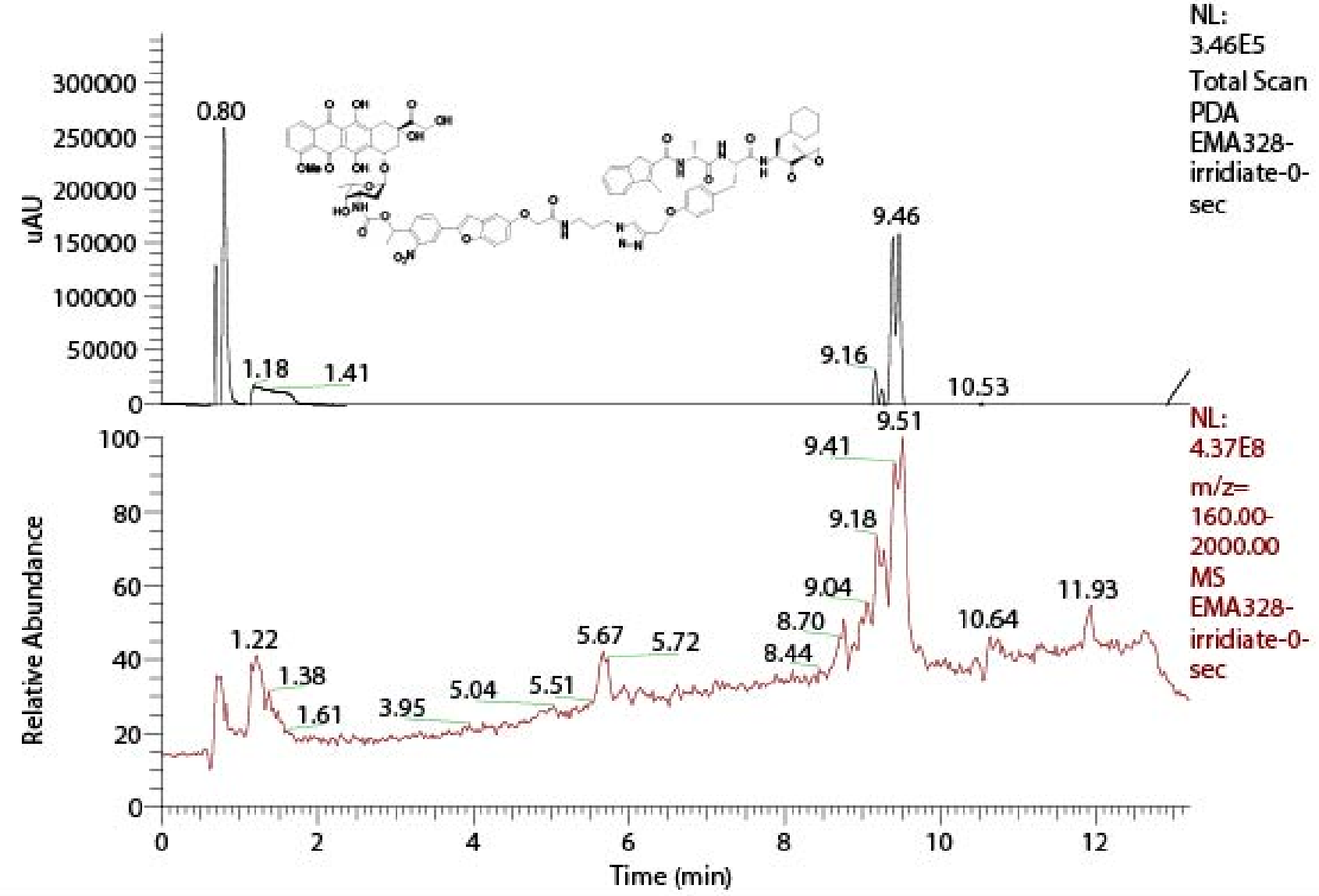

EMA328-irridiate-0-sec \#354-365 RT: 9.33-9.62 AV: 12 NL: 2.95E6

T: + pESI Full ms [160.00-2000.00]

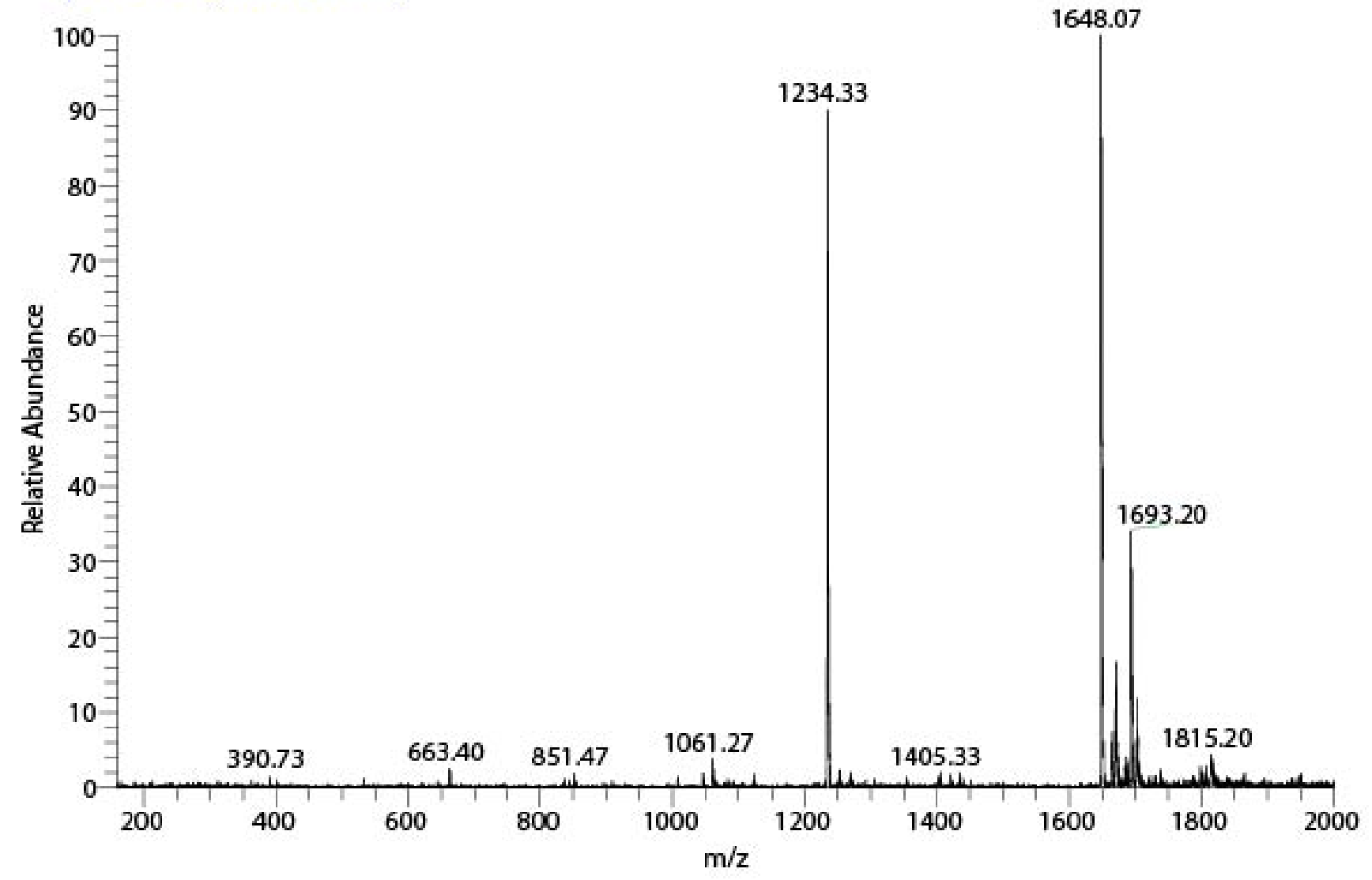




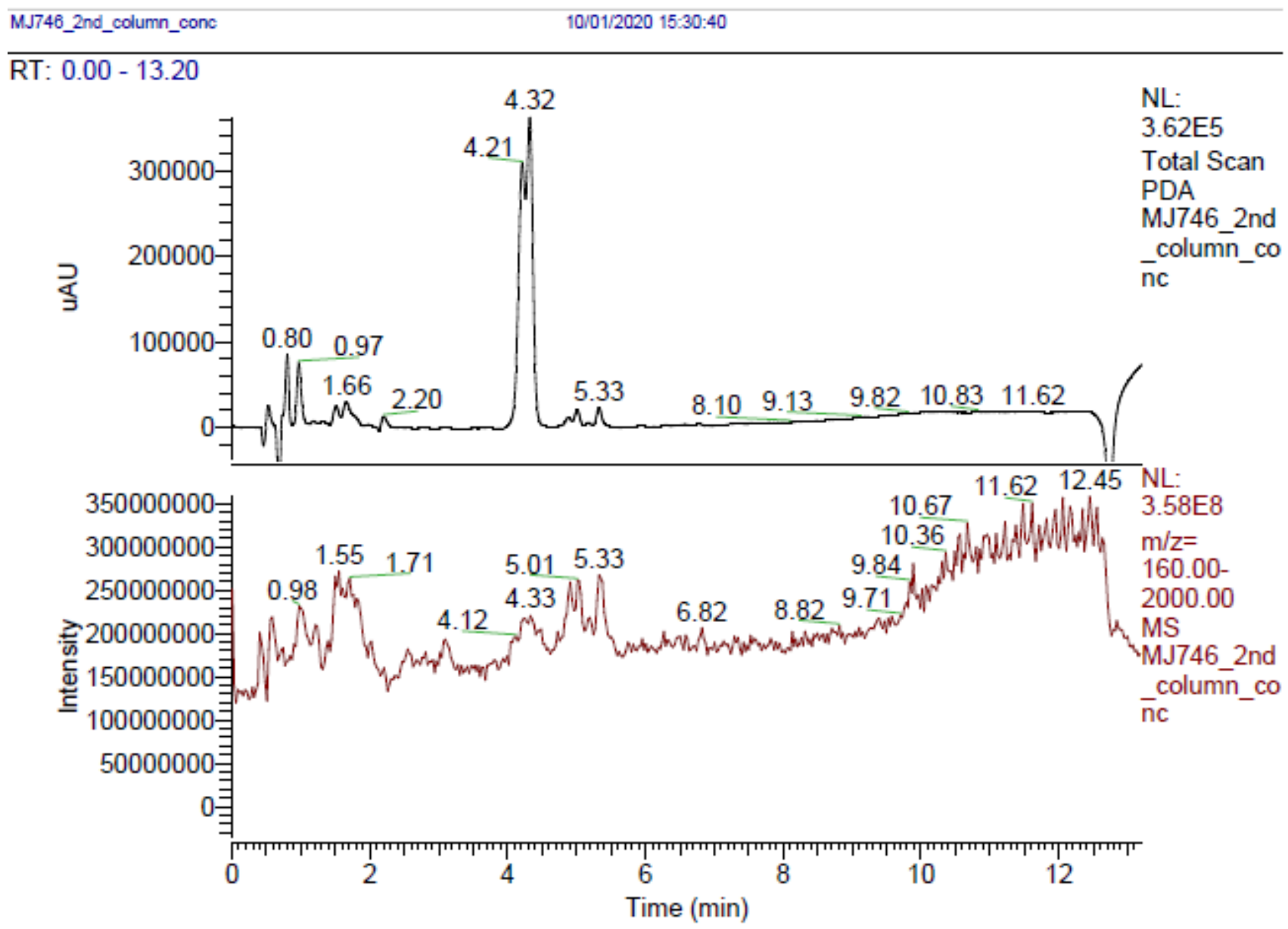

MJ746_2nd_column_conc \#158-168 RT: 4.12-4.38 AV: $11 \quad$ NL: 2.03E6

T: + p ESI Full ms [160.00-2000.00]

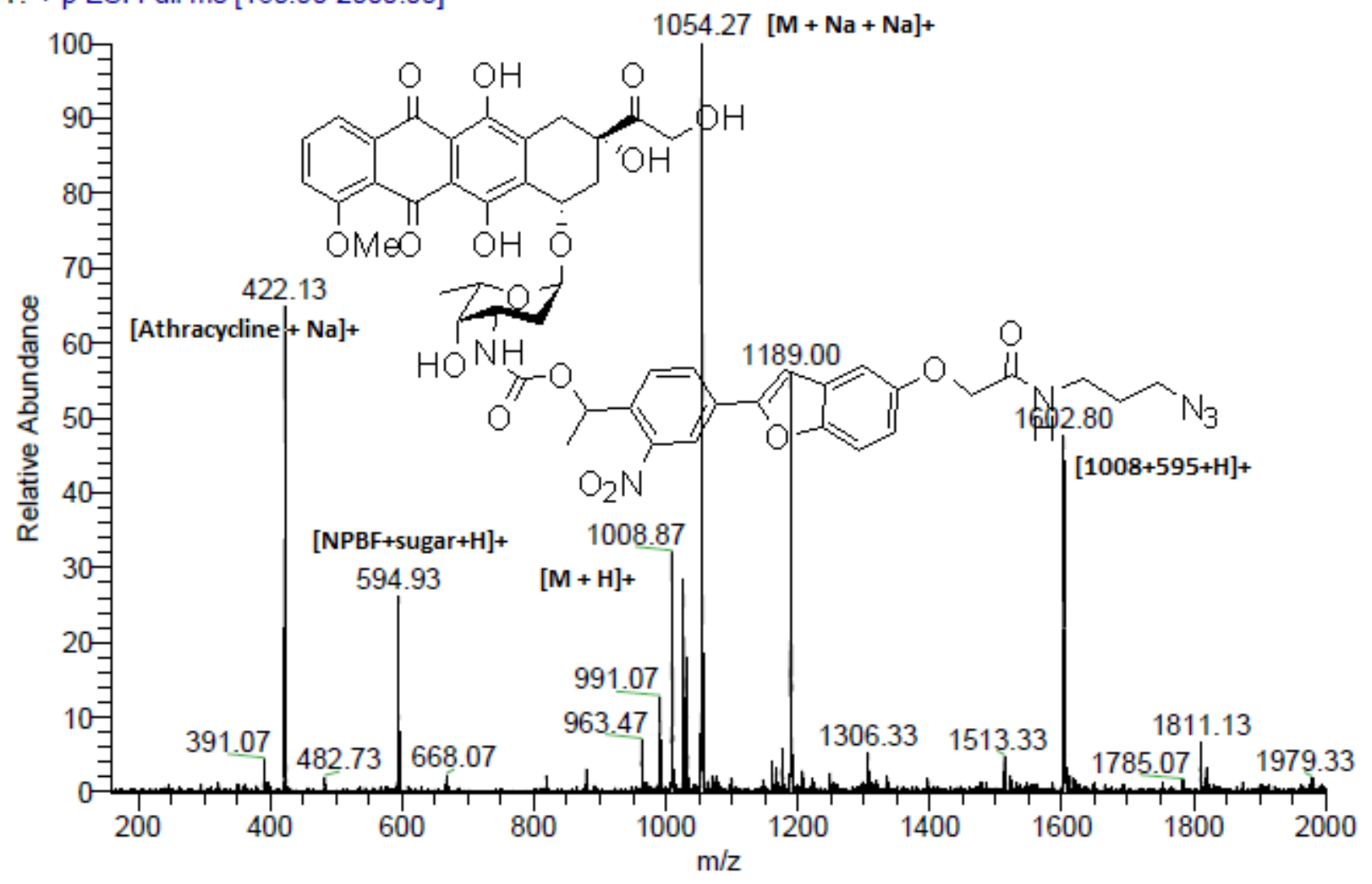

